\title{
A Cultura Cerâmica do Tronco Tupí no alto Ji-Paraná, Rondônia, Brasil: Algumas Reflexões Teóricas, Hipotéticas e Conclusivas
}

Eurico Theofilo Miller ${ }^{1}$

\section{Resumo}

Em 1969, foi reconhecido o vínculo etno-histórico e linguístico dos falantes Tupí-Guaraní com a cerâmica arqueológica correlata da Faixa Costeira, a qual foi denominada de Tupíguaraní. Desde 1958, a "terra natal" do Tronco Tupí foi proposta como tendo sido a mesopotâmia Guaporé-Madeira e Aripuanã (Rodrigues 1958a,1964), por conter seis das suas dez famílias linguísticas (Rodrigues 1986). Em 1913, a Missão Rondon encontrou falantes de línguas Tupí-Guaraní e suas malocas no alto rio Ji-Paraná, RO. Desde 1974 temos estado in loco, testando teórica e empiricamente essa hipótese, com o PROPA 1974-7/ MT-RO, o PRONAPABA 1978-83/RO-AM, o GERO, a Eletronorte e o CNEC. Além da cerâmica corrugada e pintada e de urnas funerárias tão antigas quanto a "terra natal", há lá outros atributos do tipo Tupíguaraní. O mesmo vínculo entre dados arqueológicos, etnohistóricos e linguísticos encontrado na Faixa Costeira foi testado na "terra natal" do ProtoTupí e do Proto-Tupí-Guaraní, tendo resultado na mesma correlação. A busca empírica pela "terra natal" do tronco Tupí chegou até ao seu miolo, através da correlação entre os dados da arqueologia de campo, datações 14C, linguística histórica e fontes etno-históricas.

Palavras-chave: arqueologia, linguística histórica, Prototupí, Proto-Tupíguaraní, Alto-Jiparaná.

\begin{abstract}
In 1969 the ethno-historical and linguistic link of Tupí-Guaraní speakers to the related archaeological ceramics of the Brazilian Coastline was recognized and named Tupíguaraní. Since 1958, the native land of the Tupí linguistic stock is considered to be the area between the Guaporé-Madeira and Aripuanã rivers (Rodrigues 1958a, 1964), for containing six of its ten linguistic families (Rodrigues 1986). In 1913 Tupí-Guaraní speakers and settlements were met by the Rondon Mission on the high Ji-Paraná river, RO. Since 1974 we have been "in loco" testing this hypothesis theoretically and empirically with PROPA 1974-7/MT-RO, PRONAPABA 1978-83/RO-AM, GERO, Eletronorte, and CNEC. Besides corrugated and painted ceramics and burial urns as old as the native land, there are other characteristics of the Tupíguaraní type. The same association of archeological, ethno-historical, and linguistic data acknowledged on the Coastline was tested on the Tupían native land, yielding the same correlation. The empirical search for the native land of the Tupí branch reached its core through the correlation between the data provided by field archaeology, carbon datings, linguistics, and ethnic-historical sources.
\end{abstract}

Keywords: archaeology, historical linguistics, Proto-Tupí, Proto-Tupíguaraní, Alto-Jiparaná.

${ }^{1}$ Eletronorte. 


\section{Esclarecimentos preliminares}

1 - A tradição Tupíguaraní representa a cultura material dos falantes de línguas Tupí-Guaraní da Faixa Costeira (Brochado et al. 1969, Chmyz 1969, 1976).

Este trabalho trata do Prototupí arqueológico e do Proto-Tupí linguístico, originados na mesopotâmia Guaporé-Madeira e Aripuanã, donde se teriam derivado dez protolínguas e dez tradições arqueológicas das quais presentemente se destacam a tradição Proto-Arikém, pela precocidade da agricultura e terra preta desde $5.210 \pm 70$ a.P. em relação à respectiva cerâmica presente apenas aos $2.500 \pm 90$ a.P., e a tradição Proto-Tupíguaraní, pela cerâmica corrugada e pintada desde os 5.070 \pm 60 a.P., da qual derivou a tradição Tupíguaraní da Faixa Costeira; e então pelas tradições Proto-Tuparí e Proto-Mondé. Essas tradições dizem respeito, cronológica e culturalmente, ao 3o e último estágio de sua formação, no qual cada tradição ingressou, simultaneamente, com exceção da Proto-Arikém (ver as duas datações), como caçador-agricultor-ceramista, que abrange de ca. 5.070土60 a.P. até, pelo menos, 1.938 A.D. (Lévi-Strauss [1955]1996), todas assentadas em aldeias semi-sedentárias, demarcadas por terras mais ou menos pretas. Nos primórdios, esse estágio esteve localizado e restrito à mesopotâmia GuaporéMadeira e Aripuanã, que Rodrigues denominou "terra natal" (1958a 1964), mas ocorreu que algumas tradições ultrapassaram-na e distribuíram-se além dela. Na formação do nome para esse estágio antepomos o termo Proto- como diferencial no tempo, no espaço, na tecnologia, etc.

2 - O tipo "Corrugado Complicado" (Chmyz 1966, Pr. 11, n. ${ }^{\circ}$ s 1 e 2), que sob a mesma definição tem sido utilizado comumente como Corrugado, assim também o é neste trabalho (fig. 7, 8 11, 14 e 15).

3 - O tipo "Pintado" da terminologia de Chmyz (1966) está presente no Proto-Tupíguaraní; inclusive o tipo pintado sobre superficie simples alisada, como o denominamos (raro ou inexistente no Tupíguaraní).

\section{Introdução}

Em atendimento ao convite dos organizadores do II Encontro Internacional sobre Línguas e Culturas dos Povos Tupí, UnB, 1-3/10/2007, apresentamos este trabalho, o qual pretende ser uma constatação sobre o Prototupí (denominação arqueológica diferencial). Baseia-se nas evidências cerâmicas existentes desde ca. 5.070 60 anos a.P., que levam às correlações entre os resultados arqueológicos, cronológicos, linguísticos e etno-históricos 
de Rondônia e estados limítrofes. Elas são concordantes, em grande parte, com a hipótese de Aryon Dall'Igna Rodrigues (1958, 1964, 1986). A arqueologia, com base principalmente nos tipos cerâmicos, além de sugerir a ocorrência de desenvolvimento diferenciado entre as 10 famílias linguísticas, sugere que essa diferenciação se estendeu aos seus subgrupos, dentro de cada família. Essas diferenciações correspondem a movimentos (divisões, separações e dispersões) de magnitudes e intensidades diversas. Então, segundo as evidências arqueológicas, o Proto-Tupíguaraní, em termos da cerâmica, tem a datação de ca. $5.070 \pm 60$ a.P. segundo o ${ }^{14} \mathrm{C}$ (fig. 29, coluna 4). Segundo a reconstrução linguística (Rodrigues 1958a) todas as demais famílias do tronco Tupí, exceto a Arikém, mostram evidência do conhecimento da cerâmica na mesma época, e, segundo as evidências agrícolas (fase Massangana), o Proto-Tupíarikém foi o mais precoce em relação aos demais em termos de agricultura, surgida há ca. $5.210 \pm 70$ a.P. segundo o ${ }^{14} \mathrm{C}$ (fig. 29, coluna 6), mas a sua cerâmica (tradição Jamari) só surgiu ca. 2.700 anos depois, aos ca. $2.500 \pm 90$ a.P. (Miller et al. 1992). A fase Massangana hipoteticamente surgiu entre ca. 6.000 a 5.000 a.P. da fase Pacatuba de caçadores-coletores PréPrototupí (fig. 29, coluna 6). Dessa forma, a tradição Prototupí tem passado por reavaliações desde as datações de 2001 e continua assim, visto que as datações que a suportam ainda são poucas. Mas aos poucos as dúvidas cedem lugar à certeza, confirmando a datação da Proto-Tupíguaraní, em especial, na Área Alto-Jiparaná. E suas expansões, migrações e dispersões mais antigas para o Paraguai, noroeste da Argentina ca. 2.700 a.P. (Dougherty com. pes., Meggers \& Evans 1973:58), para o sul do Brasil com possível presença no alto rio Uruguai, Rio Grande do Sul, a ca. 4.000 a.P. (Miller 1969a, 1971), e no sudeste-sul da Faixa Costeira, denominada de Tupíguaraní.

Daí depreendemos que o fenômeno formador principal do $3^{\circ}$ estágio é a agricultura, por estar ela presente ao longo deste estágio e atestada pela terra

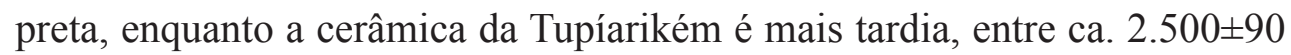
a.P., de acordo com a tradição Jamari cerâmica (Miller et al. 1992) (fig.29, coluna 6).

Portanto, a arqueologia Prototupí tem agricultura e cerâmica desde ca. $5.070 \pm 60$ a.P, enquanto que a arqueologia Tupíarikém da família linguística Arikém tem só a agricultura desde $5.210 \pm 70$ do final do $2^{\circ}$ estágio (fase Massangana) até o final do $1^{\circ}$ subestágio do $3^{\circ}$ estágio ca. 2.750 770 . Mas a agricultura juntamente com a cerâmica ocorre no $2^{\circ}$ subestágio do $3^{\circ}$ estágio, entre ca. 2.500 a.P. e A.D. 1.720. Os dois subestágios têm ca. 2.500 anos cada um, tendo intercalada uma fase intermitente de semi-aridez suave ao longo de ca. 250 anos. 
Em relação à arqueologia Tupítuparí da família linguística Tuparí, e Tupímondé do subgrupo Paitér da família linguística Mondé, como se desenrolará o $3^{\circ}$ estágio? Estão lado a lado com a Protokawahíb, a Tupímondé a oriente e a Tupítuparí a ocidente. Mas, segundo a linguística, com a reconstituição de termos desenvolvida por Rodrigues (2010 no prelo), a agricultura e a cerâmica já eram conhecidas desde o início do $3^{\circ}$ estágio, ca. 5.000 a.P.

Outra questão extremamente importante, que precisa de nossa atenção e muita pesquisa de campo, diz respeito à pintura. No vasilhame da área Kawahíb a pintura está presente desde ca. 5.070 a.P. A superfície com engobo branco está pintada com vermelho e a engobada ou banhada de vermelho tem pintura branca; e só nesta ocorrem pinturas em branco ou preto sobre superfície simples alisada, não se sabendo ainda se ao longo de todo o $3^{\circ}$ estágio. Para a cerâmica pintada da área Mundurukú e da área Tupínambá, as respectivas localizações originais, bem como as características das mesmas, ainda são desconhecidas. Porém, fora da terra natal, as duas são conhecidas, a Tupínambá bem mais, ao longo do suestenorte da Faixa Costeira, e a Tupímundurukú, bem menos conhecida além de algum vasilhame; ainda não existem pesquisas arqueológicas entre o baixo Madeira, a jusante do Aripuanã, e o Tapajós. As três existem: estas duas, Tupíguaraní e Mundurukú, seriam de dois subgrupos separados do terceiro, que seria o da Proto-Tupíguaraní, o único com cerâmica pintada e corrugada na Área Alto-Jamarí até a chegada da Missão Rondon em 19091915. A Proto-Tupínambá teria se separado e migrado o mais tardar em meados do $1^{\circ}$ subestágio do $3^{\circ}$ estágio, na $3^{\mathrm{a}}$ fase, sob a expansão e pressão demográfica em ca. 3.800-3.700 a.P. (fig. 29, coluna 4, $3^{\text {a }}$ Fase) - mas de que parte da "terra natal"? Essas questões acima sumarizadas e outras serão tratadas com mais detalhes a seguir e dentro do possível.

Arqueologicamente, em princípios da década de 1980 já considerávamos a proposta linguística de Rodrigues mais uma realidade, testada e validada, mais um fato linguístico e arqueológico, do que apenas uma hipótese linguística isolada (Miller 1983a, 1983b: 272-288), apenas esperando o apoio de datações ${ }^{14} \mathrm{C}$, agora apresentadas neste trabalho (fig. 29, periodização). Essa demora, avaliamos, se deveu à falta de um programa específico dedicado ao aqui proposto Prototupí, várias vezes sugerido, para identificar, pesquisar e concluir, similarmente ao da Faixa Costeira, como agora finalmente está ocorrendo, graças à oportunidade oferecida pelo encontro acima mencionado. 


\section{Do meio ambiente histórico (de 1500 A.D. ao presente)}

Ao longo de séculos, a paisagem do espaço Amazônico foi considerada pouco mais que simples prolongamento da calha do rio Amazonas, onde prevalecia o senso comum. Exceção para a porção meridional que, considerando a linha do Equador, compreende no mínimo quatro quintos da Amazônia incluindo o rio Amazonas, toda a floresta equatorial e quase toda a tropical úmida, de ambas as margens. Portanto, a Amazônia é muito mais hemisfério Sul do que hemisfério Norte. O Pico da Neblina está muito mais perto da Linha do Equador do que a cidade de Manaus.

O norte do Sudoeste da Amazônia, tomado como sendo a confluência do rio Madeira com o rio Amazonas ao norte, situa-se aos $3^{0} 20^{\prime}$ Lat.S. Seu ambiente com expansão em leque para o sul experimenta, com as estiagens, temperaturas de até $0^{\circ} \mathrm{C}$, com vários choques hipotérmicos, de três dias. Ocorrem chuvas de granizo; as aves migratórias congelam e sucumbem à noite, devido aos fortes ventos oriundos do sul da Patagônia, que chegam até Manaus e à Linha do Equador já bem abrandados. Aí, no sul do Sudoeste Amazônico ocorrem altas planícies e depressões de inundação (120-180 m.a.n.m.m.), como os Llanos de Mojos, a Planície, a Depressão e o Pantanal do Guaporé, tendo os rios Mamoré, Guaporé e outros de permeio. Ao leste destes, ocorre a encosta florestada regada por fontes de águas subterrâneas do Chapadão dos Parecis (Refúgio Guaporé) e a Serrania de Ricardo Franco e Capurús com 1.078 m.a.n.m.m. A tônica são as florestas mistas, "perenes", mas semi-caducifólias, interdigitadas em meio às planícies altas dos contrafortes florestados dos Andes e o Chapadão dos Parecis, ponteado de colinas e sumidouros, que escondem cemitérios pré-históricos decorados com arte rupestre, ainda inexplorados. A altiplanura com ca. 600 m.a.n.m.m. em Vilhena, RO, pende em suave declive para a calha do rio Amazonas; vai sendo carcomida pela erosão flúvio-pluvial, formando as calhas dos rios JiParaná, Aripuanã, Juruena, etc., com campos sujos ao norte, savanas ao sul e leste, com matas de galeria ao longo do emaranhado fluvial nascente, que vão alimentando, coalescendo e traçando os dosséis progressivamente mais altos e amplos. A chamada Serra do Norte não é uma serra, é sim o contraforte do esboroamento da encosta do Planalto, resultando nessa impressão inicial.

\subsection{Dos tipos de clima}

Fig. 3-A. (Köppen), desde o Refúgio Rondônia-Aripuanã, coincidente com a "terra natal" do Tronco Tupí e Tradição Prototupí: (1), Am, quente 
com curta estação seca; Aw, sobre o divisor Guaporé-Paraguai; (2), quente com semestre de inverno seco; Cwa e Cwb, respectivamente a leste e oeste do Pantanal do Paraguai; (3), tropical de altitude, com semestre de inverno seco e verão quente (Brasil) e verão brando (Bolívia); Cfa e Cfb, respectivamente no extremo sul da Faixa Costeira e na porção mediana do sul da Faixa Costeira; (4), subtropical com chuvas bem distribuídas, com verão quente (RS), e com verão brando (SC, PR e SP) (adaptado de: Houaiss 1981; BRASIL.CNG $1966,1977 b, c, d$.

\subsection{Dos tipos de vegetação}

Fig. 3-B. Mesmo espaço físico de 3A. (1) Fpa, Floresta perenifólia Amazônica; Fsa, Floresta subcaducifólia amazônica; Fst, Floresta subcaducifólia tropical; Ct, Campo tropical; S, Savana; CP, Complexo do Pantanal;Fss,Floresta subcaducifólia subtropical;FSa,Floresta subcaducifólia subtropical com Araucaria angustifolia; Fpc, Floresta perenifólia costeira; SC, Savana do norte do Chaco; Pi, Pântano inundável; MxC Mata xerófila do Chaco; Cs, Campo subtropical e temperado; Fta. Floresta tropical andina; Eax, Estepe, arbustos xerófilos; Ea, Estepe árida (adaptado de: Houaiss, 1981; BRASIL.CNG, 1966; 1977b; c; d.).

Passados 33 anos desde 1974, o que então era coberto por florestas secundárias milenares e seculares (visto que a intensa e extensa ocupação Tupí deve ter reduzido a floresta primária a uma exceção e não mais a uma regra - e a onipresença da mandioca selvagem parece corroborar essa impressão) hoje é quase só agropecuária no Alto-Jiparaná, com pequenas áreas isoladas como relicto do meio ambiente secundário original. Dos mais significativos indicadores vegetais, quanto à boa qualidade do solo para a agricultura, que atraiu e adensou os sítios Prototupí desde ca. 5.210-5.070 a.P. e os atuais colonizadores brasileiros, pouco restou: trata-se da palmeira urucurí (Attalea excelsa). É comum ao longo das estradas a visão da mandioca selvagem, talvez um relicto da primitiva agricultura dos Prototupí e seus descendentes, e demais famílias e troncos linguísticos não-Tupí.

\section{Do meio ambiente pré-histórico}

A noção do meio ambiente histórico é útil para o final da história do Proto-Tupí na "terra natal” de Rodrigues (1958a, 1964, 1986), conhecido muito tardiamente pelos seringueiros no fim do Séc. XIX e pela Comissão Rondon no princípio do séc. XX. Para o entendimento do que vem a 
seguir sobre o meio ambiente pré-histórico da "terra natal arcaica" e o que chamamos de $1^{\circ}$ estágio até o $3^{\circ}$ estágio, esta tentativa de reconstituição é baseada em dados arqueológicos de campo e estratigrafia apresentados nas colunas periódicas da fig. 29 e no texto "Do Pré-Prototupí ao ProtoTupíguaraní” (p. 35 a 39).

Em primeiro, deparamos com um cenário transicional do Pleisto-Holoceno ao Holoceno Inferior, baseados nos dados do paleoindígena ao arcaico, na fig. 29, colunas 1 e 2 e 4 a 6, de Rondônia ao Rio Grande do Sul, numa das rotas provavelmente mais antigas do sudoeste amazônico para o sul Tupí.

Em segundo, fixamo-nos na coluna 4, o centro deste trabalho. Estamos hipoteticamente em 7.000 anos a.P., início do $1^{\circ}$ estágio no Holoceno Médio, e avançando para 6.000 anos a.P. Ao longo desse tempo o clima vai ficando gradativamente mais quente e mais úmido, é o Optimum Climático chegando e impondo-se, provocando a coalescência das florestas abertas com palmeiras, e fazendo surgir outras novas sobre o cerrado/savana e depois sendo reduzidas a relictos, como as atuais. O indígena presente é um caçador-coletor PréProto-Tupí. É organizado e distribuído em bandos e macrobandos na "terra natal arcaica". Vive com mais ou menos caça e coleta de mata, conforme a sazonalidade, conforme as modificações ambientais ao sabor do clima, para uma subsistência que aos poucos aumentará para alguns bandos e macrobandos de caçadores-coletores, em detrimento de outros bandos e macrobandos. $\mathrm{O}$ que os distingue gradativamente, no espaço e no tempo, é uma progressiva diferenciação na cultura material e na língua. Principalmente a disputa pela subsistência leva a pressões territoriais entre esses bandos e macrobandos.

Ao longo dos 6.000 - 5.000 anos a.P., no $2^{\circ}$ estágio, o clima continuou esquentando e umidecendo mais ainda, chegando ao pico do Optimum Climático ca. 5.500 a.P. Estrangulados e sufocados pela floresta perenifoliada restam pequenos testemunhos, relictos da floresta caducifólia descaracterizada e dos cerrados nos litossolos, e muitas capoeiras com predomínio de palmeirais devido às queimadas. O indígena agora presente é o Pré-Prototupí, um caçador-coletor com acampamentos e macroacampamentos, não raro quase aldeias rápidas. Estariam os grupos distanciados uns dos outros, antes cerca de três palmos ou pouco mais de sol, agora, estão mais próximos, no máximo três palmos e com mais famílias, e com menos caça, provocando a invasão do espaço de uns pelos outros. Há dias em que só trazem um caititu (Tayassu pecari) para quatro famílias. Quando caçam uma anta (Tapirus terrestris) é um dia memorável, festa e cantoria. Há matas secundárias seculares, há 
inumeráveis acampamentos indígenas (matas primárias vão rareando), inúmeras vezes reocupadas e abandonadas, frequentadas pela caça e pelo caçador-coletor atrás do pecari (Tayassu tajacu), fuçando as magras raízes da mandioca selvagem de inumeráveis coletas dos bandos indígenas. A caça e a coleta já não preenchem as necessidades de todos e alguns macrobandos, os menos poderosos, aos poucos vão se afastando, se distanciando, pela fome e a impotência; de alguns, os que ficaram há muito não têm notícias (Meggers e Evans, 1973:57). Depois de um milhar de anos na "terra natal arcaica" algumas das mulheres coletoras dos bandos que, no $3^{\circ}$ estágio, serão os falantes do Proto-Tupí começam a notar que os restos mal roídos pelas varas de porcos apresentavam raízes gradativamente mais gordas que a mandioca selvagem corriqueira; e começam a levar as ramas para os macroacampamentos, dando início consciente a uma incerta horticultura arcaica incipiente, da qual elas, as mulheres, não se afastam de todo devido aos animais que podem comê-las. Os macroacampamentos, quase aldeias, aos poucos passam a ser regulados pelas colheitas da agricultura incipiente.

Tirada a cerâmica da tradição Prototupí, resta a terra preta da agricultura (veja a cultura Massangana, Miller et al. 1992, figs. 18, 28 e 29, coluna 6). Tirada a terra preta da agricultura, resta quase nada para indicar a presença do pré-agricultor e pré-ceramista; restarão lascas e núcleos de pedra simples quebrados a esmo, assemelhados àquelas lascas encontradas em meio à terra preta dos sítios-habitação Prototupí da "terra natal" e do Tupíguaraní da Faixa Costeira (figs. 30 e 31).

Por volta dos 5.210 anos a.P., a transição dos caçadores-coletores PréTupí seguida pelo Tupíkawahib do $2^{\circ}$ estágio, aos poucos ingressa no $3^{\circ}$ estágio marcado pelo caçador-coletor agricultor e ceramista, como Tradição Arikém e Tradição Tupíguaraní. É um dos eventos cruciais na evolução cultural e social do homem, mudando completamente a perspectiva de vida do antes simples caçador-coletor. Se a história se imita, essa transição foi gradual, começando pelos melhor situados, junto às corredeiras fluviais, junto às melhores terras para plantio, junto dos urucurizais. Aumentam as aldeias em tamanho e número. Os macroacampamentos abertos estão se transformando em aldeias com malocas de uma só e pequena entrada para o Tupíarikém e, com base nos dados etno-históricos, estranhamente, em ranchos de duas águas com seis esteios e sem paredes para o Proto-Tupíguaraní, no final de sua história (p. 27-31). Os caçadores, já menos coletores, limpam, praticam a derrubada e a queimada da mata necessária para o plantio das colheitas sazonais, dando lugar ao semi-sedentarismo. E os primeiros assentamentos 
formam os substratos das futuras terras pretas, que se tornam comuns depois de 5.000 a.P., tão antigas quanto as terras pretas Massangana (fig. 29, coluna 6). Enquanto a terra preta da Proto-Tupí compõe um só conjunto de solo cultural-antropogênico ao longo de sua existência, com em média $50 \mathrm{~cm}$ de espessura visível à superfície, na Tupíarikém, formada pelos sedimentos da Massangana/semi-árido Jamarí, soma até $200 \mathrm{~cm}$ de espessura durante a sua existência, e só a última é visível à superfície. Essa grande diferença de espessura entre ambas tradições é resultado da diferenciação dos processos sedimentológicos entre o médio Jamari e o alto Ji-Paraná.

O clima quente aos poucos vai-se tornando menos úmido, mas ainda propiciando recursos alimentares agrícolas além do necessário, por alguns séculos, ao menos até 4.400 a. P. A fartura levou ao adensamento, que pressionou a população, que se reacomodou. $\mathrm{O}$ espaço relativo aos poucos vai ficando saturado, pressionando centrifugamente. A exemplo dos macrobandos ao meio e final do $2^{\circ}$ estágio, os menos poderosos do $3^{\circ}$ estágio aos poucos vão-se distanciando, migrando ou expandindo ca. 4.500 a.P. pela menor fartura, pela fome e pela impotência. Esta teria sido a primeira grande migração realizada por um conjunto de malocas à procura de um novo assentamento. Pelas características é provável que tenha sido para o sul, Paraguai e noroeste do Rio Grande do Sul, onde ocorrem cerâmicas com pouca decoração plástica corrugada, mais preto/vermelho sobre branco, e pintura branca sobre engobo vermelho, com predominância do tipo simples.

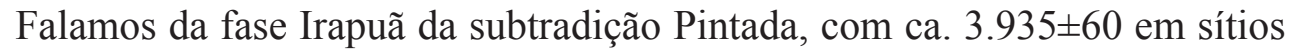
sobre altiplanos com floresta e araucária (afastados dos rios onde estavam os pré-cerâmicos da fase Caaguaçu, tradição Humaitá), que bem posteriormente chegou às margens do rio Uruguai.

A esta $1^{\text {a }}$ fase de grande expansão e migração (fig. 29, coluna $4,3^{\circ}$ estágio) $\operatorname{logo}$ se juntou a $2^{\text {a }}$ fase, agora de dispersão, não pelo adensamento populacional, mas pelo fim do Optimum Climático e início de uma semiaridez severa, ca. 4.350-4.100 a.P., de âmbito global, atingindo todo e qualquer lugar, de modo que praticamente não havia para onde ir. $\mathrm{O}$ pantanal do Guaporé não sustentou os moluscos uruá dos sambaquianos pré-ceramistas, que se dispersaram e sumiram (fig. 29, coluna 5, Estrato Guia SinimbuBacabal). No litoral nordeste do Rio Grande do Sul os abrigos registram a semi-aridez em seus estratos (fig. 25, Estrato Guia Umbu-Itapuí; fig. 29, coluna 1). Se assim foi e muitos dados indicam que sim, apenas uma minoria teria sobrevivido, como caçadores-coletores e pela necrofagia. Como em 5.000 anos de reocupações em sítios-habitação com pouco acúmulo de solos 
fica muito pouco ou nada distinguível, dificilmente esse primeiro evento de semi-aridez ficaria visível. Projetar esse evento de semi-aridez baseado em outras colunas ( 1 e 5) sobre a coluna 4 (fig. 29) foi um modo de chegar a esta possível avaliação. O segundo evento de semi-aridez menos severa, projetado sobre a coluna 4 , provém da coluna 1 entre 2.400 e 2.100 a.P., associado à coluna 6 entre 2.800 e 2.500 a.P., cuja leve diferença significa que talvez seja uma só em regiões diferentes e venha a ser corrigida (ou não) com a datação de mais amostras de carvão. Apesar do clima já não ser aquele muito quente e muito úmido do Optimum Climático, foi semelhante ao atual, permitindo a existência de matas com algum cerrado/savana. Arqueologicamente a população Proto-Tupíguaraní se recuperou e expandiuse acima do pico ca. 2.900-2.800 a.P., tendo ocasionado uma $3^{\text {a }}$ fase com novo evento de expansão e migração (fig. 29, coluna 4), para sul e sudeste mais uma vez, agravado pelo segundo evento de semi-aridez menos severa, levando à 4 a fase novamente de dispersão (fig. 29 coluna 4), ca. 2.800 e 2.600 a.P. Arqueologicamente, a população mais uma vez estava refeita na "terra natal" e continuou a crescer moderadamente ou apenas se repondo. Poderia

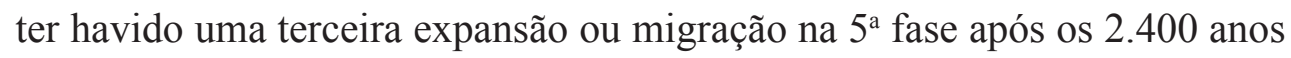
a.P., durante os 2.300 anos finais da Proto-Tupíguaraní, sem evidências de semi-aridez marcante.

\section{Do porquê da nossa arqueologia}

Encerrado o PROPA, as pesquisas prosseguiram pelo PRONAPABA - Programa Nacional de Pesquisas Arqueológicas na Bacia Amazônica. Continuamos no Sudoeste da Amazônia (Rondônia, Amazonas, Mato Grosso) de 1978 a 1983, por acaso, devido à abundância de rios com o nome de preto ou branco. No seminário do PRONAPABA em 1968, no Museu Goeldi, foi aventado o PRONAPABA enquanto olhávamos as amostras cerâmicas da Amazônia; algumas depositadas por etnólogos. Dentre elas uma nos chamou a atenção pelo "ar psicodélico do tratamento plástico e pintado multicor", com uma etiqueta onde constava "Rio Branco". De Guajará-Mirim, calafetado o barco, para lá navegamos Guaporé acima, passando o rio Branco ou Cabixi do Guaporé e encostando no rio Piolho, MT. A cerâmica de lá revelou-se em nada assemelhada à amostra do Museu Goeldi, mas com ela elaborei minha dissertação de mestrado (Miller 1983b). No Guaporé tinham estado, até então; Erland Nordenskjöld, em 1913-14, e Juergen Riester G., em 195456. Etta Becker-Donner também esteve nestes dois rios Branco: um afluente da margem direita do Guaporé, RO, e o outro afluente da margem esquerda 
do rio Negro, AM, sendo deste último a "cerâmica psicodélica" (como definitivamente ficou constatado em 1998) e não do rio Branco (ou Cabixi) do Guaporé.

Como tantos outros pesquisadores, nós de longa data pensávamos em como e onde se daria o reconhecimento da cultura material do Tupíguaraní original. Consideramos terem sido decisivas as pesquisas no noroeste de Mato Grosso, no Abrigo do Sol dentro do Refúgio Guaporé (Miller 1987a). Apesar de concentrados nelas, esse acontecimento levou-nos a encontrar, a apenas dois quilômetros do abrigo, em 1974, nosso primeiro sítio com cerâmica corrugada no sudoeste amazônico e, junto ao posto Marco Rondon, em 1975, nosso primeiro sítio com cerâmica corrugada em Rondônia, a ca. 300 km para o norte, possível limite sul do Alto-Jiparaná. Pouco a oeste desse local, pela margem esquerda do Ig. Melgacinho, a Comissão Rondon em 1913 contatou duas malocas dos Quêpiquiriuate (Rondon 2003, Rondon e Faria 1948), identificados como falantes de língua da família Tuparí (informação pessoal de A. D. Rodrigues).

Recordando: até 1974, quando foram iniciadas as pesquisas arqueológicas sérias do PROPA (Programa Paleoíndio), em Mato Grosso e Rondônia de 1974 a 1977 (Miller 1974-75, 1977), voltado, como o nome esclarece, para o homem na transição pleisto-holocênica pan-americana e seu meio, parecia um contrasenso contraposto ao que a teoria dominante declarava até então: que não seria possível a Amazônia ser colonizada por povos que não possuíssem agricultura. Tal era (e ainda é) o despreparo de alguns antropólogos estrangeiros em relação à dispensa florestal equatorial/tropical, nem tanto florestada durante o último máximo glacial até o Holoceno Arcaico, muito menos ao sul do Sudoeste da Amazônia, visto 4/5 dela estarem no hemisfério sul. Mas, retornando ao assunto, com essa aparente digressão queremos relembrar que, seja qual for o projeto arqueológico, durante as viagens o pesquisador deve fazer jus ao título e não pregar o olho, ficando atento não só à paisagem, mas ao que possa estar contido nela em termos associados à arqueologia; aí entram os indicadores bióticos de subsistência direta e indireta relacionada à cadeia alimentar e ao ciclo anual.

Aos sábados e domingos "descansávamos" das escavações no Abrigo do Sol, que foi o primeiro sítio pré-cerâmico amazônico, que já deveria ter acabado com o mito que negava e nega a Amazônia aos não-agricultores, segundo Steven Mithen (2007:381 e 597), citando obras de T. N. Headland (1987) e Robert Bailey et al. (1989). Como prova contra este mito Mithen 
cita o trabalho de Ana C. Roosevelt (1996) no abrigo da Pedra Pintada, PA.

Em 1974, percorrendo os horizontes circundantes próximos e distantes, dentre dezenas de descobertas fascinantes, tendo por companhia e guia alguns guerreiros Wasúsu, um Cesna nos transportou à Cidade Laboratório de Humboldt, em construção, a justo montante da cachoeira Dardanelos (1975); subimos o Aripuanã até bem acima da corredeira dos Patos e descemos o Dardanelos alguns quilômetros, mas nenhum traço de cerâmica corrugada ou pintada, só fragmentos cerâmicos da família Mondé (como constatamos anos após). Na segunda ocasião, nosso Jeep Willys nos levou mais Rondônia a dentro, até o posto Marco Rondon (linha telegráfica), nome dado ao nosso primeiro sítio com alguma cerâmica corrugada em Rondônia, no sul da "terra natal" dos falantes do Tronco Tupí, situado à margem esquerda do igarapé Melgacinho, afluente do rio Comemoração.

\subsection{Da arqueologia de campo}

Com os padrões da cerâmica e dos sítios Tupíguaraní da Faixa Costeira e da cerâmica corrugada próximo ao Abrigo do Sol no sítio MT-GU-27: Tamanduá e do RO-RO-3: Marco Rondon na memória e nos relatórios, prosseguimos na busca com vistas à cerâmica corrugada e pintada do Prototupí original. Planejamos cercar e ir apertando o cerco sobre a região da "terra natal" ou mesopotâmia Guaporé-Madeira e Aripuanã, como passamos a chamar essa área de interesse. Com base na hipótese de Rodrigues $(1958,1964)$, a primeira investida foi sobre a fronteira ocidental: do alto Guaporé mato-grossense, pelo Mamoré e Madeira até a confluência com o rio Aripuanã amazônico.

Começamos em 1978 pela nossa área 10 da programação. Devido às chuvas, sempre no final do segundo e princípio do primeiro semestre, ficamos no ambiente urbano/suburbano da cidade de Porto Velho, junto do rio Madeira. A cidade era muito esparsa, terrenos baldios com a laterita à mostra no solo coberto por capim sapé e, não raro, uma jibóia "arco-íris" nos sítioshabitação, cuja terra-preta, eivada de cerâmica, era utilizada para formar os canteiros ornamentais públicos e particulares. As "sobras" das peneiras: cerâmica, lâminas de machado, etc., iam barranco abaixo, ali ficando ou indo com a água. Assim, quase todas sumiram antes de chegarmos, com o progresso sepultando ou destruindo as "sobras", as oficinas líticas virando alicerces, muros e brita. Percorremos todas as ruas, estradas e trilhas até pouco acima da Cachoeira do Teotônio. Dessa pesquisa em ambas as margens resultou um 
aglomerado de sítios-habitação, que denominamos Subtradição Jatuarana da Tradição Pintada amazônica, a mais antiga com datações e estimativa até ca. 3.000 anos a.P. contínuos, com centro e "capital" em Teotônio, com ocupação mais extensa e intensa. Ela lá se assentou já pronta! Nesses 3.000 anos apenas inverteu a popularidade, da decoração mais plástica para a mais polícroma. Onde deixou suas origens? No segundo semestre, durante a estiagem, pesquisamos a área 10, desde Abunã, descendo o rio Madeira, até o interior do Lago Cuniã e subindo os baixos cursos dos afluentes, tendo encontrado mais sítios Jatuarana e algumas tradições regionais nos afluentes. Até fins de 1978, as únicas ocorrências de cerâmica corrugada no sudoeste amazônico ainda eram as duas de 1974-1977, uma perto do Abrigo do Sol, MT, e a outra no antigo Marco Rondon, no sul do Alto-Jiparaná, RO.

Em 1979 - área 10 estendida ao Aripuanã. Complementando o médio rio Madeira, pesquisamos do Lago Cuniã até o baixo curso do rio Manicoré: mais sítios Jatuarana. Subimos parte do Aripuanã, Marmelos e Maicí, onde estavam os Pirahã, acerâmicos com agricultura moderna (introduzida pelos missionários do SIL) sobre uma terra-preta. Rio Marmelos acima uma cultura cerâmica sui generis, a Jutaí, aos $90-100 \mathrm{~cm}$ deu $7.330 \pm 100$ a.P. Nada localmente colaborou para justificar esse resultado: a cerâmica estava muito bem preservada, com decoração plástica delicada e apliques zoomorfos, o sítio assentado em dique marginal arenoso inconsolidado, sem perturbação. Sem qualquer indício de pré-ceramistas, tudo com aparência de no máximo um milênio. No rio Ipixuna, no povoado homônimo, encontramos alguns remanescentes Kawahíwa ou Parintintim, que desciam até alí para trocar suas peneiras indígenas por cerâmica neobrasileira. Aí encerramos a procura por indícios da cerâmica corrugada nas proximidades do rio Madeira, sem resultados em nossa varredura desde as nascentes do rio Guaporé no Mato Grosso (Miller 1979, 1982).

Em 1980 -área 11: baixo rio Mamoré até o Abunã. Subimos o Mamoré e o Guaporé, apenas anotando as terras-pretas, aliviando o peso do combustível, até o rio Piolho no Mato Grosso (daí para cima já conhecido desde 19741977). Iniciamos a descida do Guaporé e as pesquisas em ambas as margens. Por não estarmos certos de que as culturas eram diversas entre as margens direita e esquerda, visitamos alguns sítios bolivianos. Realmente as culturas só variam a montante ou a jusante. Todas, porém, possuem uma a várias valas com taipas ao lado, em semicírculo (Miller, 1983b). Subimos os baixos cursos dos afluentes maiores da margem direita. Fomos aos postos indígenas ao longo do Guaporé, mas nada relativo à cerâmica corrugada apareceu. Dos 
Makuráp, a montante dos sambaquis, cavalgando ao longo de um dia, próximo ao rio Branco (mais um rio Branco; este leva aos antigos sítios cerâmicos Tupí-Tuparí no planalto, junto ao Apediá ou Pimenta Bueno). Encontramos de tudo, menos cerâmica corrugada, nas terras da Depressão do Guaporé (Miller, 1983b), margeando o Pantanal do Guaporé. Com o limite ocidental da "terra natal" fora de cogitação, pelo não encontro de cerâmica corrugada, tínhamos todo o espaço até o limite oriental, o espaço entre o Madeira e o médio e alto Aripuanã por investigar (Miller, 1980, 1982, 1983a).

Em 1983 pesquisaríamos a área 09, que abrangia o médio rio Aripuanã. Por dificuldades com o transporte via rio, substituímos o baixo-médio Aripuanã pelo baixo-médio rio Roosevelt, dividido entre o Amazonas e o Mato Grosso, ficando: ao norte da BR-230, ao sul o rio Roosevelt com o Madeirinha e, ao centro, a confluência do Roosevelt com o Aripuanã. Dos sítios localizados foram pesquisados 15 sítios-habitação com terra preta. Sete destes são Proto-Tupíguaraní, com dois sítios no rio Marmelos/BR-230, no parque Tenharim, próximo do posto Tenharim, com cerâmica corrugada e vestígios de pintada. O tuxaua local, sem ser induzido ou inquirido, afirmou ser de seus antepassados Tenharim. Outros quatro sítios-habitação estão no rio Roosevelt e mais um está no baixo Madeirinha (que, com o Branco e o Machadinho, originam-se na porção sudeste, a leste do Alto-Jiparaná, divisa com Mato Grosso). Os cinco sítios também são cemitérios com vasilhame cerâmico total ou parcialmente corrugado ou simples. Dois estão no Estado de Mato Grosso (MT-RV-01 e 02) e cinco no Estado do Amazonas (AMMC-55 e 56; NA-07 a 09). Das 22 urnas funerárias localizadas, 14 estavam em MT-RV-02. Só foram extraídas cinco urnas funerárias, duas em AM-NA07 e três em AM-NA-08, devido a nossa impossibilidade, na ocasião, de transportar mais (figs. 11 a 13). Neste mesmo sítio (NA-08), numa reentrância estreita e vertical $(0,5 \times 1,50 \times 2,50 \mathrm{~m})$, desde a superfície, junto ao talude vertical da barranca do rio Roosevelt, aberto pelo escoamento e erosão das águas pluviais, conseguimos avistar, ainda parcialmente apoiadas na terra envolvente, seis vasilhas inteiras, médias (Ø 45 a $60 \mathrm{~cm}$ ), empilhadas de bocas para baixo. A superior globular e totalmente corrugada (rara); as duas inferiores, simples, com bordas extrovertidas, fundo cônico e base aplanada; três com bordas amplas e extrovertidas corrugadas, bojos amplos simples com fundo cônico e base boleada numa e aplanada em duas (1983a). Parece que estamos diante de uma das dispersões mais recentes de um subgrupo Proto-Tupíguaraní do ramo Kawahíb, dentro da "terra natal", descendo o rio Roosevelt. As formas são as que, no momento, mais se assemelham às 
do litoral/sul, e com menos de 1.300 anos, ou seja, 1.210 \pm 60 anos a.P. (figs. 14 e 15). Daí para montante, no curso médio e nas nascentes, em termos de arqueologia, a bacia do Roosevelt deve conter os sítios Proto-Tupíguaraní mais assemelhados aos do litoral, em formas, datações, etc., segundo os indícios encontrados, mas também sítios de Tupímondé (pelo menos Paitér ou Suruí), com cerâmica simples, de cujo passado arqueológico pouco se sabe.

\subsection{Da pesquisa de campo sem intervenção física}

Dentre outras pesquisas de campo e laboratório, entre 1984 e 1987 (Miller 1987d, 1987e) e, de 1987 para cá, continuamos com as localizações, sem intervenções, apenas com observações visuais. Foi melhor fazer estas à noite, com foco de lanterna dirigido entre transversal a tangencialmente sobre sítios visíveis ao longo da malha rodoviária e barrancas: ruas dentro das áreas urbanas, suburbanas, e estradas rurais. Distinguindo os sítios quanto à presença ou não de cerâmica, ao tratamento de superfície e à cerâmica com ou sem corrugado, ou com corrugado/pintado. O objetivo era e é o de delimitar o espaço físico e a distribuição da Proto-Tupiguaraní em primeiro lugar, seguido das demais culturas, como Tupituparí, Tupimondé e Tupiarikém, respectivamente a ocidente, oriente e sul, e outras culturas não-Tupí. Nesse sentido, ainda que não exaustivamente, foram localizados mais de uma centena de sítios com terra preta e cerâmica corrugada, muitos com pintada, e outros tipos plásticos, a maioria na Área Alto-Jiparaná, ou seja, tendo o rio Ji-Paraná e a BR-364 como eixo noroeste-sudeste - a noroeste desde a cidade de Ouro Preto do Oeste na BR-364 e desde a cachoeira do Arregaço no rio Ji-Paraná, a jusante da cidade de Ji-Paraná, e, no extremo sudeste, até os baixos cursos dos rios Pimenta Bueno e Comemoração, inclusive (Lat. S. $\left.12^{\circ} 02^{\prime}\right)$. Incluídos também os afluentes da margem esquerda desse eixo fluvial e da margem direita, com parte das nascentes do rio Branco, afluente da margem direita do rio Roosevelt, tendo a leste a Serra da Providência, onde predominam os falantes da família Mondé. Nestas pesquisas sem intervenções temos incluído informações de vários colaboradores que atuam em órgãos ambientais de Rondônia, das quais as mais dignas de confiança provêm do Prof. Josuel A. Ravani da SEDAM, desde 1984.

\section{Do potencial arqueológico: médio Ji-Paraná}

Nos anos de 1986-87 efetuamos duas avaliações de potencial arqueológico, com a agregação de oito sítios Proto-Tupíguaraní: um 
aglomerado de sete sítios-habitação com terra preta a morena, que delimitaram o norte da Área Alto-Jiparaná da Proto-Tupíguaraní, período inicial; e um pequeno cemitério isolado, no provável limite oeste.

A primeira avaliação em 1986 foi sobre o médio Ji-Paraná, incluindo parte do baixo alto Ji-Paraná, desde pouco acima da cidade de Ji-Paraná até pouco abaixo de JP-14, para a Hidrelétrica do rio Ji-Paraná/Eletronorte, ao longo de $230 \mathrm{~km}$ de rio (Miller 1987b).

A segunda foi ao longo da BR-429, que, partindo da cidade de Presidente Médici junto à BR-364 e a seu nordeste, ruma para sudoeste, cruza o vale do rio Muqui, margem esquerda, e segue sobre a chapada dos Parecis; perpassa o divisor de águas e ingressa no vale do Guaporé, descendo ao longo do rio São Miguel, ruma paralela, mas bem afastada do Guaporé e, contornando o rio São Domingos pela margem direita, chega a Costa Marques, abaixo do Pantanal e junto do Guaporé, margem direita (Miller 1987c). Foram localizados 22 sítios, dos quais somente um contém cerâmica Proto-Tupíguaraní, sem corrugado, somente pintada, espalhada sobre $250 \mathrm{~m} 2$. A coloração dessa área é a mesma do solo sem cerâmica, não tendo característica de acampamento, nem de sítio-habitação, mas de urna funerária atingida pela lavoura de mandioca.

\subsection{Das análises de laboratório}

Tradição Proto-Tupíguaraní; conjunto Ipitaba (ex-Urupá).

Esta foia primeira análise experimental da cerâmica Proto-Tupíguaraní, sobre as coleções não-selecionadas de um conjunto com seis sítioshabitação. Não passa de uma nota-prévia, provisória e substituível. Estão situados dentro da Área Alto-Jiparaná, em sua porção norte, da cachoeira do Arrepio até o sul do espaço suburbano da cidade de Ji-Paraná, no centrosul da mesopotâmia Guaporé-Madeira e Aripuanã (Rodrigues 1958, 1964, 1986). O trabalho foi coordenado por Eurico Th. Miller com a participação da arqueóloga Rosiclér Theodoro da Silva e do aprendiz Josuel A. Ravani em 1986-87, em campo e laboratório (Miller 1987b: 36-60). Revisada, esta primeira etapa das análises se mostrou ainda válida, dentro dos propósitos de conhecê-la e compará-la com a cerâmica Tupíguaraní da Faixa Costeira. Como o termo urupá, então empregado, presta-se a confusão com os índios Urupá da família linguística Txapakúra, nós o substituímos por Ipitaba, supostamente de origem Tupí-Guaraní. 
A distância entre os sítios e o rio Ji-Paraná oscila entre 110 e $330 \mathrm{~m}$. Topologicamente, essa distâncias são maiores ou menores de acordo com a topografia local, que ora apresenta elevações baixas, ora planícies de inundação. Sempre que a relação topografia e nível máximo das cheias permite, os sítios se localizam mais próximos das águas correntes, preferentemente em local contendo o conjunto solo medianamente alto e suave, rio e afluente. Topologicamente, este modelo de sítios-acampamento desde o pleistoceno também se tem mostrado válido para sítios-habitação e tem sido aplicado, com sucesso quase absoluto, na localização de sítios dentro da floresta, em savanas, campos, etc., ocorrendo o mesmo na área de abrangência da UHE Ji-Paraná. Os sítios ocupam normalmente as porções mais suaves do topo e flanco suave das elevações, entre 11 e $21 \mathrm{~m}$ acima das águas de estiagem $(9 / 10 / 86)$. O solo é normalmente areno-argiloso ou argilo-arenoso, resultante do colúvio e elúvio de rochas ígneas intrusivas, de coloração marrom avermelhada a vermelho amarelada.

No espaço dos sítios-habitação, a área se destaca por uma coloração que varia de marrom acinzentada a preto acinzentada. Os testemunhos arqueológicos, como fragmentos cerâmicos e líticos, cobrem uma área desde $120 \times 150 \mathrm{~m}\left(14.130 \mathrm{~m}^{2}\right)$ até $280 \times 360 \mathrm{~m}\left(79.128 \mathrm{~m}^{2}\right)$, com eixo maior paralelo ao curso fluvial mais próximo.

$\mathrm{O}$ material cultural não forma concentrações nítidas, devido às reocupações; onde estas não ocorrem, o solo é pouco ou nada escuro (pela erosão ou lavagem pluvial de superfície), apresentando os testemunhos em concentrações nítidas. Em solos já desmatados e intensamente trabalhados ou limpos com trator, o material aparece disperso por toda área do sítio. $\mathrm{Na}$ floresta, ocorrem pequenos focos de cerâmica correspondendo a locais de árvores tombadas, buracos de tatu, chafurdação de porcos do mato, formigueiros e outros. Afora esses indicadores, ocorrem espécies de vegetação auxiliando na localização dos sítios-habitação, que normalmente apresentam uma camada superior não arqueológica ou estéril de 3 até 8 $\mathrm{cm}$ de espessura. A espessura da camada fértil varia de sítio para sítio e dentro de cada sítio, sendo normalmente mais espessa na porção central (com 25 a $65 \mathrm{~cm}$ ), mais uma camada estéril superior, quando na floresta. $\mathrm{Na}$ área da Proto-Tupíguaraní (alto Ji-Paraná), os sítios-habitação contêm normalmente evidências culturais, em sua grande maioria pertencentes à Proto-Tupíguaraní; contudo, não é rara a ocorrência de evidências cerâmicas de outras tradições culturais ceramistas. 


\subsection{Súmula descritiva dos sítios}

$\mathrm{RO}-\mathrm{JI}-15:$ URUPÁ

Sítio-habitação localizado na zona urbana da cidade de Ji-Paraná. Situase às margens esquerdas dos rios Ji-Paraná ao leste e Urupá ao Sul, justo na confluência. Dista destes 130 e 120 m, respectivamente. A forma é elipsóide, 210 x $160 \mathrm{~m}\left(26.376 \mathrm{~m}^{2}\right)$, com eixo maior paralelo ao rio Urupá. Assenta-se sobre uma ponta de terra firme, $16 \mathrm{~m}$ acima deste rio (estiagem 09/86). No extremo leste há ruínas de um antigo entreposto de borracha com algumas árvores frutíferas. Toda a área, ultrapassando a do sítio arqueológico, foi limpa com trator, significando que alguns centímetros do topo do sítio foram removidos e perturbados. O solo do sítio é areno-argiloso-humoso, de cor marrom claro acinzentado e a área circundante de cor marrom amarelado, argilo-arenoso-humoso. Um corte experimental de 2 × $2 \mathrm{~m}$ ao centro-norte da área revelou evidências cerâmicas e líticas até $45 \mathrm{~cm}$ de profundidade e grânulos de carvão até $65 \mathrm{~cm}$. Alguns fragmentos cerâmicos não-ProtoTupíguaraní (fase Inimbó) ocorrem a 30-33 cm deste sítio. Dista de RO JI- 16: Abril, cerca de 0,75 km para o sul deste e de RO - JI - 25: IBDF, aproximadamente $2,8 \mathrm{~km}$ para leste-sudoeste.

$\mathrm{RO}-\mathrm{JI}-16: A B R I L$

Sítio-habitação às margens esquerdas do rio Ji-Paraná e do igarapé Dois de Abril, dos quais dista respectiva e aproximadamente 150 e 200 metros, encontrando-se a cerca de $750 \mathrm{~m}$ do RO - JI - 15. Suas dimensões são as mesmas deste último, mas não é possível precisar as medidas métricas porque $\mathrm{RO}-\mathrm{JI}-16$ está sob a parte urbanizada central, ou seja, sob edifícios, casas contíguas, ruas e passeios pavimentados ou aterrados com cascalho. Os indícios de sua existência se devem às três oficinas líticas com afiadores de machado, que levaram ao estudo topográfico e localização de poucos cacos cerâmicos junto a um canteiro de obras, em solo com características de sítio-habitação. $\mathrm{O}$ sítio assenta-se sobre terreno alto, $12 \mathrm{~m}$ acima do rio na estiagem, com suave declividade para o rio e o igarapé. O solo é arenoargiloso marrom acinzentado, mas na periferia apresenta-se argilo-arenoso avermelhado. Moradores da área lembram-se da existência de cacos de cerâmica no local, mas tudo foi urbanizado alguns anos atrás, com a abertura da Av. Marechal Rondon. 
$\mathrm{RO}-\mathrm{JI}-17:$ NOVA VIDA

Sítio-habitação localizado a 110 m da margem esquerda do rio Ji-Paraná, a jusante e contíguo à corredeira São Carlos; o igarapé homônimo situa-se a 1500 $\mathrm{m}$ a montante. Dentro do município de Ji-Paraná, dista da ponte da sede $22 \mathrm{~km}$. O sítio está sobre terra firme, ocupando o topo em forma de "sela", 18-21 m acima do rio. Ocupa área elipsóide com 360 x $280 \mathrm{~m}\left(79.128 \mathrm{~m}^{2}\right)$. O solo é argiloareno-humoso, pegajoso e plástico; nas porções mais altas e na encosta voltada para o rio afloram macacões e rochedos de rochas intrusivas sem evidências de exploração humana. A floresta foi substituída por denso capinzal, o que dificultou a coleção arqueológica de superfície, considerada pobre. Foi executado um corteexperimental de 2 × 2 m, com cerâmica de $0-25 \mathrm{~cm}$ e raros grânulos de carvão até $40 \mathrm{~cm}$ de profundidade.

$\mathrm{RO}-\mathrm{JI}-23:$ IPIRANGA

Ocupação "A" do sítio-habitação, localizado na zona urbana de JiParaná, à margem direita do rio homônimo, no bairro Nova Brasília. O sítio é lindante à BR-364 pelo oeste; com forma elipsóide de 290 x 230 m (52.339 $\mathrm{m}^{2}$ ), está encaixado entre as ruas Colorado do Oeste ao sul, Carlos Luz a leste, e Taraucá ao norte. Pelo nordeste, a $130 \mathrm{~m}$ corre um pequeno igarapé de leste para oeste, arqueado para o sul. A cerâmica Proto-Tupíguaraní ocupa quase todo o espaço da área "A", enquanto a porção "B", a nordeste do sítio, é ocupada pela cultura Inimbó, de tradição a determinar. O terreno resultante da rocha vulcânica intrusiva é medianamente elevado e aplanado, de cor avermelhada, argilo-arenosa, medianamente plástica e pegajosa. Dista do rio, para leste, $1200 \mathrm{~m}$. O solo do sítio é cinza avermelhado, areno-humoso não compacto, pouco plástico e pegajoso. $\mathrm{Na}$ área " $\mathrm{A}$ " foram efetuadas coleções de superfície e o corte-experimental C-2. Não se observou, em campo e laboratório, interdigitações das cerâmicas Proto-Tupíguaraní e Inimbó. A primeira ocupa a porção mais alta da área e a fase Inimbó está mais próxima do igarapé. A área está repartida em quadras totalmente urbanizadas, mas, com boas condições de estudo estratigráfico. O corte C-2, de 2 × $2 \mathrm{~m}$, proporcionou cerâmica até a $40 \mathrm{~cm}$ e poucos grânulos de carvão até a $50 \mathrm{~cm}$ profundidade.

$\mathrm{RO}-\mathrm{JI}-26:$ BRIGADA

Sítio-habitação situado na zona urbana da cidade de Ji-Paraná, município homônimo, pelas margens esquerdas do rio do mesmo nome e do rio Urupá, 
dos quais dista 3,2 e 2,6 km, respectivamente. O igarapé Dois de Abril passa $300 \mathrm{~m}$ ao sul, em parte canalizado. O sítio é elipsóide, com 176 × $150 \mathrm{~m}$ $\left(19.546 \mathrm{~m}^{2}\right)$, com eixo maior paralelo ao igarapé. Parte do sítio está ocupada por prédios do quartel da Polícia Militar. Situa-se $950 \mathrm{~m}$ para nor-nordeste deste. A área, depois de desmatada há 10 anos, teve uso agropastoril. O sítio está sobre uma colina rasa, com suave inclinação periférica. $\mathrm{O}$ solo no sítio é argilo-arenoso de cor cinza avermelhado e o solo circundante vermelho amarelado escuro. O solo foi muito perturbado com posição dos cacos muito sub-horizontal, não recomendado corte-experimental. Efetuaram-se coletas de superfície.

\section{$\mathrm{RO}-\mathrm{JI}-28:$ ESCOLA}

Sítio-habitação na zona rural do município de Ji-Paraná, a $330 \mathrm{~m}$ da margem esquerda do ribeirão Riachuelo, afluente da margem direita do rio JiParaná. Está a 25 m da escola rural "Monte Castelo", da Linha 74, situada na Linha 128. Há 12 anos a floresta foi substituída por agricultura e pastagem. O solo do sítio é argilo-arenoso de cor vermelho acinzentado e na periferia apresenta-se mais argiloso e vermelho amarelado. O sítio é elipsóide, com 120 x $150 \mathrm{~m}\left(14.130 \mathrm{~m}^{2}\right)$. O eixo maior é paralelo ao ribeirão. Situa-se sobre uma colina baixa, com gradiente suave para o ribeirão. Além da coleta da superfície, foi executado um corte-experimental ( 2 x $1 \mathrm{~m})$, com cerâmica até $45 \mathrm{~cm}$ e carvão em pequena quantidade até $55 \mathrm{~cm}$ de profundidade. RO - JI -28: Escola está a 6,6 km a sudeste-leste de RO - JI - 17: Nova Vida.

\subsection{Do material cultural cerâmico}

As coleções de superfície, não selecionadas, e os cortes-experimentais efetuados nos sítios-habitação do conjunto Ipitaba atingem 6.399 fragmentos de vasilhame. A classificação experimental resultou em 5 tipos simples, 9 tipos decorados (denominados pelo sistema binominal) e um não classificado: Ipiranga Simples (27,17\%), Abril Simples (42,28\%), Escola Simples (7,12\%), Brigada Simples (10,84\%), Ipitaba Simples $(5,17 \%)$, Abril Vermelho (1,25\%), Ipiranga Pintado (1,81\%), Ipitaba Corrugado (1,71\%), Ipitaba Corrugado-Ungulado (0,52\%), Ipitaba Ungulado (0,56\%), Ipitaba Serrungulado $(0,10 \%)$, Ipitaba Roletado $(0,06 \%)$, Ipiranga Ponteado $(0,11 \%)$, Escola Inciso $(0,46 \%)$ e Não-classificado $(0,29 \%)$.

Os tipos decorados atingem $7 \%$. 
O Não-classificado compreende 18 fragmentos: 11 com inciso, 4 da fase Inimbó, 1 digitado e 2 simples. Entre os tipos simples predominam o Abril Simples e o Ipiranga Simples, enquanto nos decorados os mais populares são o Ipiranga Pintado, o Ipitaba Corrugado e o Abril Vermelho. Com base nos fragmentos de bordas, bojos, bases e recipientes em restauração, foram reconhecidos os grupos maiores do vasilhame, compreendendo tigelas em meia calota e meia esfera, vasos esféricos, cônicos, carenados e assador, cujos tipos e frequências estão por serem determinados em detalhe. As bases dos recipientes são plana, cônica, convexa e em pedestal.

\subsubsection{Súmula descritiva do material cultural cerâmico}

\subsubsection{Ipiranga simples: $1709(20,17 \%)$}

\section{Pasta:}

método de manufatura: acordelado

antiplástico: areia fina e fragmentos de quartzo até $0,5 \mathrm{~mm}$; grânulos de hematita e argilito, e frações menores de outras rochas e minerais, que ocasionalmente atingem $1 \mathrm{~mm}$.

textura: os antiplásticos estão regularmente distribuídos na pasta, raramente formando concentrações; alvéolos de ar são raros e diminutos, subcirculares, não atingindo $3 \mathrm{~mm}$; a fratura é irregular e pouco friável e, quando ocorre, é devido à ação do intemperismo sobre a coesão da pasta.

cor: núcleos predominantemente cinza claro e marrom acinzentado, com alguns cinza escuro e periferias marrom claro e castanho bastante uniforme; podem ocorrer núcleos cinza escuro com periferias externas branquicentas em exemplares do tipo Ipiranga Pintado.

queima: oxidação incompleta

\section{Superficie:}

cor: pela superfície externa predomina o marrom claro e raramente um castanho escuro; a face interna, em sua maioria, é levemente mais escura e acinzentada; observa-se um tom enegrecido, que na face interna pode estar acompanhado de placas de até $0,5 \mathrm{~mm}$ de espessura de restos orgânicos carbonizados, não se notando essa particularidade na face externa; devido ao intemperismo, não há certeza quanto à sua origem (se por queima ou banho), entretanto foram computados nos tipos simples. 
tratamento: o alisamento é regular na maioria da amostragem, deixando leves irregularidades em ambas as faces, como marcas longas sub-horizontais leves e perceptíveis à luz tangencial; a leve aspereza se deve mais ao intemperismo; não foram observadas trincas, nem manchas de queima.

Dureza: varia de 2,0 a 3,5 predominando 2,5 a 3,0.

Forma: tigelas de formas em meia calota e hemisférica, e vasos globulares, carenado-cônicos e hemisférico-cônicos, por detalhar.

base: convexa, plano-cônica e cônica.

espessura da parede do corpo: varia de 3,5 a $17,5 \mathrm{~mm}$, predominando de 7,5 a $8,5 \mathrm{~mm}$.

\subsubsection{Abril simples: 2659 (42,28\%)}

\section{Pasta:}

método de manufatura: acordelado.

antiplástico: areia fina até $0,5 \mathrm{~mm}$; fragmentos de quartzo, grânulos de hematita e frações menores de outras rochas e minerais em menores quantidades, atingindo até $1,5 \mathrm{~mm}$, ocasionalmente $3 \mathrm{~mm}$.

textura: os antiplásticos estão regularmente distribuídos na pasta; alvéolos de ar são menos raros que em Ipiranga Simples, diminutos, não atingindo $3 \mathrm{~mm}$; a fratura é irregular e pouco friável, principalmente devido ao intemperismo sobre coesão da pasta.

núcleos predominantemente cinza claro e marrom acinzentado, com alguns cinza escuro, com periferias marrom claro e castanho bastante uniforme.

queima: oxidação incompleta.

\section{Superficie:}

cor: predomina o marrom claro seguido pelo castanho e raramente marrom escuro na superfície externa; internamente, as cores são de tonalidade mais escura e raramente idênticas ou enegrecidas (ver observação em Ipiranga Simples).

tratamento: o alisamento é geral e mal alisado em ambas as superfícies, sendo perceptível por luz tangencial e pelo toque; ocorrem algumas manchas de queima; a aspereza se deve mais ao intemperismo; é frequente o afloramento do antiplástico.

Dureza: varia de 2,0 a 4,0, predominando de 2,5 a 3,0. 
Forma: tigelas de formas em meia-calota-hemisférica e vasos globulares, carenado-cônicos, todos por detalhar.

base: mais frequente a convexa e plano-cônica, ocorrendo também a cônica, todas por detalhar.

espessura da parede do corpo: varia de 4,5 a $19,5 \mathrm{~mm}$, predominando de 7,0 a $8,0 \mathrm{~mm}$.

\subsubsection{Escola simples: $448(7,12 \%)$}

Pasta:

método de manufatura: acordelado,

antiplástico: como em Ipiranga Simples, mais a adição pequena a acentuada de películas de mica branquicenta até $0,5 \mathrm{~mm}$.

textura: os componentes do antiplástico estão regularmente distribuídos na pasta, ocasionalmente agrupados; os alvéolos de ar são raros, não ultrapassando 2,5 mm de comprimento; a fratura é irregular e pouco friável e, quando ocorre, é mais devido à ação do intemperismo.

cor: núcleos predominantemente cinza claro a marrom acinzentado; pouco cinza escuro com periferias marrom claro e castanho e ocasionalmente esbranquiçado externamente; em geral, a cor é bastante uniforme.

queima: oxidação incompleta.

\section{Superficie:}

cor: predomina a cor marrom médio, seguida pelo marrom claro e castanho escuro, com reflexo de mica branquicenta; a superfície interna normalmente é mais escura e acinzentada; interna e externamente, pode ocorrer o enegrecido (ver observação em Ipiranga Simples).

tratamento: o alisamento é regular, com algumas irregularidades em ambas as superfícies, as quais apresentam marcas e estrias finas e longas oblíquas, perceptíveis à luz tangente; uma leve aspereza é devida ao intemperismo; raras manchas de queima.

Dureza: varia de 2,5 a 4,0, predominando de 3,5 a 3,0.

Forma: tigelas em meia-calota e hemisférica e vasos globulares, carenadocônicos, hemisférico-cônicos; todas por detalhar.

base: mais frequente a convexa e plano-cônica, ocorrendo também a cônica; todas por detalhar. 
espessura da parede do corpo: varia de 4,0 a $15,5 \mathrm{~mm}$, predominando de 6,5 a $8,0 \mathrm{~mm}$.

\subsubsection{Brigada simples: $682(10,84 \%)$}

Pasta:

método de manufatura: acordelado.

antiplástico: areia fina até $0,5 \mathrm{~mm}$; fragmentos de quartzo e grânulos de hematita e frações menores de outras rochas e minerais em menores quantidades, até $1,5 \mathrm{~mm}$, ocasionalmente até $2,5 \mathrm{~mm}$.

textura: os antiplásticos estão regularmente distribuídos com ocasionais aglomerados de mica na pasta; alvéolos de ar em regular quantidade como no tipo Abril Simples, diminutos, não ultrapassando $3 \mathrm{~mm}$; a fratura é irregular e pouco friável, mais devido ao intemperismo sobre a coesão da pasta.

cor: predomina o marrom claro avermelhado seguido pelo castanho e casos de cinza escuro e marrom escuro na superfície externa com reflexos de mica; internamente, as cores são de tonalidades mais escuras, seguidas de cores idênticas ou enegrecidas (ver observação tipo Ipiranga Simples).

queima: oxidação incompleta.

\section{Superficie:}

cor: predomina o marrom claro avermelhado seguido pelo castanho e casos de cinza escuro e marrom escuro na superfície externa com reflexos de mica; internamente, as cores são de tonalidades mais escuras, seguidas de cores idênticas ou enegrecidas (ver observação tipo Ipiranga Simples).

tratamento: o alisamento em geral deixou irregularidades em ambas as superfícies e bem perceptíveis; a aspereza ocorre, mas menos pronunciada do que no tipo Escola Simples; raras manchas de queima na superfície externa. Dureza: varia de 2,5 a 3,5, predominando 3,0.

Forma: tigelas de forma em meia-calota e hemisférica e vasos globulares, carenado-cônico, hemisférico-cônico. Todos por detalhar.

base: mais frequente a convexa e plano-cônica, todas por detalhar.

espessura da parede do corpo: varia de 5,5 a 16,0 mm, predominando de 7,0 a 8,0.

\subsubsection{Ipitaba simples: 339 (5,71\%)}

Pasta:

método de manufatura: acordelado 
antiplástico: cariapé moído até $3 \mathrm{~mm}$ de comprimento, predominando até 1 $\mathrm{mm}$, em regular quantidade, em mistura com areia fina, algum quartzo muito fino e raros grânulos de hematita, inferiores a $1 \mathrm{~mm}$.

textura: o antiplástico em alguns casos está muito bem distribuído, predominando o regularmente distribuído; pode haver casos de concentração de cariapé; alvéolos alongados de ate $3 \mathrm{~mm}$, predominando $1 \mathrm{~mm}$, com bastante porosidade; a fratura é irregular, regularmente com periferias cinza claro a cinza amarelo palha.

queima: oxidação incompleta.

\section{Superficie}

cor: predomina o cinza claro, seguido pelo cinza amarelo palha e avermelhado pela superfície externa; internamente, ocorrem as cores cinza escura e cinza clara e casos de enegrecimento (ver observação no tipo Ipiranga Simples).

tratamento: alisamento imperfeito, em alguns casos bem irregular, percebendo-se a sobreposição dos roletes pela irregularidade vertical intermitente na espessura; uma leve aspereza se deve ao afloramento do cariapé e intemperismo.

Dureza: varia de 1,5 a 2,5, predominando 2,0.

Forma: tigelas de formas em meia-calota e hemisférica e vasos globulares, carenado-cônico e hemisférico-cônico, por detalhar.

base: convexa, cônica, plano-cônica.

espessura de parede de corpo: varia de 3,5 a $30,5 \mathrm{~mm}$, predominando de 6,5 a $8,0 \mathrm{~mm}$.

\subsubsection{Abril vermelho: $79(1,25 \%)$}

Quantificação prejudicada para menos pelo intemperismo nas superfícies.

Pasta e Superficie: 18 como em Ipiranga Simples, 31 como no Abril Simples, 6 tipos Escola Simples, 13 como no Brigada Simples e 11 como em Ipitaba Simples.

\section{Decoração:}

técnica: camada de tinta vermelha normalmente esmaecida e muito delgada, aplicada diretamente sobre a face externa dos recipientes, previamente alisada.

motivo: aparentemente o engobo recobre toda a superfície dos recipientes; diagnóstico prejudicado pelo intemperismo. 
Forma: tigelas e vasos por determinar.

base: convexa.

espessura da parede do corpo: varia de 3 a $15 \mathrm{~mm}$, predominando de 6,5 a 7,5 $\mathrm{mm}$.

\subsubsection{Ipiranga pintado: 114 (1,81\%) (Figs. 04 a 06).}

Quantificação prejudicada para menos devido ao intemperismo nas superfícies.

Pasta e Superficie: 12 como em Ipiranga Simples, 39 como Abril Simples, 28 como Escola Simples, 33 como no Brigada Simples e 2 como em Ipitaba Simples.

\section{Decoração:}

técnica: a pintura é aplicada diretamente sobre a superfície externa ou interna e, raramente, em ambas previamente alisadas; nas tigelas predomina internamente, nos vasos externamente; normalmente é unicolor, em branco ou preto; a pintura branca é bem mais espessa, resultando em espessura finíssima (menos de 0,01 mm); o intemperismo e a ausência de engobo dificultam a percepção da pintura; além de muito apagada, resulta pouco contraste entre branco ou preto sobre superfície marrom e marrom claro; raros casos pintados de vermelho sobre engobo branco e pintados de branco sobre engobo vermelho.

motivo: linhas retas, raramente curvas, de 1 a $3 \mathrm{~mm}$, ocasionalmente até $6 \mathrm{~mm}$ de largura, regulares, paralelas, horizontais verticais oblíquas; pontos de 1 a 3 $\mathrm{mm}$, agrupados não muito regularmente; áreas losangulares, quadrangulares ou retangulares cheias são as formas que, puras ou associadas, resultam em composições como reticulado losangular ou quadrangular; faixas em zig-zag, faixas de triângulos concêntricos monocrômicos e zonados heterogêneos, uni- ou bicolores.

Forma: de vasos e tigelas, por determinar.

base: convexa (mais frequente) e cônica.

espessura da parede do corpo: entre 5,0 e 9,5 mm, predominando de 5,0 a $7,0 \mathrm{~mm}$.

5.3.1.8 Ipitaba corrugado: 108 (1,71\%) (Figs. 07, 08, 11, 14, 15)

Pasta e superfície: 33 como em Ipiranga Simples, 59 como no Abril Simples, 6 como Escola Simples e 10 como Brigada Simples. 


\section{Decoração:}

técnica: depressões e cristas resultantes de compressão rítmica e sistemática dos dedos, para junção dos roletes, com a pasta ainda plástica. Ocorrem ocasionalmente pequenas porções dos roletes não completamente obliterados.

motivo: as corrugações se estendem pela circunferência da superfície externa, normalmente do bojo ou ombro à borda. Não foi observada corrugação abaixo do bojo.

Forma: vasos e tigelas, por determinar.

bases: por determinar.

espessura da parede do corpo: oscila de 6,5 a $13,5 \mathrm{~mm}$, predominando $8,0-$ $9,5 \mathrm{~mm}$.

5.3.1.9 Ipitaba corrugado-ungulado: 33 (0,52\%) (fig. 08)

Pasta e superficie: 7 como em Ipiranga Simples, 17 como no Abril Simples, 4 como Escola Simples e 5 como Brigada Simples.

Decoração:

técnica: depressões, cristas e incisões associadas, resultantes da compressão rítmica e sistemática da extremidade dos dedos para a junção dos roletes, com a pasta ainda plástica; as incisões são causadas pela extremidade da borda ativa da unha.

motivo: o corrugado-ungulado se entende pela circunferência da superfície externa, normalmente do bojo ou ombro à borda; pode ocorrer somente na borda do pescoço; não foi constatada esta decoração abaixo do bojo.

Forma: vasos e tigelas, por determinar.

base: por determinar.

espessura da parede do corpo: oscila de 5,5 a 13,0 mm, predominando 7,0 a $9,5 \mathrm{~mm}$.

\subsubsection{Ipitaba ungulado: 33 (0,56\%) (fig. 09)}

Pasta e Superficie: 11 como em Ipiranga Simples, 16 como no Abril Simples, 1 como Escola Simples e 7 como em Brigada Simples.

Decoração:

técnica: incisão resultante da borda ativa da unha pressionada na superfície 
externa ainda plástica do vasilhame, previamente alisada; a maioria está regularmente disposta, vertical e paralelamente, com poucos irregulares.

motivo: as ungulações podem estar dispostas do bojo à borda, em linhas horizontais, por toda a circunferência, ou, em menor frequência, somente sobre o lábio, radialmente dispostas.

Forma: vasos e tigelas, por determinar.

base: $\mathrm{B}$ e $\mathrm{C}$

espessura da parede do corpo: entre 5,5 e 14,0 mm, predominando de 8,0 a $9,0 \mathrm{~mm}$.

\subsubsection{Ipitaba serrungulado: 6 (10,0\%) (fig. 09)}

Pasta e Superficie: todos como no tipo Ipitaba Simples

\section{Decoração:}

técnica: a compressão simultânea das pontas das unhas e dedos, em sentido oposto, na superfície cerâmica, ainda plástica, produz a formação de cordões em crista, separados pelos sulcos resultantes.

motivo: os cordões serrungulados podem estar dispostos verticalmente do bojo carenado à borda de tigelas e vasos, ou somente sobre a borda, dispostos radialmente, por toda a circunferência.

Forma: tigela rasa e vaso carenado.

base: cônica e convexa, fundo convexo.

espessura da parede do corpo: entre 9,0 e 16,0 mm, predominando 13,0 $\mathrm{mm}$.

5.3.1.12 Ipitaba roletado: $4(0,06 \%)$ (fig. 10$)$

Pasta e Superficie: 2 como em Abril Simples, 1 como no Escola Simples e 1 como em Brigada Simples.

\section{Decoração:}

técnica: a compressão dos dedos para a junção dos roletes, com a pasta ainda plástica, oblitera os roletes apenas pela superfície interna, sendo que externamente permanece a configuração.

motivo: apresenta a configuração de roletes sobrepostos e sem alisamento, como um rolo de mangueira lisa. 
Forma: vasos e tigelas, por determinar.

base: por determinar.

espessura da parede do corpo: entre 7,0 e 9,5 mm.

\subsubsection{Ipiranga ponteado: 7 (0,11\%) (fig. 10)}

Pasta e Superficie: 3 como em Abril Simples, 3 como no Escola Simples e 1 como Brigada Simples.

Decoração:

técnica: ponteado executado sobre superfície externa ainda plástica, com instrumento de seção circular a quadrangular; extremidade dirigida perpendicularmente, com depressões circulares de 1 a $2 \mathrm{~mm}$ de diâmetro algo irregulares, e oblíquo-horizontal da esquerda para a direita, com pontos oblíquos alongados e quadrangulares com área de 2-2,5 x 5-7 mm e profundidade de 0,5 a $2,5 \mathrm{~mm}$.

motivo: cobre a superfície externa perifericamente na borda a lábio ou do ombro à borda, com linhas de pontos horizontais espaçadas de 1,5 a $3 \mathrm{~mm}$.

Forma: vasos e tigelas, por determinar.

base: por determinar.

espessura da parede do corpo: entre 7,5 e 16,5 mm.

5.3.1.14 Escola inciso: 29 (0,46\%).

Pasta e Superficie: 7 em Ipiranga Simples, 9 como no Abril Simples, 2 como em Escola Simples, 9 como no Brigada Simples e 2 como Ipitaba Simples.

Decoração:

técnica: sulcos contínuos executados com instrumento apontado ou rombudo na superfície externa ainda plástica; não são profundos, atingindo $0,5 \mathrm{~mm}$ e com largura de 0,5 a $1,5 \mathrm{~mm}$.

motivo: as incisões sobre a superfície externa se estendem perifericamente da borda do ombro, em linhas paralelas retilíneas oblíquas, para a direita e esquerda, e horizontais, formando triângulos concêntricos ou zonas de linhas paralelas alternadamente para a direita e esquerda.

Forma: vasos e tigelas, por determinar.

base: por determinar:

espessura da parede do corpo: entre 4,0 e 16,5 mm, predominando 7,0 a 8,0 mm. 


\subsubsection{Não-classificado: 18 (0,29\%)}

Pasta e Superfície: 1 como Ipiranga Simples, 4 como em Ininbó Simples (cultura Inimbó), 2 como na Escola Simples e 11 com tempero de areia fina e cariapé, bem distribuídos e compactos, com superfície bem alisada.

\section{Decoração:}

técnica: 4 cacos com marcas de corda, como em Inimbó Marcado-Com-Corda, fase Inimbó; 11 cacos com incisões finas e regulares em superfície ainda plástica e bem alisada, estranho à Proto-Tupíguaraní; 1 fragmento com carena digitada; e 2 fragmentos de tigelas de bordas modeladas e complexas.

motivo: o marcado-com-corda decora o lábio da borda; o inciso cobre a borda ao fundo e pedestal de um pequeno vaso, com linhas duplas em zigzag que abrangem a periferia e se alternam com linhas duplas horizontais até meia altura, onze zonas de linhas em zig-zag paralelas horizontais e verticais preenchem a superfície, até a base do pedestal; o digitado cobre a carena de um vaso; e o modelado pela borda de tigelas forma periferias não circulares.

Forma: tigela e vaso de forma por determinar.

base: em pedestal e outras, por determinar.

espessura da parede do corpo: entre 7,0 e 14,0 mm, predominando 8,0 e 9,0 $\mathrm{mm}$.

Dureza: entre 2 e 3,5.

\subsection{Datações pelo carbono-14 $\left({ }^{14} \mathrm{c}\right)$ : tradição Proto-Tupíguaraní, Mesopotâmia Guaporé-madeira e Aripuanã - "terra natal"}

Sítio RO-JI-15: Urupá, C-1, 30-40b cm, 5.070 60 a.P., Proto-Tupíguaraní Sítio RO-JI-15: Urupá, C-1, 30-40a cm, 4.230 100 a.P., Proto-Tupíguaraní

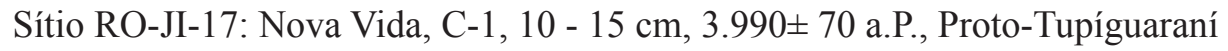
Sítio RO-JI-23A: Ipiranga, C-2, $30-40 \mathrm{~cm}, 3.760 \pm 70$ a.P., Proto-Tupíguaraní Sítio RO-JI-23B: Ipiranga, C-1, 130-150 cm, $2.340 \pm 70$ a.P., Proto-Tupíguaraní, forno

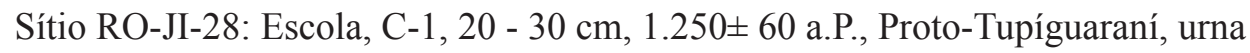
Sítio AM-NA-08: Terra Preta, C-1, $00-70 \mathrm{~cm}, 1.210 \pm 60$ a.P., Proto-Tupíguaraní, urna Sítio RO-JI-23B: Ipiranga, C-1, 60 - $68 \mathrm{~cm}, 880 \pm 60$ a.P., Proto-Tupíguaraní, forno

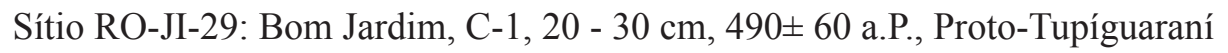

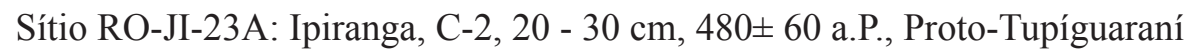


Estas são as primeiras nove datações ${ }^{14} \mathrm{C}$ de sítios-habitação com cerâmica corrugada e pintada Proto-Tupíguaraní da "terra natal", recebidas em princípios de 2001. A data mais antiga da Faixa Costeira, por sua exagerada antiguidade em relação às demais datas, para a época de 1969, pareceu précerâmica local, talvez da fase Caaguaçu, tradição Humaitá. Se agora ocorrerem mais datas entre 5.000 e 4.000 a.P. para a Proto-Tupíguaraní, a tendência será de reconsiderá-la, desta vez como registro da mais antiga expansão ou migração da Proto-Tupíguaraní, tornando-se os primeiros Tupíguaraní no interior da Faixa Costeira. Acima, encabeçando a lista, a data mais antiga Proto-Tupíguaraní da Área Alto-Jiparaná, que está ombro a ombro com a data sugerida para os falantes do Proto-Tupí (Rodrigues, 1958a): pouco mais de 5.000 anos, ou seja, 5.070 60 a.P. Não é tão grande a distância cronológica até as datações Tupíguaraní da Faixa Costeira. Como não houve uma explicação convincente contra, nós as liberamos da quarentena neste ano de 2007.

Pensamos que a Prototupí, num primeiro momento, nas $1^{\mathrm{a}}$ e $2^{\mathrm{a}}$ fases, migrou e se expandiu para o sul (fig. 29, coluna 4), depois para o leste e sudeste, fora da terra natal. Assim, montamos um cenário com alguns dados sobre uma dessas fases do oeste do rio Uruguai, sobrepondo-a cronologicamente à amostra do conjunto Ipitaba. Na mesma sequência é apresentada a tendência percentual dos principais tipos cerâmicos de cada segmento cultural; ou singularidades e particularidades: dentre os componentes do tronco Tupí: Proto-Tupí e TupíGuaraní, só o primeiro na "terra natal" pintou cerâmica sobre superfície simples; ou, nas duas a decoração externa cobre do ombro à borda, e na Irapuã antiga o tratamento plástico restringia-se ao pescoço ou borda.

Fora da "terra natal", só o resultado da fase Irapuã (Miller 1969a, 1971) com 3.935 \pm 60 , afora o Pintado sobre Simples ausente na Faixa Costeira, se parece com os resultados da "Área Alto-Jiparaná". Se alguém retomar as pesquisas de campo da Fase Irapuã, principalmente no Sítio RS-VZ-45: Parizinho-3, com maior amplitude e detalhamento, como esperamos que venha a acontecer, certamente surgirão mais datas próximas de 4.000 a.P. nas terras altas dos esporões serranos, dos rios Turvo e Guarita, e com menos de ca. 1.500 a.P. junto ao rio Uruguai.

\subsection{Datações por carbono-14 $\left({ }^{14} \mathrm{c}\right)$ : Tradição Tupíguaraní, Subtradição Pintada, Fase Irapuã/rs - Faixa Costeira}

Meio ambiente: a porção mais recente da fase Irapuã se assentou nas margens do médio e alto rio Uruguai, encobertas pela floresta caducifólia com maior incidência ao longo das corredeiras e baixios. 
Sítio RS-VZ-41: Jaboticaba C-1, 40 - 50 cm, 225 55 a.P., Tupíguaraní Sítio RS-VZ-52: B.do Turvo C-1, $30-35$ cm, 675 50 a.P., Tupíguaraní Sítio RS-VZ-44: Parizinho-2 C-1, 10 - 20 cm, $160 \pm 70$ a.P., Tupíguaraní.

Meio ambiente: longe do Uruguai, nas matas com araucária, nos patamares das encostas do planalto próximos a vertentes. Com assentamentos mais antigos.

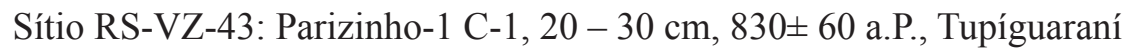

Sítio RS-VZ-45: Parizinho-3 C-1, $30-40$ cm, 3.935 60 a.P., Tupíguaraní

\subsection{Sequência da tendência percentual dos principais tipos cerâmicos}

Fase IRAPUÃ - Subtradição Pintada, Tradição Tupíguaraní.

Recente nas terras baixas do rio Uruguai.

RS - TIPOS: Simples . Pint.S . Pint.E.B..Pint.E.V.. Eng.V..Corrug. . Pinç.. Out.

$\begin{array}{llllccccc}\text { RS-VZ-41: } & 32 & .-. & 67 & .-. & .- & 1 & .-. & .-. \\ \text { RS-VZ-52: } & 37 & .-. & 58 & .- & .- & 2 & 2 & 1 \\ \text { RS-VZ-44: } & 42 & .-. & 51 & 1 & 1 & 1 & 2 & 2\end{array}$

Mais antigo: terras altas longe do rio Uruguai.

$\begin{array}{lllllclll}\text { RS-VZ-43: } & 49 & .-. & 41 & 5 & 4 & .-. & .-. & 2 \\ \text { RS-VZ-45: } & 65 & .-. & 12 & 9 & 10 & .-. & .-. & 4\end{array}$

Conjunto IPITABA - Tradição Proto-Tupíguaraní.

RO - TIPOS: Simples . Pint.S . Pint.E.B. .Pint.E.V.. Eng.V..Corrug. .Pinç.. Out.

$\begin{array}{llllllll}\text { RO-IJ-15: } \quad 92,5 & 1,56 & 0,13 & 0,11 & 1,3 & 2,3 & 0,1 & 3,5\end{array}$

Os tipos decorados atingem 7\% (5\% plástico; $2 \%$ pintado e engobado). O não-classificado compreende 18 fragmentos: 11 com inciso, 4 da fase Inimbó de tradição indefinida, 1 digitado e 2 simples.

De 2001 para cá efetuamos o levantamento de eventos climáticos constatados para os últimos 7.000 anos, no Rio Grande do Sul, Mato Grosso e Rondônia (Miller 1969c, 1987a, Miller et al. 1992, figs. 25 a 29). O levantamento resultou, num primeiro momento, num evento de muito calor e muita umidade, conhecido por Optimum Climático ao longo de ca. 2.700 anos, com início ca. 7.000 a.P. (fig. 29, coluna 5, $1^{\text {a }}$ fase), cobrindo os primeiros 700 anos dos falantes do tronco linguístico Tupí ou do Prototupí arqueológico (fig. 29, coluna 4). E num segundo momento: numa sequência de eventos ao longo de mais ca. 4.300 anos, com dois grandes eventos climáticos de semi- 
aridez (fig. 29, coluna 4, $2^{\mathrm{a}}$ e $4^{\mathrm{a}}$ fases), inter-digitados por dois outros grandes eventos de clima relativamente quente e úmido (fig. 29 , coluna $4,3^{\text {a }}$ e $5^{\text {a }}$ fases) o suficiente para o crescimento de florestas e agricultura, repetindo, ao longo de mais ca. 4.300 anos.

Esses eventos climáticos ocasionaram: as Fases 1 e 3 de farta subsistência e provável excesso de população, que levaram a pelo menos duas, talvez a três migrações e expansões, e as Fases 2 e 4 de forte semiaridez, que causaram dois eventos de dramáticas dispersões. As duas ou três expansões com migrações talvez expliquem a presença do Tupínambá no sudeste-norte da Faixa Costeira, e do Tupíguaraní da Faixa Costeira Sul e Sudeste e do Paraguai. Como aqueles eventos de semi-aridez tinham proporções continentais, essas "buscas pela terra sem mal" se repetiram ao menos por duas ocasiões, com novas levas migrantes pressionando as levas anteriores. Teriam que adentrar sempre mais microrregiões já povoadas pelos Tupí-Guaraní de levas anteriores, que por sua vez reiniciariam as dispersões sobre outras microrregiões ocupadas por outras culturas. Essas mudanças todas deveriam consumir de centenas a mais de um milhar de anos e, como a subtradição Pintada, nem todas chegariam à beira-mar (p. ex. fases Irapuã e Comandaí). Algumas levas de centenas de indígenas, entretanto, chegaram ao litoral: as das fases climáticas 1, 3 e 5; 1 e 3, ou 3 e 5; ou 1, ou 3, e talvez não tenha havido uma $5^{\text {a }}$ fase. Das fases 1 e 3 deve ter resultado a subtradição Pintada, que é a mais antiga; da fase 1, se a datação for correta, deve ter surgido a fase Irapuã (Rio Grande do Sul). É duvidoso o efeito das Fases 2 e 4 de semi-aridez severa de extensão continental sobre as dispersões. A partir daí passamos a aceitar os cerca de $5070 \pm 60$ anos a.P. para a cerâmica ProtoTupíguaraní, que na Faixa Costeira passou a ser conhecida como Tupíguraní a partir de 1969 (Brochado et al. 1969; Chmyz 1969, 1976).

\section{Da etno-história}

Nosso objetivo vinha sendo reconhecer arqueologicamente a "terra natal” da cerâmica corrugada e pintada das famílias linguísticas do Tronco Tupí de Rodrigues (1958; 1964; 1986). Partimos do pressuposto de que sua cultura material e linguagem, tal como na Faixa Costeira, são correlacionadas. Segundo os resultados de nossas pesquisas arqueológicas desde 1964, o espaço físico arqueológico é o mesmo que o espaço físico linguístico. Estão contidos entre os afluentes que, com o rio Madeira, formam a mesopotâmia Guaporé-Madeira e Aripuanã, com o rio Roosevelt de entremeio. Vejamos 
então o que a etno-história pode nos revelar sobre os rios da "terra natal" e sobre os autóctones e os alóctones.

Nosso interesse arqueológico e geográfico é o Sudoeste Amazônico e, deste, aquele espaço físico do tamanho que poderia conter a "terra natal" do tronco linguístico Tupí segundo a hipótese de Rodrigues, ou seja, o espaço físico da mesopotâmia inscrita entre os rios Guaporé-Madeira, Roosevelt e Aripuanã. Elegemos a hipótese de Rodrigues como a hipótese definitiva porque ela se enquadrou perfeitamente no espaço arqueológico desenhado pelos sítios que denominamos tradição Prototupí da "Área Alto-Jiparaná", diferenciado, porém mantendo vínculo com a tradição Tupíguaraní da Faixa Costeira. Vejamos então o que a etno-história nos pode revelar sobre essa mesopotâmia, os autóctones e alóctones que a frequentaram.

No Rio Madeira: estavam os índios da nação Ururis; os jesuítas entraram em 1683 e 1688 nos seus baixo e médio cursos e depois ficaram ausentes por trinta anos (Menéndez 1992:281-296). Trinta anos depois, em 1722 o militar Francisco M. Palheta subiu até os rios Mamoré-Guaporé (Abreu 1963:339-54).

No rio Aripuanã: lá estavam os índios Aripuanã e outros - os jesuítas entraram em 1688, no seu baixo curso (Menéndez 1992: 281296). Comerciantes das drogas do sertão, depois seringueiros começaram a paulatina subida do rio, na medida em que debilitavam e controlavam ou eliminavam os indígenas.

No Rio Marmelos: comerciantes das drogas do sertão, depois seringueiros começaram a paulatina conquista e subida do rio, na medida em que debilitavam e controlavam ou eliminavam os indígenas.

Nos rios Ji-Paraná, Jamarí e outros, de jusante a montante: comerciantes das drogas do sertão, depois seringueiros começaram a paulatina subida dos rios, na medida em que debilitavam e controlavam ou eliminavam os indígenas; os Arikém estavam no Jamari e os Karitiána em seu afluente Candeias.

Do Jaci-Paraná ao rio da Dúvida, Aripuanã, Castanho ou Roosevelt: em 1909-1915 a Missão Rondon retifica as cartas fluviais elaboradas anteriormente em rios de Rondônia/Mato Grosso e Amazonas, contactando os habitantes indígenas, mesmo os hostis (Rondon 2003).

Do rio Guaporé a Belém do Pará: Felix de Lima desce os rios Guaporé, Mamoré, Madeira eAmazonas até Belém, em 1742, anotando suas observações sobre os indígenas (Southey 1862). Missionários espanhóis em 1743 instalam 
missões à margem direita, nos cursos alto e baixo (Fonseca 1880:61). Em 1752, Rolim de Moura determina que o comércio português seja feito via rio Guaporé-Belém do Pará (Fonseca 1880:62-3). Em 1755-58, instalam-se mais missões jesuitas no rio Mequéns com índios Mekém e Guajarutá e, em 1756, com mais de mil da nação Guaririaz (Leite 1945:220). Em 1770 é levantada a primeira carta topográfica da Capitania de Mato Grosso (Fonseca 1880:73). Um quilombo de negros e índios no rio Piolho perdurou de 1771 a 1795 , tendo sido reativado em 1797, como arraial Carlota, pela notícia da existência de ouro, que não se confirmou, tendo ele sido abandonado e os ocupantes dispersados pelo Guaporé (Almeida Serra 1866:156-96, Fonseca 1880). Em 1781/82, a comissão de demarcação de limites efetuou o levantamento hidrográfico dos rios Madeira, Guaporé e Mamoré entre Brasil e Alto Peru (futura Bolívia) (Almeida Serra et alii 1857, 1866:390-96). No final do século XIX, no rio Mequéns foi criada a vila Pernambuco, onde 400 habitantes, "los cambas" - índios, caboclos e negros escravos - extraiam látex e poaia, levados para a Bolívia, Corumbá e pelo Mamoré/Madeira abaixo (Cabral 1963:163). Costa Marques encontrou cerca de 100 Guarasugwé do lado brasileiro e Nordenskjöld contatou-os em 1914.

A Carta Etnográfica de Rondônia é trabalho conjunto do antropólogo Roquette Pinto e da Comissão Rondon, e elaborado por R. Lopies em 1934. Nele, a distinção dada anteriormente aos subgrupos Tupí-Guaraní, Tuparí e outros do croqui de 1913 não é considerada, sendo substituída pelo de 'Família Tupí-Guaraní', simplesmente (Roquette-Pinto 1950: carta); o que não agrega a desejada informação. J. B. Faria (1944) reproduz os mapas etno-históricos de 1913 de Rondônia, que são inseridos no "Glossário geral das tribos silvícolas de Mato-Grosso e outras da Amazônia e do norte do Brasil" (Rondon e Faria 1948).

Curt Nimuendajú, com informes próprios, da Missão Rondon e muitos outros, que não se restringem à região em questão, sintetizou-os em seus mapas etno-históricos para a Smithsonian Institution em 1942, para o Museu Goeldi em 1943, e para o Museu Nacional em 1944, tendo utilizado 580 autores-fontes e perto de 40 dele próprio e tendo ido além das fronteiras do Brasil; os dois últimos mapas foram adequados e publicados pelas fundações IBGE e Pró-Memória (Nimuendajú 1981).

Nosso objetivo, a "terra natal" do Proto Tupí, de suas dez famílias linguísticas, das seis famílias que permaneceram em Rondônia (Rodrigues 1964, 1986), com parcialidades ainda em 1913 (Rondon 1948, 2003 [1916]), 
comprovadas pela pesquisa arqueológica de campo (Miller 1983a, 1983b, 1987b, 1987c, 1987d, 1987e, 1992b), é apresentado neste trabalho.

Essas fontes informam que em 1913 (Rondon 2003:204, 209-214; Rondon e Faria 1948; figs. 24 e 32) e 1938 (Lévi-Strauss 1996:300-341), o Kawahíb arqueológico e o Kawahíb linguístico estava assentado ao longo das margens direita e esquerda do alto rio Ji-Paraná e afluentes, e o Kepkiriwát ao longo da sub-bacia do médio e alto Pimenta Bueno. O Kawahíb, que é Tupí-Guaraní, era conhecido, então, genericamente por Pauatê, subdividido em: Majubim, Tacuatêpe, Ipoteuáte e os Parnauáte. Os primeiros estavam ao norte, desde entre as atuais cidades de Jí-Paraná e Presidente Médici, e os últimos ao sul, no baixo curso do rio Comemoração.

Em 4/5/1909 a Missão Rondon partiu de Tapirapuã, MT, porto do Sepotuba, afluente da margem direita do Paraguai, com destino ao Juruena, MT, de onde saiu em 2/6/1909. Em 29/7/1909 a Missão Rondon acampou junto à nascente de uma cabeceira a que Rondon chamou de Comemoração de Floriano, RO.

Em 16/8/1909 chegaram a um emaranhado de cabeceiras quase inextricável de três bacias: do Guaporé, do Tapajós e do suposto Jamari. Qual cabeceira e que rios? Um destes, que não pôde ser logo identificado, foi chamado rio da Dúvida, MT (rio Roosevelt, MT), a 647 km de Tapirapuã, MT provavelmente em 6/10/1909. Em 25/10/1909 partiram as três turmas resultantes da divisão da coluna exploradora: uma regressou para o Juruena. A segunda, 14 homens, desceu o rio Pimenta Bueno, recém descoberto em canoa construída. A terceira, Rondon com 27 homens, continuou por montes e vales através da floresta rumo noroeste.

Em 26/11/1909 chegaram ao rio Urupá, afluente da margem esquerda do Ji-Paraná, e não ao Jaci-Paraná como planejado (por erros de levantamentos de 1770 da primeira carta topográfica da Capitania (MT) (Fonseca, 1880) ou, da comissão de demarcação de 1781/82 de demarcação de limites, que efetuou o levantamento hidrográfico dos rios Madeira, Guaporé e Mamoré (Almeida Serra et alii, 1857; 1866: 390-96).

Em 8/12/1909, construída uma canoa, 13 homens doentes desceram o Ji-Paraná rumo ao Madeira. Rondon com outros 13 homens marchou para o poente; em 13/12/1909 a mais de $1.297 \mathrm{~km}$ de Cuiabá, MT, chegou ao rio Pardo, afluente da margem direita do rio Jamarí, onde encontrou o primeiro estabelecimento de seringueiro do Sr. Frota. Ainda por terra e por canoa Rondon e comandados chegaram ao Madeira em 25/12/1909, após 237 dias de sertão. 
Dirigiu-se para Santo Antônio, de onde partiu para Manaus em 6/1/1910.

O etnólogo Claude Lévi-Strauss, que saíra de Cuiabá em junho de 1938, em outubro já se encontrava junto do Posto telegráfico de Pimenta Bueno na confluência do rio homônimo com o Comemoração, onde é formado o JiParaná daí para jusante (Lévi-Strauss 2005:303-306 e 318).

Reunia (o posto) umas 20 pessoas: alguns brancos do interior, e índios diversos que trabalhavam na manutenção da linha Cabixiana do vale do Guaporé e Tupí-Cavaíba do rio Machado. Iriam me fornecer informações importantes. Umas se referiam aos Tupí-Cavaíba, ainda selvagens que, a julgar por antigos relatórios, se acreditava terem desaparecido totalmente (...). As outras eram relativas a uma tribo desconhecida que vivia, diziam, a vários dias de piroga pelo rio Pimenta Bueno. Concebi de imediato o plano de identificá-los, mas como? (Lévi-Strauss 2005:306-307).

Não há perspectiva mais exaltante para o etnógrafo que a de ser o primeiro branco a penetrar numa comunidade indígena. Em 1938, essa recompensa suprema só podia ser obtida em algumas regiões do mundo suficientemente raras (...). Portanto, eu reviveria a experiência dos antigos viajantes (...). Por menos conhecidos que fossem os índios do Pimenta Bueno, eu não podia esperar o choque sentido pelos grandes autores Léry, Staden, Thevet, que há quatrocentos anos puseram os pés no território brasileiro. O que viram na época, nossos olhos nunca mais avistarão... (Lévi-Strauss 2005:307-308).

Nas semanas seguintes, até novembro, Lévi-Strauss teve sua aspiração quase totalmente realizada, pois os Tupí mais arredios do rio Muqui não permitiram sua aproximação; contudo, conheceu uma aldeia dos Kepkiriwát (que, equivocadamente, chamou de Mundé), no alto Pimenta Bueno, e outras dos Kawahíb, localizadas junto a afluentes de ambas as margens do alto Ji-Paraná.

\section{De alguns povos Tupí contactados pela Missão Rondon entre 1909 e 1915 e pelo etnólogo Claude Lévi-Strauss em 1938}

\subsection{Os Kawahib (Pauaté)}

Todos os dados a seguir foram extraídos das cinco fontes citadas abaixo; os transcritos estão entre aspas, com código das obras entre parênteses (neste trabalho). 
— Rondon (MR): [1916] 2003:204, 209-214;

— Rondon e Faria (RF): 1948:18-21, fig. 24 [croqui p.182], fig. 32 [croqui p. 89], fig.33 [croqui p. 201];

- Roquette-Pinto (RP): 1950: Carta Etnográfica de Rondônia, encarte p. 22-23;

— Claude Lévi-Strauss (LSa): [1955] 1966:300-341;

- Claude Lévi-Strauss (LSb): [1994] 2001:164-213.

Posição geográfica: "A tribo que habita o curso superior do Ji é de origem Tupí. Rondon conseguiu entabular relações com ela e visitou as aldeias de três dos seus grupos: os parna-uats, taquateps e ipot-uats." (MR 211); (RF, fig. 24 [croqui p.182], fig. 32 [croqui p. 89]).

Identificados por Aryon D. Rodrigues como do Tronco Tupí, Família linguística Tupí-Guaraní, subgrupo: Kawahíb.

No momento em que Rondon tomou contato com os TupíCavaíba, os Takwatip, sob o impulso de um chefe ambicioso e enérgico, estavam alastrando sua hegemonia por vários outros bandos. (LSa 317).

O que transcrevemos a seguir reflete bem os exageros sobre a Amazônia, nos quais os mais desavisados muitas vezes creem piamente:

Após meses passados nas solidões quase desérticas do planalto, os companheiros de Rondon ficaram maravilhados com os "quilômetros" (mas a linguagem do "sertão" emprega de bom grado as hipérboles) de plantações feitas pelos índios de Abaitará na floresta úmida ou nos "igapós", margens inundáveis, e graças às quais estes puderam abastecer sem problemas os exploradores que até então tinham vivido sob a ameaça da fome (LSa 317).

Para uma avaliação bastante real da cobertura florestal de então (hoje com poucos relictos), formações rochosas expostas e topografia, junto do rio Ji-Paraná e seu afluente Pimenta Bueno, do alto e médio curso, ver imagens em LSb 168-171, 189, 192-193, 206-207, 210-213.

Relações: "São inimigos dos kepikiri-uats, aos quais guerreiam; e quando os apanham, cortam-lhes a cabeça" (MR 211).

Habitação: "Constroem ranchos com cobertura de duas águas, tendo cumeeira e seis esteios, mas sem paredes. As suas aldeias são relativamente grandes; cada qual conta mais de 50 habitantes." (MR 211, com imagens em LSb 191 à direita e 194 superior). 
Lévi-Strauss em 1938 confirma a existência desses grupos genericamente denominados Kawahíb, com imagens em LSb 190, 194-201, aproximadamente nas mesmas posições referidas por Rondon, junto aos afluentes de ambas as margens do alto Ji-Paraná, sendo que os Taquatep de 1913 seriam os Takwatip de 1938; veja o croquis de situação LSb 166 esquerda inferior.

O mais importante desses estava instalado no curso superior do rio Machado, a dois dias de marcha a partir da margem esquerda, e num afluente secundário, o igarapé do Leitão. Era o bando (...) Takwatip "do bambu" (...) que eram comandados pelo chefe Abaitará. Do mesmo lado do rio, ao norte, um bando desconhecido, a não ser pelo nome do seu chefe, Pitsará, ao sul no rio Tamuripu, os Ipoteuate (nome de um cipó), cujo chefe se chamava Kamandjar'a; depois, entre este 'último rio e o igarap'e do Cacoal, os Jabutif'ede ("gente da tartaruga"), chefe Maíra. Na margem esquerda do Machado, no vale do rio Muqui, residiam os Paranauáte ("gente do rio"), que continuam a existir (...) e, um pouco mais ao sul, no igarapé Itapici, um outro bando desconhecido (conforme informes de seringueiros em 1938) conversando com os Tupí-Cavaíba civilizados do posto de Pimenta Bueno, consegui ampliar essa lista de nomes (de bandos) fazendo-os chegar a uns vinte. (LSa 316).

(...) Rondon convenceu os Takwatip a transferir sua aldeia para a margem direita do Machado, para local ainda hoje [1938] indicado como Aldeia dos Índios, diante da foz do rio São Pedro $\left(11,5^{\circ} \mathrm{S}\right.$ e $\left.62,3^{\circ} \mathrm{O}\right)$ no mapa (...) $1 / 1.000 .000$ (...) para contar com a colaboração dos índios como canoeiros (...) peritos navegadores em suas leves naus de casca de árvore. (LSa 317).

Ainda me foi possível obter uma descrição dessa nova aldeia, hoje desaparecida. Como notara Rondon no momento de sua visita à aldeia da floresta, as cabanas eram retangulares, sem parede, consistindo num teto de pindoba de duas águas sustentado por troncos fincados na terra. Umas vinte cabanas (de cerca de quatro metros por seis) estavam dispostas num círculo de vinte metros de diâmetro, em torno de duas habitações espaçosas (dezoito metros por quatorze) ocupadas, uma por Abaitará, suas mulheres e seus filhos pequenos, outra por seu filho caçula, casado [corrijase: seu filho mais novo casado, conforme a tradução inglesa: Atheneum, New York, 1963:329]. Os (...) solteiros viviam, como o resto da população, nas cabanas periféricas (...). Havia diversos galinheiros no espaço desocupado entre as habitações centrais e as do contorno. (LSa 317). 
Estamos longe das amplas ocas Tupí descritas pelos autores do século XVI, mas a distância é ainda maior entre os quinhentos ou seiscentos moradores da aldeia de Abaitará e a situação atual. Em 1925, Abaitará foi assassinado. A morte desse imperador do alto Machado iria abrir um período de violências numa aldeia já reduzida, pela epidemia de gripe de 1918-20 a 25 homens, 22 mulheres e doze crianças. No mesmo ano de 1925, quatro pessoas (entre elas o assassino de Abaitará) foram mortas. Pouco depois os sobreviventes resolveram abandonar a aldeia e se dirigir (...) para o Posto de Pimenta Bueno; em 1938 o efetivo compunhase de cinco homens, uma mulher e uma menina (...). Podia-se acreditar que a história do Tupí-Cavaíba estivesse terminada (...) exceção feita de um grupo irredutível de Parnauate na margem esquerda, no vale do rio Muqui. (LSa 317-318).

Entretanto, ao chegar a Pimenta Bueno, no mês de outubro de 1938 , fiquei sabendo que, três anos antes, um grupo desconhecido de Tupí-Cavaíba aparecera no rio; foram revistos dois anos depois e o último filho sobrevivente de Abaitará (...), instalado em Pimenta Bueno, fora a aldeia dele isolada em plena floresta, a dois dias de caminhada da margem direita do Machado e sem nenhuma trilha que levasse até lá. (LSa 327).

De vez em quando nosso guia debruçava-se à beira de sua trilha invisível para levantar com um gesto célere uma folha e assinalar-nos, debaixo, uma lasca lanceolada de bambu fincada obliquamente no chão, afim de que um pé inimigo ali se cravasse. Essas engenhocas são chamadas de min pelos Tupí-Cavaíba, que, assim, protegem as redondezas de sua aldeia (...). Durante a tarde atingimos um 'castanhal' (...) Ali estava acampada a população da aldeia (...). Contavam-se ao todo seis mulheres, sete homens, sendo um adolescente, e três menininhas. Nesse total havia, aliás, dois paralíticos dos membros inferiores (...). Lá pelo fim da tarde chegamos à aldeia dos grilos (...) dominando o estreito vale [do] igarapé Leitão, afluente da margem direita do Machado, onde se joga a alguns quilômetros a jusante da confluência com o Muqui. A aldeia consistia em quatro casas mais ou menos quadradas (...) paralelas ao curso do rio. Duas casas - as maiores - serviam de habitação (...); as suas outras (...) tinha o aspecto de galpões ou abrigos (...) a parede externa estava coberta de pinturas sumariamente executadas em vermelho e preto. As casas em nada se assemelhavam às habitações indígenas das tribos vizinhas. Quando Rondon descobriu os Tupí-Cavaíba, suas casas já eram quadradas ou retangulares, com telhado e duas águas. Além disso, a estrutura em cogumelo não corresponde a nenhuma técnica neo-brasileira. (LSa 327-328). 


\section{Sepultamento:}

Enterram os seus mortos no interior dos mesmos ranchos em que habitam. Para isso, fazem a sepultura por baixo da rede que pertencia ao que vai ser enterrado; depois da cova fechada, cobrem-na com muita cinza e põem-lhe ao lado, exteriormente, as armas, os enfeites de pernas e demais utensílios do morto. A rede é deixada tal qual como estava (...). (MR 213).

Recipientes em cerâmica e cabaça:

A sua cerâmica apresenta igualmente uma novidade, de atendermos ao emprego dado em geral pelo silvícola aos objetos de barro. De fato, não se limitam estes índios a fabricar panelas de vários tamanhos, vasos para fermentar bebidas, potes para transportar água e outros para conservar no interior das casas (MR 212, com imagens LSb 190 e 191). Mas com o mesmo material fazem buzinas de diversos tamanhos, das quais conseguem tirar sons parecidos com os que produzem as usadas pelos nossos caçadores. Com tais instrumentos transmitem sinais a distâncias consideráveis, durante os combates (...), ou avisarem (...) de que se estão aproximando, quanto às pessoas que a vão visitar. (MR 212).

\section{Agricultura:}

Faziam plantações de milho, das muitas variedades nativas do Brasil, de mandioca (consumida também na forma de beiju, MR, 204), amendoim, algodão, banana, mamão, etc., e também de pimenta, que muito apreciam e comem em grande quantidade. (Obtidas talvez dos quilombos do Guaporé (Guaritizé)). Não cultivam o fumo e sentem por ele (...) aversão. (MR 213). Imagem do espaço de roça desativada ou em repouso (LSb199). Feijões, pequenos inhames, batatas doces. Os indígenas complementavam esses recursos com a coleta de produtos silvestres. Assim, exploravam uma gramínea da floresta, da qual amarravam várias hastes pela ponta superior, de modo que os grãos caídos se acumulassem em montinhos. Esses grãos são aquecidos numa chapa de cerâmica até que estourem, como as pipocas cujo gosto lembram. Enquanto o cauim cumpria seu ciclo complicado de misturas e fervuras, mexido pelas mulheres com conchas feitas de meias cabaças, eu aproveitava as últimas horas do dia para examinar os índios. (LSa 331).

\section{Caça, pesca, coleta e bebidas:}

Nas pescarias empregam os meios usualmente conhecidos dos nossos silvículas, inclusive o jiqui e o timbó; (...) nas águas correntes, constroem represas, com (...) resultados análogos aos 
que obtêm quando operam em lagoas (RM 213). (...) vasos para fermentar bebidas (...) (MR 212).

Sem dados acerca da caça e da coleta.

Transporte aquático:

Mas o traço mais importante do grau de civilização alcançado por estes índios consiste no conhecimento que eles têm da navegação. Desde Diamantino até o Ji, não encontrou Rondon outra nação que soubesse, como esta, construir e utilizar embarcações para suas travessias por água. (...) os habitantes do Ji-Paraná são peritos canoeiros e, com suas leves pirogas de casca de jatobá, de jequitibá e doutras madeiras, dominam o curso superior do seu rio e os respectivos afluentes. (MR 213).

Vestimenta e tecelagem:

Os homens vestem uns calções que fazem lembrar aqueles a que nos referimos, aludindo aos trajes nacionais dos parecis. (MR 211). Única vestimenta, o estojo peniano cônico (...) e as bordas laterais são costuradas com uma agulha de madeira e linha vegetal. (LSa 331). As mulheres usam tangas tecidas de algodão. (MR 211). Além da cinta de algodão as mulheres usavam faixinhas fortemente apertadas em volta dos pulsos e dos tornozelos. (LSa 331; LSb 190 esquerda, 196-199). Com o algodão fazem também as redes em que dormem e umas faixas que as mulheres passavam dum ombro para o flanco oposto, e lhes servem para carregar as crianças. (MR 212).

Adornos:

Usam, como os demais indígenas, muitos colares de cocos, sementes, dentes e unhas de animais, e enfeites de penas vistosas; mas os seus artefatos deste gênero são mais variados, mais artísticos e mais bem acabados do que os dos kepikiri-uats e os de todos os índios da mesma região. O que, porém, constitui uma novidade desta nação é o hábito, que nela se encontra, de serem as aves de que se tiram as penas para os ornatos conservadas vivas nas aldeias. Para tal fim possuem, além das araras, jacamins, mutuns e pavões-silvestres que, juntamente com porcos-domato, cutias, antas, etc., vivem domesticados nas malocas, alguns outros pássaros - como certo gavião grande, dotado de chifre e conhecido no sertão pelo nome de guanu — presos em gaiolas e ali cuidadosamente alimentados. (MR 212).

Imagens de 1938 mostram as mulheres e meninas somente com colares: "colares de dentes de anta ou de plaquinhas de osso de veado." (LSb 190191, 196-199 e 201; LSa 331). 


\section{Pinturas corporais:}

Além dos colares (...) eles se enfeitam, pintando as faces, as mãos e os pés com urucum e com o genipapo. (MR 212). Seus rostos eram tatuados com o suco preto do 'jenipapo': nas faces uma linha grossa oblíqua, indo do lóbulo da orelha até a comissura dos lábios, marcada por quatro tracinhos verticais e, no queixo, quatro linhas horizontais superpostas, cada uma enfeitada em baixo com uma franja de estrias. (LSa 331).

Cabelos:

(...) uns e outros deixavam crescer os cabelos, raspando-os um pouco na frente, de jeito a darem a aparência de possuírem testas elevadas e amplas. As mulheres trazem-nos amarados ao alto da cabeça, mas não repuxados, antes caindo com arte, sobre a nuca. (MR 211 e 212). Os cabelos, geralmente curtos, eram quase sempre alisados com um pente de desembaraçar ou um instrumento mais fino, feito de pauzinhos de madeira amarrados com fio de algodão. (LSa 331); imagens de 1938 revelam cabelos curtos, sem cuidados, e somente Muruabai parece apresentar a fronte raspada, mas somente na imagem 197 (LSb).

\section{Miscelânea:}

A Aldeia dos Grilos (...) As habitações estavam quase vazias. Notávamos as redes de barbante de algodão, algumas panelas de barro e uma bacia para secar no fogo a polpa de milho ou de mandioca, vasilhames de cabaças, almofarizes e pilões de madeira, raladores de mandioca de madeira incrustada de espinhos, peneiras de vime, buris de dentes de roedor, fusos, alguns arcos com cerca de 1,70 m de comprimento. As flechas eram de vários tipos, fossem de ponta de bambu-lanceolada para a caça, ou cortada em ziguezague - fossem de pontas múltiplas para a pesca. Por último, notavam-se alguns instrumentos musicais: flautas de Pã de treze tubos e gaitas escocesas de quatro orifícios. (LSa 331).

À noite Lévi-Strauss foi homenageado pelo cacique com: "cauim e um ensopado de feijões com pimenta, uma cuia com sal indígena, água marrom tão amarga que o cacique também provou para tranquilizá-lo.” (LSa 332).

Pela manhã um dos homens de Lévi-Strauss adentrou a floresta para caçar algumas pombas. Logo depois um estampido e fortes gritos: por um descuido o caçador alvejou a si mesmo. Ele apoiara a mão sobre a saída do cano e a arma disparara. 
Três dedos estavam quase seccionados, e a palma da mão parecia esmigalhada (...) Três dias depois o confiamos ao médico (...). A ferida estava a salvo de uma gangrena, pois os vermes tinham pouco a pouco comido as carnes putrefatas (...) um mês de intervenções cirúrgicas, Vellard restituiu a mão, aceitável para Emydio (...). (LSa 333).

Geralmente tais incidentes encerram as pesquisas apesar de serem considerados "um incidente banal da vida no sertão." (LSa 333). E assim terminou a pesquisa de Lévi-Strauss junto aos Tupí-Kawahíb.

\subsection{Os Kepkiriwát $(\dagger)$.}

Todos os dados a seguir foram extraídos das três fontes citadas abaixo; os transcritos estão entre aspas, com código das obras entre parênteses (neste trabalho).

— Rondon (MR): [1916] 2003:203-210;

— Rondon e Faria (RF): 1948:18-21, fig. 24 [croqui p.182];

— Roquette-Pinto (RP): 1950: Carta Etnográfica de Rondônia, encarte p. 22-23.

- Claude Lévi-Strauss (LSa): [1955] 1966:300-341;

- Claude Lévi-Strauss (LSb): [1994] 2001:164-213.

Posição geográfica:

Os kepikiri-uats constituem um povo bastante numeroso, que se distribui por muitos grupos, todos localizados no vale do rio Pimenta Bueno, a que dão nome - Djaruêreb. (MR 203); [também conhecido como Apediá]; (RF) fig. 24 [croqui p.182]. O Coronel Rondon visitou as suas aldeias e esteve nos grupos denominados xaramein uapurutá, bicop-uap e barepit. Em 1938 foi localizada uma aldeia, no alto Pimenta Bueno: Na tarde do quinto dia (de piroga desde o posto de Pimenta Bueno), uma piroga estreita atracada à margem assinalou nossa chegada. (LSA 312).

Ela se compunha de três cabanas e foi visitada por Lévi-Strauss, tendo resultados vários registros gráficos apresentados em LSb 166. "Os índios que designavam a si próprios com o nome de Mundé eram os prováveis remanescentes de uma população outrora numerosa, chamada Kepkiriwát." (LSb 167). Segundo Rodrigues esse termo Kepkiriwát não é Nambikwára, mas sim da família linguística Tuparí, subgrupo Kepkiriwát. 
A aldeia indígena ficava a um quilômetro mais para dentro: roça de uma centena de metros na sua maior extensão, ocupando uma clareira ovóide, onde se erguiam três cabanas coletivas, em forma hemisférica, por cima das quais a estaca central se prolongava como se fosse um mastro. As duas cabanas principais ficavam frente a frente, na parte larga do ovo, ladeando um terreiro de dança de terra batida. A terceira ficava na ponta, unida à praça por uma trilha que cruzava a roça. A população compreendia 25 pessoas, mais um meninote (...). (LSa 312 e 313; LSb 173).

Identificados por Aryon D. Rodrigues como do tronco Tupí, família linguística Tuparí, subgrupo Kepkiriwát (†).

Relações interétnicas: "É provável que tenham tido boas relações com os quilombolas do Guaporé, e principalmente com os do Guaratizé; entre eles, porém, não se encontram vestígios de cruzamento com negros." (MR 203). Parece que aconteciam incorporações interétnicas, pois: "um meninote (...) que falava outra língua (...) era um prisioneiro de guerra, tratado aliás como as crianças da tribo." (LSa 313).

Habitação: "Constroem palhoças cônicas, como as dos nambiquaras, mas diferentes destas por fazerem terminar a extremidade saliente da coluna central em ponta e não em forquilha." (MR 203 e figura p. 207). Fig. 19. Em 1938, Lévi-Strauss produziu um esboço de planta baixa com o uso do espaço interno, com várias fotos da aquitetura e da estrutura interna e externa (LSb $164,166,173-175,180,182$ e 183).

Armas:

Quanto às armas de que usam, pouco diferem das dos nambiquaras. Além do arco e da flecha. (MR 204, com imagem em LSb 185), (MR 204, com imagem em LSb 185), servemse nos combates de cacetes curtos; os chefes, nas ocasiões de festas ou solenidades da tribo, apresentam-se armados de clavas, espécie de espadas de madeira. São insígnias honoríficas que nunca se empregam nas lutas; os parecis e os nambiquaras têm o mesmo uso. (MR 204).

Cerâmica: "A sua cerâmica está bastante adiantada. Além de panelas de vários tamanhos, fabricam potes que parecem tinas, nos quais preparam bebidas fermentadas de amendoim e de milho." (MR 204 e figura p. 207). Figs. 19 e 20. Apesar das várias imagens de Lévi-Strauss em LSb ([1994] 2001), nenhuma revela qualquer exemplar de recipiente cerâmico dentro ou fora das cabanas. Cremos que nosso olhar clínico arqueológico sobre os cerca de 3.000 
negativos mencionados em LSb 23, revelaria muitos desses detalhes ainda não encontrados, para embasar ainda mais uma reconstituição razoável da cultura desses Tupí.

\section{Agricultura:}

As suas roças são muito maiores do que as dos nambiquaras, e as suas colheitas dão-lhes recursos muito mais abundantes de que as daqueles índios. Além dos feijões, mandiocas, milho e outros vegetais conhecidos dos nambiquaras, cultivam uma espécie de amendoim graúdo, diferente do nosso, e possuem grandes plantações de mamão e de banana. Guardam os produtos das suas lavouras em grandes paióis, e as menores porções dentro das suas habitações, em jiraus expressamente construídos para tal fim. (MR 204). As áreas de roça envolvem a aldeia, afastadas do rio, em meio à floresta (LSb 173).

Preparam os alimentos com muito mais asseio e cuidado do que os seus inimigos. Apreciam os beijus de mandioca e mais ainda os de milho, que aqueles não sabem fazer; mas para os assar colocam-nos sobre um pratos planos [beijuzeiro de cerâmica], tendo o cuidado de se servirem dum instrumento de pedra em todas as suas operações. Os beijus, depois de torrados, são servidos em bandejas de trançado de cipó ou taboca. (MR 204).

Para reduzir o milho a fubá e para misteres análogos a esse, usam dum processo inteiramente diverso do geralmente conhecido no Brasil. O pilão é o mesmo, a mão, porém, pesadíssima e terminada num grande bloco sem quinas, não se emprega para socar, mas sim para moer. O bloco representa o papel da mó, que nos moinhos se chama galga; o pilão representa o papel do pouso. A galga acha-se ligada a uma haste que, na posição de repouso, fica em vertical, para cima. Duas índias seguram a haste, afastam-na da vertical e imprimem-lhe uns movimentos de rotação tal que ela descreva, aproximadamente, um cone de revolução tendo para eixo a posição de repouso. O bloco ou galga, que se acha pousado sobre os grãos a triturar, arrastado por esse movimento da haste, executa no interior do pilão um movimento como de vibração, suficiente para o efeito desejado. (MR 205).

Caça, pesca, coleta e bebidas:

As caças e os peixes representam na sua economia o mesmo papel que na de todos os outros silvícolas; nas pescarias, como os nambiquaras, fazem uso do timbó. Bebidas fermentadas de amendoim e de milho. (MR 204). 
Tecidos:

Cultivam o algodão e com ele fazem vários tecidos, a começar pelas redes de malha em que dormem. Entre estas, há uma, muito comprida, na qual dormem duas pessoas, acomodadas em todo o seu comprimento, ficando as respectivas cabeças dos lados dos punhos de suspensão e os pés justapostos. (MR 204).

Vestimentas e adornos: Não usam roupa de espécie alguma (MR 205; LSa 313), mas

todos os homens usavam o estojo peniano cônico, parecido com os dos Bororo (...). Homens e mulheres traziam nos lábios botoques de resina endurecida que tinham o aspecto de âmbar, ou colares de rodelas ou placas de nácar brilhante, ou, ainda, de conchas inteiras polidas. Os pulsos, os bíceps, as barrigas da perna e os tornozelos eram apertados por faixinhas de algodão. Por último, as mulheres tinham o septo nasal furado para colocar um fuso feito de rodelas alternadamente brancas e pretas enfiadas e apertadas numa dobra rígida. (LSa 313). Os atilhos que amarram nos braços, nas pernas e na cintura; faixas que põem na cabeça e no pescoço levam enfeites de arminho de penas de grandes gaviões, de araras, de tucanos, e outras de cores brilhantes. Nos colares empregam os dentes de diversos animais e certos cocos pequenos, aperfeiçoados e brunhidos com auxílio de pedras, até ficarem com a casca muito fina e leve. Os enfeites aplicados nos lábios são geralmente de resina vegetal e terminam em ponta de espinho de ouriço. (MR 205).

As imagens de Lévi-Strauss ilustram com detalhes e clareza e mostram que esses adornos ainda eram confeccionados e usados em 1938 (LSb 175-187). Como visto, pouco ou nada mudou de 1913 a 1938.

\section{Droga:}

Fumo, não o usam em cigarro ou em cachimbos, nem para mascar; utilizam-se dele pelas narinas, sob a forma de rapé (...) à moda Kepikiri-uat. (...) primeiro o rapé (...) segundo um canudo (...) de perto de um metro; e a terceira, um parceiro.(...) Posto o rapé no canudo, um diante do outro, à distância determinada pelo tubo. O dono da pitada introduz numa das ventas a extremidade que lhe toca (...); e o seu ajudante, pela outra extremidade, com a boca, começa a soprar de leve, delicadamente (...) e o outro aspira fortemente o rapé, fazendo-o penetrar pelo sistema respiratório. (MR 205, 206 e figura p. 210; LSd 184). 
Mais detalhes sobre a agricultura, a construção das cabanas, a cozinha, o vocabulário, cuidados corporais pessoais dos Kepkiriwát, assim como do entusiasmo inicial e da impressão de vazio ou apenas de satisfação parcial de Lévi-Strauss, após uma semana entre esses índios são encontrados em LSa 313-315.

Ninguém, que eu saiba, reviu os Mondé [Kepkiriwát] desde a minha visita, a não ser uma missionária que encontrou alguns, pouco antes de 1950 no alto Guaporé, onde três famílias haviam se refugiado. (LSa 313-314).

O etnólogo Franz Caspar, como resultado de sua estadia em 1948 e 1955 entre os Tuparí, assentados no alto rio Branco, produziu a mais importante e completa monografia sobre esses, até o presente. Esse rio Branco que nasce próximo do rio Pimenta Bueno deságua na margem direita do Guaporé, junto à Fazenda Pau d'Óleo.

Segundo a FUNASA, em 2006, a população Tuparí era de 433 pessoas (Ricardo e Ricardo (orgs.) 2006:15).

\section{3 Os Arikém}

Todos os dados, a seguir, foram extraídos das três fontes citadas abaixo; os transcritos estão entre aspas, com código das obras entre parênteses (neste trabalho).

— Rondon (MR): [1916] 2003:217-22;

— Rondon e Faria (RF): 1948:18-21, (fig. 33) [croqui p. 201];

- Roquette-Pinto (RP): 1950: Carta Etnográfica de Rondônia, encarte p. $22-23$.

Posição geográfica:

Mais para o ocidente, no rio Jamarí, vivem os Ariquemes, que se distinguem pela sua índole pacífica. Desta nação não havia notícias: Rondon obteve as primeiras referências a ela em 1909, por seringueiros que se tinham estabelecido no curso inferior daquele rio. Em época anterior, haviam os bolivianos invadido as suas florestas, obrigando-os a refugiar-se para as altas cabeceiras (...). Aos bolivianos sucederam os brasileiros que (...) continuaram a persegui-los, expelindo-os com enorme mortandade das suas aldeias (...). Foi nestas tristes condições que Rondon os encontrou em 1913. (MR 219 e 220); (RF) fig. 33 [croqui p. 201]. 
Identificados por Aryon D. Rodrigues como do Tronco Tupí, família linguística Arikém.

Habitação: em forma de aldeia sem citar a quantidade dos abrigos. A fig. 34 [MR figura p. 217] dá uma ideia dum abrigo de planta oval, com teto de palha em forma de domo. As dimensões sugerem duas a três famílias por casa. Os indígenas, cerca de 15 entre adultos e crianças, homens e mulheres, sob influência da Missão Rondon estão quase todos vestidos, mas o cabelo característico. Obs.: essa maloca é uma das construídas na aldeia que Rondon mandou construir junto da estação telegráfica de Arikemes, para reunir todos os sobreviventes e dar-lhes proteção.

Vestimenta: Normalmente, todos andam nus.

Tecelagem: "Apesar das suas mulheres não usarem roupa alguma, sabem tecer o algodão, com o qual fazem redes de dormir." (MR 221).

Cerâmica: "possuem cerâmica muitíssimo desenvolvidas, fabricando vasos de grande capacidade, maiores do que os dos kepikiri-uats." (MR 221) Figs. 19 e 20.

Plantações: "Em geral os índios fabricam os seus ralos, cravando num pedaço de madeira mole espinhos de certos coqueiros, que os tenham bem resistentes. Os Ariquemes, porém, conseguem o mesmo resultado, mas com muito menos trabalho, servindo-se das raízes, eriçadas de pontas, das paxiubinha. Para triturar grãos, abrem em toras de madeira os cochos (...). Arranjam uma laje bastante pesada, com a forma geral de meio disco, cujo diâmetro e espessura sejam pouco menores do que o comprimento e a largura daquela escavação. Nesta colocam os grãos, e assentada sobre eles, pelo diâmetro, com a linha curva para cima [ou, para baixo?], a laje. Uma índia, com as duas mãos apoiadas sobre a parte superior daquela pedra, imprime-lhe um movimento de vaivém, fazendo-a oscilar para um e outro lado do plano vertical determinado pelo eixo do cocho. Obtém-se assim o rolamento da superfície longitudinal da pedra sobre as sementes que, comprimidas contra as paredes do cocho, são moídas." (MR 221). O moer sugere o cultivo do milho, e outros grãos; o ralar sugere a mandioca e outras raízes.

Obs.: Aos Arikém e seus antecessores atribuímos, hipoteticamente: a cultura da fase Pacatuba do $2^{\circ}$ estágio, como caçador-coletor e agricultor incipiente; a cultura da fase Massangana do $1^{\circ}$ subestágio, como caçadoragricultor e pré-ceramista do $3^{\circ}$ estágio; e da tradição Jamarí do $2^{\circ}$ subestágio como caçador-agricultor e ceramista (Miller et al. 1992) do $3^{\circ}$ estágio da sequência cultural Arikém. 


\section{Do Pré-Prototupí ao Proto-Tupíguaraní}

Os nomes concernentes ao Tupí (propostos abaixo), tanto linguístico como arqueológico, são apenas diferenciais, estando em aberto para modificações visando dirimir dúvidas e a levar ao entendimento mais amplo possível, inclusive interdisciplinarmente. Em 1987 só sugerimos os nomes que seguem (Miller 1987b, 36, rodapé). Mas, com base nas evidências arqueológicas com que contamos no presente, sugerimos empregá-los como nomes diferenciais, provisórios.

A existência de caçadores-coletores que fizeram do Abrigo do Sol/ MT, no Refúgio Guaporé, um sítio-acampamento, certamente ao menos ao longo dos últimos 20.000 e, provavelmente, de pelo menos até 25.000 anos (Albanese, 1977; Miller, 1974-75, 1977, 1983b p.281 nota 28, 1987a, fig. $29,2^{a}$ coluna periódica). Isso sugere a possibilidade da existência de uma "terra natal arcaica". Se é correto que a "terra natal arcaica" existiu, agora jaz subjacente à "terra natal"; seria provável que, dentre os caçadores-coletores lá existentes (Meggers e Miller 2003: 291-316; Miller et al. 1992: 32-46), se encontrasse o embrião do Pré-Prototupí, então:

No $1^{\circ}$ estágio, a "terra natal arcaica" comportaria hipoteticamente o embrião do Pré- Prototupí, pré-agrícola e pré-ceramista, um caçador-coletor simples, na Área Alto-Jiparaná (fig. 29 colunas periódicas 3 e 4), na transição do Holoceno Inferior-Médio ca. 7.000 a 6.000 anos a.P., coincidindo com o início do Optimum Climático, ou seja, de um clima gradativamente mais quente e mais úmido, que provocou a coalescência da floresta, com melhor caça e melhor coleta; isto se evidencia com as presenças das culturas Itapipoca e Pacatuba de caçadores-coletores simples junto ao médio/alto rio Jamari (fig. 29, 6 coluna periódica; Miller et al. 1992: 32-46).

No $2^{\circ}$ estágio, a "terra natal arcaica" durante o Holoceno Médio, ca. 6.000 a 5.200-5.000 a.P., no auge do Optimum Climático, teria um ambiente muito quente e muito úmido, com as matas adensando-se. Essa transformação ambiental provocou modificações nos recursos, com outras caças e outras coletas, diversas das características de ambiente misto de floresta aberta com cerrado ou savana. O habitat em modificação obrigou o indígena a adaptar-se. Os mais conservadores se deslocaram para ambientes assemelhados aos que já estavam acomodados. As diversificações ambientais levaram às diversificações comportamentais, que levaram o Proto-Tupí linguístico às dez famílias e dez culturas materiais em formação, em gradativa diferenciação, que explicaria as separações e choques, ainda neste estágio, entre os ramos de caçadores-coletores 
simples e caçadores-coletores com agricultura incipiente ainda sem cerâmica (Meggers e Evans 1973: 57-8), possivelmente provocadas mais pela maior ou menor velocidade de adaptação ou de mudança de estratégias e sucesso frente à nascente agricultura incipiente. Em alguns momentos do final desse estágio começaram a ocorrer os adventos da agricultura progressivamente menos incipiente (5.200-5.000 a.P.), pelo menos para quatro dos seis ramos do ProtoTupí linguístico ou Prototupí arqueológico, descritos a seguir:

1. O Pré-Proto-Tupíguaraní arqueológico ou Proto-Tupí-Guaraní, um dos 10 ramos do Pré-Prototupí arqueológico e Proto-Tupí linguístico, sem antecedentes arqueológicos neste estágio (ainda não há pesquisa sobre este caçador-coletor), mas certamente um iniciante na agricultura com base no $3^{\circ}$ estágio (fig. 29, $3^{\mathrm{a}}$ e $4^{\mathrm{a}}$ colunas periódicas; 5200-5.000 a.P.-1915 A.D.).

2. O Pré-Tupímondé arqueológico ou Proto-Mondé, ramo do Pré-ProtoTupí arqueológico e Proto-Tupí linguístico, sem antecedentes arqueológicos, nesse estágio (ainda não há pesquisa sobre este caçador-coletor), mas certamente um iniciante na agricultura com base no estágio 3 (fig. 29, $3^{\mathrm{a}}$ e $4^{\mathrm{a}}$ colunas periódicas; de 5200-5.000 a.P. a 1915 A.D.) onde aparecerá localizado na porção oriental, centrado no vale do Alto Roosevelt/Aripuanã, a oriente da Proto-Tupíguaraní. A subfamília menos desconhecida é a Mondé, cujo povo Paitér (ou Suruí), até o presente confecciona um vasilhame cerâmico que em nada lembra as cerâmicas das demais famílias Tupí.

3. O Pré-Proto-Tuparí arqueológico e Proto-Tuparí linguístico, sem antecedentes arqueológicos nesse estágio (ainda não há pesquisa sobre este caçador-coletor), mas certamente um iniciante na agricultura com base no estágio 3 (fig. 29, 3ª e $4^{\mathrm{a}}$ colunas periódicas; de 5200-5.000 a.P. a 1915 A.D.), onde aparecerá localizado na porção ocidental do altiplano do Alto-Jiparaná, centrado no vale do rio Apediá ou Pimenta Bueno, a ocidente e parcialmente interdigitado ao Proto-Tupíguaraní.

4. O Pré-Proto-Arikém arqueológico e Proto-Arikém linguístico, com antecedente arqueológico na cultura Pacatuba transicional, com caçadorescoletoresjunto aomédio/alto rio Jamari, que passamosa nomearhipoteticamente, nesse $2^{\circ}$ estágio, de Pré-Arikém, arqueologicamente correlacionados por estarem só eles nessa mesma área (fig. 29, 6 a coluna periódica; Miller et al. 1992: 32-46, de 6.00 a 5.130-5010 a.P. até 1915 A.D.).

No $3^{\circ}$ estágio, a "terra natal" se estende pelo terço final do Holoceno Médio e todo o Holoceno Superior, de 5200-5.000 a.P. até 1915 A.D. Para avaliar o que teria ocorrido de 5.000 a.P. a 1915 A.D., ou seja, ao longo de 4900 
anos de cultura Proto-Tupí, da "terra natal" até a porção sul da Faixa Costeira Tupíguaraní, levantamos 5 áreas-chave arqueológicas, com os impactos climáticos ocorridos, e elaboramos cinco colunas com as periodizações: $1^{\mathrm{a}}$ coluna, do Rio Grande do Sul, Litoral e rio Uruguai a oeste; $2^{\mathrm{a}}$ coluna, do Abrigo do Sol ao noroeste de Mato Grosso, distante $300 \mathrm{~km}$ ao sul da Área Alto-Jamarí/RO; 5 coluna, Pantanal do Guaporé e, 6 a coluna, o Médio Jamarí. Os poucos sítios-habitação Proto-Tupí com terra preta no Alto-Jiparaná, com cortes-experimentais, dentre centenas por pesquisar, pouco revelaram até o presente sobre impactos climáticos para serem periodizados na respectiva $4^{\mathrm{a}}$ coluna. Assim, criamos um cenário projetando sobre a $4^{\mathrm{a}}$ coluna os impactos severos observados na $1^{\mathrm{a}}$ coluna no Rio Grande do Sul, e $5^{\mathrm{a}}$ e $6^{\mathrm{a}}$ colunas em Rondônia. O resultado foi uma sequência em 5 fases alternadas, onde as $1^{\mathrm{a}}$, $3^{\mathrm{a}}$ e $5^{\mathrm{a}}$ fases correspondem a períodos de clima úmido, de boas colheitas, de subsistência garantida que, com o tempo, levaram a impactos pelas pressões por excesso de população; e as $2^{\mathrm{a}}$ e $4^{\mathrm{a}}$ fases correspondem, sem dúvida, a impactos de semi-aridez severos. Ambos os tipos de impactos provocam expansões, migrações. Mas ocorrem consideráveis perdas humanas ao longo das dispersões por impactos climáticos severos, pois estes podem afetar grande parte de um continente. Uma dispersão por semi-aridez reduz o potencial de sobrevivência, que atinge também as populações por onde a dispersão se produzirá, levando aos choques entre tribos estressadas.

As aldeias multiplicaram-se e, com o tempo e as reocupações, deixaram as terras pretas como testemunhos. Pela quantidade, nem todas foram ocupadas ao mesmo tempo. Uma distribuição de malocas é dada pelo mapa elaborado pela Missão Rondon (1948; fig. 24) com a presença de 50 malocas em 1913. A população total resultante pressionou a si mesma. O "remédio virou veneno", originando desentendimentos, re-acomodações, deslocamentos, expansões, migrações, com choques entre tribos pela posse das novas terras. Para o sucesso da posse, os deslocamentos deveriam ter sido feitos por contingente equivalente a várias aldeias ao longo dos deslocamentos, garantindo o sucesso das expansões e migrações que se dariam pelos rios com matas ciliares extensas, em cujas margens iriam sendo criados novos aglomerados de aldeias e roças. Foi uma época de fartura, até que o severo impacto climático da $2^{\mathrm{a}}$ fase reduziu tudo à semi-aridez. Essa severidade abrangeu ambos os hemisférios ca. 4400 a 4100 a.P. Para os atingidos, dificilmente houve um espaço bom para a sobrevivência. O Abrigo do Sol no Refúgio Guaporé, com imensos aquíferos, não revelou nada de impactante. Um sítio com cerâmica corrugada nas imediações revelou uma presença Proto-Tupíguaraní, seria 
uma rota de dispersão para o sul? Seria esse episódio da $2^{\mathrm{a}}$ fase a origem da procura pela terra sem mal, sempre mais para o sudeste e o sul? Se a partição do $3^{\circ}$ estágio em três fases de "vacas gordas" (clima úmido e quente) e duas de "vacas magras" (clima semi-árido e quente) estiverem corretas, então, na $1^{a}$ fase houve ca. 700 anos de clima quente e úmido. Com essas ponderações retomamos o $3^{\circ}$ estágio e descrição das colunas climáticas e culturais:

1. No $3^{\circ}$ estágio surge a Prototupí arqueológico ou Proto-Tupí linguístico , agora um caçador-agricultor-cerâmico, semi-sedentário e aldeado, com uma coluna periódica arqueológica entre 5.000 a.P. até 1915 A.D. (Mille et al. 1992, fig. 29, $3^{\circ}$ estágio), com 4900 anos contínuos de história da pré-história, particionada em 5 fases climáticas maiores.

A $1^{\text {a }}$ fase, 5.000-4.300 a.P., com ca. 700 anos de clima muito quente e muito úmido, biota coalescente, estável o suficiente para uma agricultura e subsistência com superávit; provocou um crescimento populacional desproporcional ao espaço físico disponível, resultando nas primeiras dispersões, encerrando assim o Optimum Climático.

A $2^{\mathrm{a}}$ fase, 4.300-4.000 a.P., com ca. 300 anos de semi-aridez severa, provocou dispersões desastrosas, pela continentalidade desse fenômeno.

A $3^{\text {a }}$ fase, 4.000-2.800 a.P., com ca. 1.200 anos de clima quente e úmido, não tanto como na $1^{\mathrm{a}}$ fase, leva à recuperação biótica, recomposição e crescimento populacional, que vai equilibrar com novas dispersões.

A $4^{\text {a }}$ fase, 2.800-2.500 a.P., com ca. 300 de semi-aridez, menos severa do que a da $2^{\mathrm{a}}$ fase, mas o suficiente para provocar outras dispersões;

$5^{\text {a }}$ fase, 2.500 (1915 A.D.) a.P., com ca. 2.405 anos, relativamente estáveis para a biota com crescimento moderado à estabilidade da população, teve pouca ou nenhuma dispersão populacional. Chegam os ibéricos, seus descendentes e seus germes; a morte e a deculturação e a degradação dos sobreviventes, ao longo dos séculos XVIII a XX, em 1909-15, no último recanto e refúgio, o do Alto-Jiparaná.

2. No $3^{\circ}$ estágio surge o Tupímondé arqueológico ou Tupí-Mondé ramo do Proto-Tupí arqueológico e linguístico (propostos). Agora, um caçador-agricultor-cerâmico, semi-sedentário e aldeado, mas por falta de pesquisas arqueológicas sobre todos os subgrupos, sua coluna periódica carece de informações, a não ser de sua existência no final do $3^{\circ}$ estágio. Etno-historicamente, aparece localizado na porção oriental, centrado no vale do Alto Roosevelt/Aripuanã, a oriente da Proto-Tupíguaraní (fig. 29, 3ª e $4^{\mathrm{a}}$ colunas periódicas). O subgrupo menos desconhecido é o Tupímondesuruí 
que até o presente confecciona seu vasilhame cerâmico que em nada lembra as cerâmicas das demais famílias Tupí.

3. No $3^{\circ}$ estágio surge o Tupítuparí arqueológico ou Tupí-Tuparí ramo do Proto-Tupí arqueológico e linguístico (propostos). É mencionado, como um caçador-agricultor-cerâmico, semi-sedentário e aldeado, mas por falta de pesquisas arqueológicas sobre todos os subgrupos, sua coluna periódica carece de informações, a não ser de sua existência no final do $3^{\circ}$ estágio, ainda com pouquíssimos antecedentes arqueológicos (figs. 19-22). Etnohistoricamente é descrito desde a Missão Rondon (1948, 2003). Por falta de pesquisas arqueológicas sobre todos os subgrupos, sua coluna periódica carece de informações, a não ser de sua existência no final do $3^{\circ}$ estágio, aparecendo localizado na porção ocidental do altiplano do Alto-Jiparaná, centrado no vale do rio Pimenta Bueno, a ocidente da Proto-Tupíguaraní (fig. 24, Quêpiquiriuáte, subgrupo do Tuparí; fig. 29, 3a e $4^{\mathrm{a}}$ colunas periódicas). O Tupítuparí que permaneceu ao lado da Proto-Tupíguaraní guarda alguns traços comuns com a Proto-Tupíguaraní, uma faixa corrugada incipiente ao redor da borda do vasilhame.

4. No $3^{\circ}$ estágio surge o Tupíarikém arqueológico ou Tupí-Arikém ramo do Proto-Tupí arqueológico e linguístico (propostos), com antecedente arqueológico concreto da cultura Pacatuba caçadora-coletora transicional para a Massangana, de caçadora-agricultora pré-cerâmica, transicional para a Tradição Jamarí caçadora, agricultora cerâmica, junto ao médio/ alto rio Jamari que hipoteticamente passamos, nesse estágio, a nomear de: Tupíarikém, linguística e arqueologicamente correlacionados por estarem sós etno-historicamente, nessa mesma área (fig. 29, 6 a coluna periódica; Miller et al. 1992:32-46). Antecedentes: a pressão da desigualdade crescente entre o modo de vida dos agricultores incipientes em expansão e os demais ramos constituídos de simples caçadores-coletores ( $2^{\circ}$ estágio), deve ter constrangido os últimos para outras áreas levando à desagregação do tronco Tupí com a separação entre as famílias (Meggers e Evans 1973:57-8). Uma delas a Proto-Tupíarikém uma das primeiras a se deslocar. Foi encontrada no centro da "terra natal" como caçadora coletora onde teria se instalado ao longo do médio Jamarí e foi daí que provavelmente surgiu a cultura Pacatuba Caçadora-coletora simples (Miller et al. 1992, fig. 29, 6 coluna).

5. A separação do Proto Tupímundurukú de perto do Proto-Tupíguaraní, e para fora da "terra natal", só deve ter ocorrido quando ambos possuíam os mesmos rudimentos da cerâmica pintada, ou seja, não antes de alguns 
séculos após a transição entre $2^{\circ}$ e $3^{\circ}$ estágios, ca. $5.070 \pm 66$ a. P., sugerido por exemplares cerâmicos pintados provenientes dos Mundurukú.

Enquanto que as famílias linguísticas do Tronco Tupí são bastante similares entre si, as cerâmicas das famílias e subgrupos, que as possuem, são parciais a extremamente diferenciadas umas das outras, podendo admitirse que elas não provêm duma mesma origem cerâmica, ou esta é muito mais antiga do que supomos no momento, ou algo agora inexplicável e muito rápido ocorreu. Elas foram desenvolvidas entre completa à relativa independência. Para tanto é necessário um distanciamento relativo, em tempo e espaço, delas entre si e da Proto-Tupíguaraní enquanto ainda eram pré-ceramistas (Meggers e Evans 1973), em meados do $2^{\circ}$ estágio, $6^{\mathrm{a}}$ coluna $6^{\mathrm{a}}$ coluna bem antes dos $5.070 \pm 60$ anos a.P. Então, a precoce família Proto Tupí-Guaraní ainda préceramista estaria iniciando no auge do Optimum Climático, uma agricultura incipiente que teria transformado o modo de vida dos grupos familiares de acampamentos nômades para tribos semi-sedentárias aldeadas, origem da terra preta.

\section{Hipóteses}

\subsection{Linguística, segundo Aryon Dall'Igna Rodrigues}

Rodrigues: Ramos linguísticos do tronco Tupí foram encontrados ao norte e sul do rio Guaporé. No lado brasileiro em Rondônia as famílias são conhecidas por Tuparí, Mondé, Ramaráma, Puruborá, Arikém, e TupíGuaraní. Do lado boliviano todas as línguas do Tronco Tupí pertencem à família Tupí-Guaraní. Devido à quantidade de famílias entre o rio Guaporé, o alto Madeira e o alto Aripuanã, foi assumido que o centro de dispersão do tronco Tupí deve ter sido em alguma parte desta região (Rodrigues 1958a).

Miller: Arqueologicamente, as cerâmicas corrugada e pintada indicadoras da tradição Tupíguaraní (Brochado et al. 1969, Chmyz, 1969, 1976) assemelham-se à existente dentro da região entre o Guaporé-Madeira e Aripuanã, que denominamos de tradição Proto-Tupíguaraní, porém mais antiga, com ca. 5.070 \pm 60 a.P. É derivada e evoluída por dispersão, expansão, difusão e migração deste centro, que desde o início ocupou as margens do alto rio Ji-Paraná, seus afluentes e o baixo curso dos maiores destes. Arqueologicamente esse centro é chamado de Área Alto-Jiparaná, entre a Cachoeira do Arregaço e os baixos cursos do Comemoração e Pimenta Bueno, cerca de $230 \mathrm{~km}$ entre os extremos. 
Rodrigues: “c) Digno de nota é o fato de quase todas as famílias linguísticas do tronco Tupí até agora reconhecidas se concentrarem na região do Guaporé, isto é, do alto Madeira, particularmente entre os rios Guaporé e Ji-Paraná (ou Machado). As famílias Arikém, Kanoê, Mondé, Ramaráma e Puruborá encontram-se exclusivamente nessa região, também a família Tupí-Guaraní acha-se ali bem representada (...)". Este fato sugere que talvez o centro de difusão do Proto-Tupí deva ser procurado na área do Guaporé. “e) Apesar de nos termos abstido de qualquer datação glotocronológica, (...) podemos avaliar a idade de todo o tronco linguístico Tupí em uns 5.000 anos (...) e da família Tupí-Guaraní em aproximadamente 2.500 (...).” (Rodrigues [1958a]1964, citado em Miller 1983:85).

Miller: Apesar de contarmos com datações ${ }^{14} \mathrm{C}$, desde 2001, só agora em 2007 elas estão sendo divulgadas pelas razões já apresentadas quanto à grande antiguidade em relação à Faixa Costeira. Agora que as aceitamos, surge um impasse quanto à data entre 3.000 e 2.500 anos a.P. atribuída à família TupíGuaraní. Com os trabalhos arqueológicos sendo intensificados em Rondônia, por vários empreendimentos, são possíveis novas datações a curto prazo e, se elas se situarem entre 4.000 e 5.000 a.P., estarão confirmando a antiguidade da tradição Proto-Tupíguaraní. A partir daí o conceito e paradigma de falante Tupí-Guaraní precisa ser reavaliado e reajustado.

Com a continuidade das pesquisas de linguística comparativa foram acrescentadas mais três famílias línguísticas às sete anteriores (1964), perfazendo dez famílias línguísticas para o tronco linguístico Tupí, com a seguinte designação: Arikém, Ramárama, Tuparí, Puruborá, Jurúna, Awetí, Mondé, Mundurukú, Mawé e Tupí-Guaraní (Rodrigues 1986). As quatro primeiras só em RO, a quinta e a sexta só em MT, a sétima também em MT, mas principalmente em $\mathrm{RO}$, a oitava e a nona só no AM e PA, e a décima em RO e outros estados e países.

Rodrigues, no artigo "Linguistic reconstruction of elements of prehistoric Tupí Culture" (a aparecer em 2010 em Festschrift em homenagem a Willem Adelaar, Leiden), apresenta o seguinte:

\section{The Tupi linguistic stock.}

The Tupí linguistic stock is one of the major genetic groups of indigenous languages in South America. It comprises ten linguistic families: 1. TupíGuaraní (TG), (...). The expansion of this family to the south and then to the east must have happened in two or three successive migrations most probably upstream from the Madeira river and then downstream from the Paraguai river 
(Rodrigues 2000, 2007a). The original split that gave rise to the Tupí stock probably started in the basin of the Madeira between the Aripuanã and Guaporé rivers, about 5,000 years ago (Rodrigues 1958, 1964, 1999) (p. 1)

(E.Th.M.) 1. Sim: A linguística e a arqueologia com datas ${ }^{14} \mathrm{C}$ estão correlacionando informações que estão começando a creditar ainda mais e confirmar algumas hipóteses quanto aos falantes Proto-Tupí e Proto-TupíGuaraní, e Proto-Tupíguaraní (arqueológico). Estão apoiando mutuamente expansões em sucessivas migrações (fig. 29 colunas $4,3^{\circ}$ estágio, fase 1 e seguintes), que teriam sido, de início dirigidas para o sul. É conhecido um sítio com cerâmica corrugada ao lado do Abrigo do Sol/MT dentro do

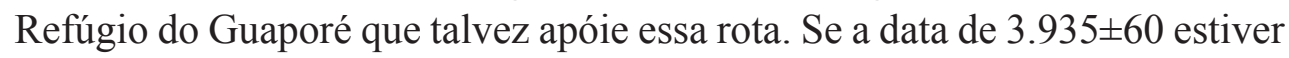
correta, a fase Itapuã da subtradição Pintada no Alto Uruguai/RS (Miller, 1969a) seria um dos primeiros, e mais distante, reassentamentos fora da "terra natal", como resultado do início da divisão original. Outrossim, as separações parecem já ocorrentes no $2^{\circ}$ estágio quando ainda eram caçadores coletores sem agricultura ou incipiente, sem cerâmica ou incipiente (fig. 29, coluna $4,2^{\circ}$ estágio).

\section{The antiquity of the Tupi Proto-language.}

The estimate of ca. 5,000 years for Proto-Tupí, the language spoken by a people whose splitting into several groups gave occasion to increasing linguistic variation that progressively came to constitute distinct languages, was not based on any correlation with archeological facts, nor on the results of biological research in human genetics (that did not exist for Amazonia fifty years ago), (...). However, the hypothesis of such a time depth for the Tupí stock in the Madeira basin was favorably received by archeologists working in Amazonia (Meggers e Evans, 1973) and by linguists and anthropologists interested in the ethnohistory of South America (among others, Urban 1992:91ff.). (p. 2).

(E.Th.M.) 2. Sim. Finalmente está começando a ocorrer essa possibilidade de correlação, como no texto acima. Os $5.070 \pm 60$ a.P. da tradição Prototupí está sugerindo que se os falantes Tupí-Guaraní são os autores dela então ela teria a mesma idade, e o Proto-Tupí seria ainda mais antigo do que a léxico-estatística sugere. Há um apoio arqueológico e suas datas quanto a uma maior antiguidade para o falante Proto-Tupí da "terra natal". Para os pesquisadores da Amazônia, que receberam favoravelmente as estimativas léxico-estatísticas, estas estão sendo apoiadas pelas confirmações das evidências arqueológicas associadas a datações 14C que devem sustentar 
uma hipótese de maior antiguidade ainda, tanto para o Proto-Tupí como para ao menos algumas de suas línguas incluindo a Proto-Tupí-Guaraní

3. Method (...).

\section{Purpose of this paper.}

My purpose here is to present the reconstruction of Proto-Tupí words with meanings that imply knowledge and activities associated with agriculture in Amazonia about 5,000 years ago. The reconstructed lexicon includes the word for the garden of manioc and others crops, the names for the digging stick and for cultivated and semi-cultivated plants, names for activities that used to accompany agriculture, such as pottery and weaving, and names referring to villages or stable houses and pieces of household equipment such as the hammock. Some verbs for cooking and roasting were also reconstructed. It is true that roasting is a technique common to peoples who are only hunters and gatherers, but cooking presupposes the presence of pottery, which is normally associated with the presence of agriculture and stable residence. Reconstruction of words revealing others contemporaneous cultural elements are also presented, not only elements of material culture, but some social usages too (p.3).

(E.Th.M.) 4. São animadoras as conclusões a que estão levando os resultados das reconstruções linguísticas, combinadas com a terra preta antropogênica arqueológica. Ambas se apóiam e se completam quanto à antiguidade linguística e cultura material, quanto à existência da agricultura, do vasilhame cerâmico, machados líticos, meios e processamento de alimentos, e outros recursos, de matéria-prima biótica ou orgânica, que não sobrevivem ao intemperismo químico. Aarqueologia aguarda da linguística informações quanto à decoração plástica (corrugada, particular ao falante da língua Tupí-Guaraní tanto da "terra natal" como da Faixa Costeira; para a tradição Prototupí da "terra natal" como da tradição Tupíguaraní da Faixa Costeira). O mesmo é aguardado sobre a pintada na cerâmica do falante Tupí (tradição Prototupí e Tupíguaraní), do falante Tupí-Tupínambá: os ramos Proto-Tupínambá e Tupínambá. O mesmo quanto aos seus motivos, que lembram cestarias, grosso modo, de todas as tradições com cerâmica pintada do Macro-Tupí, no $1^{\circ}$ subestágio do $3^{\circ}$ estágio e retroativamente, do $1^{\circ}$ e $2^{\circ}$ estágios, domínio de caçadores coletores sem agricultura ou incipiente, sem cerâmica ou incipiente.

5. Conventions. (...).

6. Languages and sources. (...).

7. Reconstructed Proto-Tupí cultural terminology. (...). 


\section{Concluding comments.}

The presence of reflexes of the same name for the cultivated patch of land in nine of the ten linguistic families of the Tupí stock is in itself a strong indication in favor of the recognition of the practice of agriculture among the speakers of Proto-Tupí language. Other direct evidence is the occurrence in languages of both main Tupí branches, the western and the eastern, of the same word for the digging stick, the main instrument used for planting. Essential for clearing garden plots is the ax, whose old name is well preserved in nearly all linguistic families of the stock (but it is true that the ax is also made and used by peoples who are not agriculturists, but rather hunters and gatherers). The common heritage of the name of the basic crop of most Tupían peoples, manioc, is another indication, together with secondary crops like sweet potato and carás (kinds of yam). Although corn is cultivated by most, if not all Tupían peoples, the diversity of attested names did not permit to reconstruct a common word for this crop. However a well-attested old word for poundind may be due to a strong presence of corn in the fare of the Proto-Tupí people. Normally correlated with agriculture is pottery, well attested in the proto-language by the reconstruction of the word ${ }^{* *}$ wa/e) for earthenware in almost all families of the Tupí stock. The same may be said of stable settlement in villages with common designations for village, house, door and the main piece of indigenous household equipment in Amazonia, the hammock. If the evidence for agriculture at the time depth reached by the reconstruction of Proto-Tupí words is well founded, the same is of course true for other cultural elements revealed by other words ascertained for the pre-historic language. However, one should keep in mind that the time depth of about 5,000 years for Proto-Tupí still needs to be confirmed by extralinguistic evidence, especially archeological evidence from the area where most probably the Proto-Tupí people lived berfore the successive splits that gave rise to the different linguistic families we know today.

8. A presença do falante Proto-Tupí e das culturas materiais do Prototupí e outros (sugestivamente: do Prototuparí, Tupímondé, Proto-Tupíarikém, etc.), na "terra natal"; e refúgios correlatos à mesopotâmia Guaporé-Madeira e Aripuanã, desde ca. 5.000 a.P, já é estimado linguisticamente por Rodrigues, desde 1958 (Rodrigues, 1958) e arqueologicamente aceito por Miller desde 1983 (Miller, 1983) e confirmado pelo 14C desde 2001. Conhecimento este complementado etno-historicamente (Roquette-Pinto, 1917; Rondon e Faria 1948; IBGE 1981; Rondon 2003). Segundo a reconstituição linguística que Rodrigues vem realizando, há fortes indicadores de que praticamente todos 
os povos das famílias linguísticas praticavam a agricultura e a cerâmica. Como no presente, as poucas datações só cobrem algumas evidências arqueológicas e somente da tradição Prototupí, correlato ao falante ProtoTupí, uma confirmação mais ampla levará alguns anos ainda. Como a cultura Prototupí está alojada entre as hipotéticas Tupari a oeste, e a Mondé a leste, não é impossível uma cópia de conhecimentos pró-agricultura; mas quanto à cerâmica, todas as três a possuem, porém cada uma a seu modo, cuja antiguidade só é conhecida para a localizada na "Área Alto-Jiparaná" acima apresentada, onde os falantes do Proto-Tupí e a correlata da cultura material, a Prototupí viveu antes e durante as expansões, migrações e dispersões até a chegada e testemunho da Missão Rondon.

\subsection{Arqueologia:}

9.2.1 Betty J. Meggers e Clifford Evans (1973), com base em Rodrigues (1958a), informam:

SINOPSE - (...) A coincidência entre indícios arqueológicos e linguísticos de uma extensa dispersão de povos há cerca de 3.000 anos, requer explicação; ocorrendo por outro lado evidência segura de uma mudança climática verificada entre 3.500 e 2.000 anos passados, de tal rigor que causou pronunciada redução na área coberta por matas e sua substituição por cerrados ou savanas. É provável que o aumento de aridez tenha afetado a tal ponto as fontes de subsistência, provocando extensos deslocamentos populacionais." (p. 51). "Dados paleoambientais são relevantes porque as mudanças climáticas podem afetar drasticamente as fontes de subsistência, o suficiente para alterar as adaptações culturais ou provocar migrações da/para a região." "Outrossim, as alterações climáticas tendem a afetar grandes áreas e suas influências não podem ser precisamente avaliadas se for também restrito o propósito da análise. (p. 53).

(E.Th.Miller) Certamente: três das colunas periódicas das áreas-chave - 1, RS-litoral, 5, RO - Pantanal do Guaporé, e 6, Médio Jamarí (fig. 29) comprovam ao menos duas fases de transição climática, com semi-aridez. Uma de âmbito global severa entre ca. 4.400 e 4.100 a.P., para semi-aridez o suficiente para eclipsar o Optimum Climático. Com a retração da floresta contínua para mata ciliar nas baixadas e planícies de depressão do Guaporé, junto às fontes de água subsistentes, dando lugar às matas abertas e cerrados ou savanas, e a grandes incêndios. Esse caos ambiental restringiu ainda mais os meios de subsistência por toda parte especialmente nos sambaquis 
da fase Sinimbu. Para onde poderia se deslocar uma população com base mais na agricultura, já com pouca caça, pesca e coleta, sem animais de criação? Provavelmente o modo caçador-coletor ancestral foi de ajuda na sobrevivência, mas para apenas uma minoria. Com base na coluna 2 Refúgio Guaporé/MT (e por analogia noutros refúgios) os sedimentos do Abrigo do Sol sugerem alterações climáticas mais suaves, permitindo a ocupação local, como no passado. Parece que alguns dos aquíferos da encosta oeste do Chapadão dos Parecis, que dão origem aos afluentes da margem direita do Guaporé, não deixaram este totalmente a seco, sustentando os já reduzidos grupos humanos. Depois dos 4.100 a.P., como comprova o ressurgimento do Pantanal do Guaporé, ocorreu a reocupação dos sambaquis por ceramistas (fase Bacabal) (fig. 29, coluna 5).

Entre ca. 2.800 e 2.600 na "terra natal", e 2.400 e 2.100 a.P. no nordeste do Rio Grande do Sul, respectivamente nas colunas 6 e 1, foram registrados outros eventos de semi-aridez pouco severa, mas o suficiente para levar a novas dispersões, ao menos no sudoeste da Amazônia e no sul do Brasil.

Apesar da distância do litoral para este cenário centro-continental, geralmente as fases de semi-aridez coincidem com as fases de regressão marinha (recuo marinho) e vice-versa; as fases de climas muito úmidos coincidem com a transgressão marinha (avanço do mar), o que tem relação com a água contida principalmente nas geleiras polares (Suguio 1999). O excesso de calor e umidade também causa impactos negativos, sendo um deles o excesso de população humana, situação agravada pelo excesso de biodecompositores, nociva para a preservação dos alimentos. Também o equilíbrio provoca deslocamentos populacionais, sem condições de subsistência por onde quer que se desloquem, inclusive entre divisores de bacias, o que sob semi-aridez seria fatal. São duas condições extremas a serem consideradas por aqueles que pretendam pesquisar sítios arqueológicos para determinar as rotas de dispersão ao longo dos milênios, quando e onde se processou a maioria das diferenças tipológicas, ao menos as da cultura material.

(B.J.M. e C.E.) “A quantidade de diferenciação linguística entre essas famílias implica que os falantes haviam perdido o contato entre si cerca de 5.000 anos atrás. Apenas uma das sete [hoje dez] famílias, a TupíGuaraní, tornou-se muito diferenciada internamente durante os milênios subsequentes. (...) A antiguidade da separação (cerca de 5.000 anos) sugere que a diferenciação começou quando os falantes eram ainda pré-agricultores 
e não fabricavam cerâmica. Portanto, é possível que a identificação da "terra natal" jamais possa ser verificada arqueologicamente. Embora as mais antigas cerâmicas conhecidas do Novo Mundo tenham uma antiguidade de cerca de 5.000 anos, elas foram apenas registradas no litoral do Equador e norte da Colômbia (Ford 1969).” (p. 57).

(E.Th.M.) Essa interpretação de Meggers e Evans está por ser comprovada. Segundo Rodrigues, do ponto de vista da linguística histórica ou diacrônica, uma proto-língua é concebida como uma unidade, num momento que antecede a cisão ou as sucessivas cisões do grupo étnico do qual descendem os falantes das línguas atuais. Se, no nosso caso, a reconstrução do Proto-Tupí inclui evidências da prática da agricultura e da cerâmica, não há por que supor a associação do Proto-Tupí com uma fase anterior, nãoagrícola e não-ceramista. Ainda não houve, até onde sabemos, nenhuma tentativa de associar evidências lexicais com práticas pré-agrícolas e précerâmicas, como, por exemplo, o corte de madeira ou de fibras mediante instrumentos líticos, ósseos ou vegetais, assim como a raspagem e polimento de superfícies, etc., práticas essas que certamente devem ter existido desde antes do desenvolvimento da agricultura e da cerâmica e que continuaram existindo após esse desenvolvimento.

(B.J.M.e C.E.) “A escassez de informações arqueológicas do sudoeste da planície amazônica não permite, no momento atual [i. é, 1973], especificar o local e a data em que alguns falantes Tupí-Guaraní começaram a fabricar cerâmica Pintada." (p. 58).

(E.Th.M.) Agora, já dispomos de algumas datações ${ }^{14} \mathrm{C}$ e, se a mais antiga, a $10 \mathrm{~cm}$ acima da base do sítio RO-JI-15: Urupá, com ca. 5.070 60 anos a.P., for válida, então tanto os pintados com o vermelho ou preto sobre superfície simples (ausente no Tupíguaraní), como sobre engobo vermelho ou branco, todos têm essa idade. O intemperismo químico alterou bastante as superfícies como um todo, inclusive as pintadas. Ocorrem amostras onde o branco tem aparência acinzentada numa porção; se a amostra abranger só uma ou outra porção do fragmento, será difícil visualmente definir a cor original, ou se foram empregadas as cores branca e preta numa composição. Como o percentual pintado é muito baixo e muito pouco foi escavado, só no futuro serão possíveis as elucidativas seriações quantitativas.

(B.J.M. e C.E.) (...) "cacos corrugados (...) no noroeste da Argentina (...) 700 a.C. tornaria esta técnica disponível antes da dispersão dos falantes Tupí-Guaraní em direção leste". 
(E.Th.M.) Na Área Alto-Jiparaná, RO, o corrugado e outras técnicas plásticas já estavam lado a lado com a pintura já desde ca. 5.070 \pm 60 a.P.

9.2.2 Pedro I. Schmitz (1991), com base em Migliazza (1982), informa:

Migliazza (1982) estabeleceu a origem do tronco Tupí entre os rios Ji-Paraná e Aripuanã afluentes do rio Madeira pela m.d., baseado no pressuposto de que o lugar de origem do tronco é aquele com o maior número de famílias linguísticas aparentadas (Dyen, 1956). Com base na glotocronologia, a origem deste tronco é avaliada em torno de 5.000 anos atrás (p. 300-301; mapa 1, p. 324).

(E.Th.M.) No "Mapa 1", o tronco Tupí é representado concentrado entre a margem esquerda do médio curso do rio Ji-Paraná e a margem direita do médio rio Roosevelt. Esse espaço, na verdade, fez e ainda faz parte do domínio da família [Tupí-]Mondé (Aruá, Cinta-Larga, Gavião, Mondé, Zoró e Paitér), com destaque para a subfamília Paitér (Suruí), cuja cerâmica em nada lembra a Prototupí e a Tupíguaraní. O tronco Tupí tem seguramente no mínimo 5.000 a.P. segundo nossos estudos arqueológicos na região e datações de ${ }^{14} \mathrm{C}$, assim como segundo o estudo de Rodrigues publicado já em 1958, que é o autor que realmente estabeleceu a origem do tronco Tupí e sua posição geográfica.

(P.I.S.) "Nem cultivos nem cerâmica pertenciam então [i. é, 5.000 a.P.] ao seu patrimônio Cultural.” (p. 301).

(E.Th.M.) Se as datas ${ }^{14} \mathrm{C}$ mais antigas são válidas, os resultados arqueológicos, a terra preta, e tanto o cultivo como a cerâmica contam com um mínimo de 5.070 a.P. na Área Alto-Jiparaná, no alto rio Ji-Paraná, ocupado até 1915 A.D. pelos falantes da família Tupí-Guaraní, subfamília Kawahíb, sendo arqueologicamente a tradição Prototupí, em ambas as margens (Rondon 2003).

(P.I.S.) "Ao longo dos 2.000 anos seguintes [i. é, 5.000-3.000 a.P.] durante os quais a população cresceu e se expandiu (...) até o alto Xingu, no leste, a protolíngua Tupí se teria diversificado, dando origem às famílias do tronco Tupí hoje conhecidas." (p. 301).

(E.Th.M.) Segundo os resultados arqueológicos essa diversificação, que originou as famílias linguísticas, seguida pelas separações, já tinha sido iniciada por volta de 5.000 a.P., permanecendo seis famílias na região de Rondônia, o que está a indicar que a diversificação das famílias do tronco Tupí deve ter começado antes de qualquer migração para leste ou sueste. 
(P.I.S.) "Nesse tempo [i. é, os 2.000 seguintes: 5.000-3.000] devem ter chegado os primeiros cultivos e provavelmente os conhecimentos da fabricação da cerâmica" (p. 301).

(E.Th.M.) Como comunicado acima e segundo os resultados arqueológicos, se válidas, a terra preta e a datação ${ }^{14} \mathrm{C}$, tanto o cultivo como a cerâmica contam com um mínimo de 5.000 a.P. na Área Alto-Jiparaná.

(P.I.S.) "Ao redor do tempo de Cristo começariam migrações maiores, principalmente dos ascendentes da família conhecida como Tupí-Guaraní."

(E.Th.M.) Se a agricultura já era praticada aos 5.000 a.P., segundo a terra preta, dentro do Optimum Climático, a pressão populacional e grandes migrações já estariam acontecendo desde ca. 4.600 a.P., seguidas de outras dispersões forçadas pela semi-aridez, conforme fig. 29, coluna 4. A família diretamente atestada foi a Tupí-Guaraní através da subfamília Kawahíb ou Tupíkawahíb arqueológico.

(P.I.S.) "Nesse tempo [i. é, tempo de Cristo] deve ter-se fixado o primeiro grupo Tupí-Guaraní (...) ao longo do Alto Paraná e do Alto Uruguai (...) sul do Brasil (...) Paraguai (...) nordeste da Argentina.”

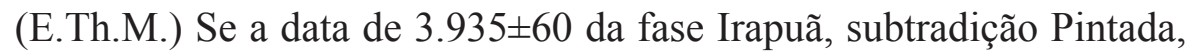
do Alto Uruguai, noroeste do Rio Grande do Sul (sudeste de Misiones, Argentina) for válida, então as migrações para o sul teriam sido iniciadas ao redor de 4.600, como aventado acima (fig. 29, coluna 4).

\section{Discussões e Conclusões}

Nossa proposição de contribuir com um trabalho sobre "A Cultura Cerâmica do Tronco Tupí no Alto-Jiparaná - Rondônia, Brasil, com algumas reflexões teóricas, hipotéticas e conclusivas" é resultado de uma série de pistas que tivemos sobre o assunto. A primeira grande pista ocorreu em 1950, lendo sobre a Comissão Rondon (Rondon e Faria 1948, Roquette-Pinto 1950). A segunda grande pista, li em 1966, a hipótese do emérito linguista Aryon Dall'Igna Rodrigues (1964) sobre a "terra natal" do Proto-Tupí, com ênfase em Rondônia. Nas roças que margeiam o rio Itapuí ou Sinos, RS, o que mais nos chamava a atenção eram as cerâmicas corrugada, pintada e escovada; todo colono tinha uma 'pedra de raio' para escorar a porta ou amolar a faca, 'cachimbo de barro' ou 'pedra de beiço', ou 'panela de índio ou bugre', etc. O índio Guaraní dos toldos, deculturado, exclamava rindo: "são dos Jesuítas". Durante o PRONAPA devo ter analisado cerca de meio milhão de fragmentos 
que terminaram sendo chamados de Tupíguaraní, de 1968 em diante. Durante esse tempo, de 1965 a 1973, ficamos pensando sobre como seria a cerâmica dos falantes Tupí-Guaraní na "terra natal" de Rodrigues; para nós a mais lógica dentre tantas propostas. Com o PROPA conhecemos os dois primeiros sítios com cerâmica corrugada do sudoeste da Amazônia, um no noroeste de Mato Grosso, próximo ao Abrigo do Sol, e o outro próximo ao Marco Rondon, junto ao igarapé Melgacinho, RO, afluente do baixo Comemoração, um dos formadores do rio Jíparaná, onde estivera a Comissão Rondon. Como fragmentos, vimos que o corrugado, raro, se encaixava dentro da variedade do tipo. O pintado, mais raro ainda, era sobre superfície raramente engobada sobre vermelho ou branco; era bem mais simples que os da Faixa Costeira e todos muito intemperizados pelo clima amazônico.

Por falta de pesquisas de campo para a grande maioria das hipóteses sobre o local de origem dos Tupí, pelos seus autores e simpatizantes, estas ficaram apenas sendo distribuídas centrífuga e centripetamente, no tempo e no espaço, desde que foram elaboradas; para o conhecedor da posição da cerâmica Proto-Tupíguaraní, umas ao acaso, chegaram mais perto que outras, mas faltaram as pesquisas de campo. Com uma exceção: esse feito, exemplo admirável, diz respeito à pessoa de Aryon Dall'Igna Rodrigues, como pesquisador de campo e laboratório, a quem a avançada idade não é visível, sentida e nem impecilho.

Em nossa pesquisa arqueológica, os relatos da Comissão Rondon e a hipótese de Rodrigues acertadamente nos nortearam e centripetamente nos conduziram ao esperado resultado arqueológico. Ou seja, à "terra natal" do Tronco-Tupí e ao centro de sua origem, desenvolvimento e difusão da cultura material da família linguística Tupí-Guaraní, constituído pela Área Alto-Jiparaná, em Rondônia. A linguística diacrônica de Rodrigues atribui ao menos 5.000 anos a.P. para o início do troncoTupí e 3.000-2.500 para a família Tupí-Guaraní. Desde 2001, as datações ${ }^{14} \mathrm{C}$ da tradição Prototupí estão

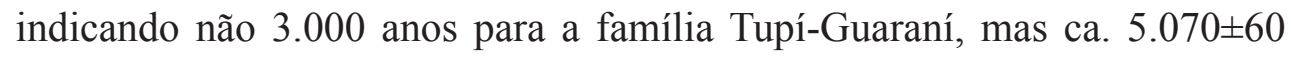
anos a.P.

Com esses primeiros resultados arqueológicos, de 1974 em diante, e essas datações ${ }^{14} \mathrm{C}$, de 2001 em diante, a hipótese de Aryon Dall'Igna Rodrigues tem confirmada e datada a posição geográfica do Tronco Tupí na mesopotâmia entre o Guaporé-Madeira e o Aripuanã, entre o Guaporé e o rio Ji-Paraná, mais especificamente ao longo da "Área Alto-Jiparaná", para o Proto Tupí-Guaraní, a mesma área da tradição Proto-Tupíguaraní 
arqueológica. Assim, a hipótese de Rodrigues (1958a, 1964, 1986), (salvo a estimativa de 3.000-2.500 anos para a família Tupí-Guaraní, que pelo ${ }^{14} \mathrm{C}$ arqueológico seria de ca. 5.070 \pm 60 a.P.) passa a ser um fato, confirmado pela nossa arqueologia de campo. Essa é a recompensa ao árduo trabalho do linguista de campo e laboratório, ao qual ele ainda se dedica com afinco.

Detalhando: com o PROPA, o PRONAPABA e alguns outros projetos de levantamento e resgate arqueológico até o presente, fomos centripetamente reduzindo o noroeste da Amazônia à "terra natal" de Rodrigues, à mesopotâmia Guaporé-Madeira e Aripuanã. Apertando o cerco sobre essa região mesopotâmica, fomos chegando a mais sítios-habitação e cemitérios com evidências arqueológicas cerâmicas de traços tipo Tupíguaraní, como a cerâmica corrugada e/ou pintada, consistentes e relevantes para a correlação em vista, envolvendo 52 sítios até 1986. A demarcação desse espaço, delimitado por evidências corrugadas e/ou pintadas, ficou sendo: ao Norte, na Lat. S. $7^{\circ}$ 57' 20”' e Long. W. 62 ${ }^{\circ}$ 03', margem esquerda do rio Marmelos com a BR-230/ AM; ao Sul, na Lat. S. $12^{\circ} 36^{\prime}$ e Long.W. 60 53', ca. igarapé Melgacinho, margem esquerda, com a BR-364 (Marco Rondon); a Oeste, junto à BR-429,

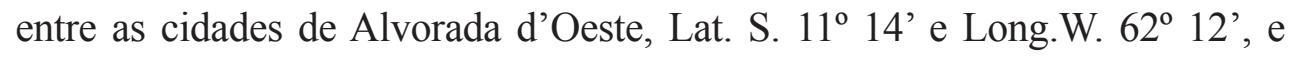
Presidente Médici; a Leste, junto à divisa dos estados de Rondônia e Mato Grosso, nascentes do córrego Molim, Lat. S. 10 59' e Long.W. 61 33', com o rio Branco, afluente do alto Roosevelt. Novo aperto levou à maior concentração de sítios da atual pesquisa de campo, ao longo do alto rio Ji-Paraná e afluentes, da Cachoeira do Arregaço até os baixos Comemoração (junto ao Marco Rondon, onde estivemos em 1975) e Pimenta Bueno.

Pelas correlações entre as posições geográficas, evidências linguísticas, evidências etno-históricas, com as evidências arqueológicas apoiadas pelas datações $14 \mathrm{C}$, concluímos que chegamos à tradição Prototupí. Noutras palavras: depois de 33 anos de Amazônia, grosso modo, esta é nossa contribuição. Afinal, entre si, não são tão diferentes assim estas evidências. Dá até para confundi-las. Compare-se a cerâmica corrugada do Rio Grande do Sul com a corrugada de Rondônia (figs. 7-15). O pintado é que é muito mais desenvolvido no litoral (figs. 4-6). Afinal, não são irmãs nem clones, mas sim a ascendente Prototupí com ao menos ca. 5.070 \pm 60 anos a.P., com origem na pequena Área Alto-Jiparaná, e o descendente Tupíguaraní na imensa Faixa Costeira, com diversidade ambiental latitudinal muito maior, e separadas por um longo espaço-tempo, com milhares de anos e quilômetros. Elas também são conhecidas na literatura como Guaraní (ramo I da família Tupí-Guaraní, tronco Tupí) do Sul-Sudeste e Tupínambá (ramo III da família Tupí-Guaraní, tronco Tupí) do Sudeste-Norte. 
Se a amostragem da cerâmica pintada, aqui apresentada, sugere que ela seja dos primórdios, como é, muito simples e pouco evoluída para 5.070 \pm 60 de existência, os líticos, pelo contrário, apresentam evidências de lâminas de machado bastante diferenciadas (fig. 17) e mais evoluídas (fig. 16) que na Faixa Costeira; o mesmo pode-se dizer de alguns tembetás em quartzo, mais delicados e frágeis.

Esses $5.070 \pm 60$ anos a.P da tradição Proto-Tupíguaraní e demais tradições Tupí e não-Tupí sofreram de escassez de toda ordem pelas consequências dos impactos climáticos de semi-aridez, e dispersões à procura da sobrevivência, que, no máximo, só uma minoria teria conseguido. Pela extensão e amplitude do fenômeno, teria ocorrido uma significativa regressão cultural e readaptação à pouca água, caça e coleta que teria sobrevivido. Ecologicamente, estavam instabilizados e falidos como agricultores e desestruturados como sociedade. A continuidade de uma evolução a caminho, ao menos duas vezes foi truncada e regrediu (fig. 29, coluna 4, $2^{\mathrm{a}}$ e $4^{\mathrm{a}}$ fases), e ao menos três vezes teria se recuperado (fig. 29 , coluna $4,1^{\text {a }}, 3^{\text {a }}$ e $5^{\text {a }}$ fases). A arqueologia ainda está longe de poder avaliar e esclarecer, pelas evidências materiais, o desenrolar dessa proto-história pré-histórica acerca da tradição Proto-Tupíguaraní (Miller, 1992a, b, 1999). Em Rondon (2003) encontramos os apontamentos sobre as condições de vida em que foram contatados não só os Kawahíb (da família Tupí-Guaraní), em 1909 a 1915 A.D., mas também os de outras famílias como os Kepkiriwát (da família Tuparí), os Arikém (da família Arikém), além de outros não-Tupí.

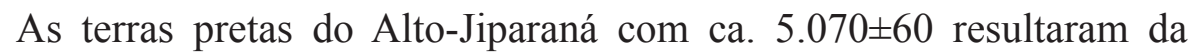
agricultura que gerou os aldeamentos semi-sedentários relacionados aos Proto-Tupíguaraní, quase tão antigos, como os da cultura Massangana que,

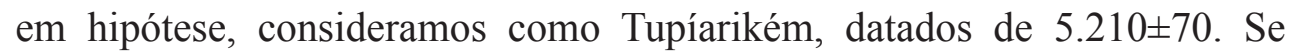
válido o Tupíarikém, fica sugerida a ampliação e regionalização de um centro de desenvolvimento da agricultura incipiente iniciada antes de 5.210 a.P., hipoteticamente durante o início e meio do Optimum Climático, entre 7.000 e 5.210 a.P., gerando diversidades sociais entre macro-bandos desde o PréPrototupí (fig. 29 , coluna $4,1^{\circ}$ e $2^{\circ}$ estágios), que resultaram nas primeiras separações (Meggers e Evans 1973).

Rodrigues observa que, como os Arikém ainda não teriam cerâmica há 5.210 anos, embora já tivessem agricultura, e embora sua palavra para 'roça' em Karitiána pareça herdada do Proto-Tupí, o que não se dá com as palavras para 'mandioca', 'batata doce' e 'cará', as quais as outras família do tronco Tupí 
têm em comum, fica a impressão de que, naquela época, eles seriam um povo que falava uma língua não-Tupí, mas que, mais tarde, teria mudado de idioma, possivelmente pela introdução de grande proporção de mulheres falantes de uma língua Tupí. Rodrigues observa também que a palavra Karitiána para 'marido' é nitidamente Tupí, mas o termo para 'esposa' não é Tupí. É possível que um exame mais extensivo do léxico Karitiána (infelizmente ainda não temos um dicionário mais amplo dessa língua) venha a revelar mais indicações em favor de uma mudança de língua com aquisição de um idioma Tupí carreado por mulheres incorporadas em certo momento da história a uma comunidade de homens não-Tupí (Rodrigues, com. pessoal, 2009).

O processo que culminou com a adoção do termo Tupíguaraní para a tradição cultural material dos falantes Tupí-Guaraní da Faixa Costeira (Brochado et al. 1969) e sua definição terminológica (Chmyz 1969, 1976), foi aplicado para a atribuição do termo Proto-Tupíguaraní à cultura material no alto Jíparaná dos derradeiros Tupí-Guaraní, os Kawahíb, e seus ascendentes de há ca. 5.070 \pm 60 a.P. Sua língua e registros etno-históricos revestem-se de grande interesse e importância para legitimar este trabalho. Ele visa a deixar patente que a tradição Proto-Tupíguaraní é um fato; que seu centro de origem está na Área Alto-Jiparaná, RO; que a origem da cultura material da tradição Tupíguaraní está nas expansões e migrações da tradição Proto-Tupíguaraní, para o que dificilmente as dispersões da semi-aridez teriam contribuído; que, hipoteticamente, seu progenitor é o caçador-coletor pré-ceramista e provável pioneiro da agricultura incipiente, integrante da então "terra natal arcaica", entre ca. 7.000 e 5.000 anos a.P. (fig. 29, coluna 4).

As correlações entre as posições geográficas, as evidências linguísticas Tupí-Arikém e as evidências etno-históricas, indicam que estamos no caminho certo para a tradição Tupíarikém. Contudo, a base nas evidências arqueológicas da tradição Jamarí (Miller et al. 1992) deve ser estendida sobre o alto Jamarí e pelo rio Candeias, com datações ${ }^{14} \mathrm{C}$. Então poderemos comprovar que chegamos à Tradição Protoarikém.

Pelas correlações entre as posições geográficas, evidências linguísticas Tupí-Tuparí, evidências etno-históricas e algumas evidências arqueológicas, conclui-se que estamos no caminho certo para, com mais arqueologia de campo e datações ${ }^{14} \mathrm{C}$, comprovarmos e chegarmos à Tradição Tupítupari.

Nossa impressão atual quanto às possíveis tradições culturais da terra natal ora em reconhecimento mediante as datações de ${ }^{14} \mathrm{C}$, levando em consideração dois extremos conhecidos, para o $3^{\circ}$ estágio cultural dos: 


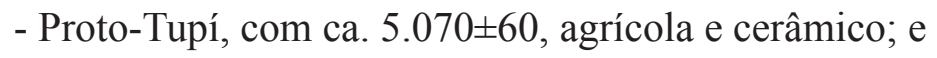

- Tupíarikém, com agricultura desde $5210 \pm 70$ a.P., mas cerâmica da tradição Jamarí só depois de ca. $2.500 \pm 90$ a.P. e A.D. 1.720, é de que entre as dez famílias Proto-Tupí houve uma diferenciação gradativa iniciada pela família Tupí-Guaraní ou Proto-Tupíguaraní arqueológico, desde o final do $2^{\circ}$ estágio estendendo-se até meados do $3^{\circ}$ estágio, mas podendo também ter sido um outro caminho semelhante a este o da diferenciação linguística das famílias do Tronco Tupí (fig. 29, colunas 4 e 6).

Digna de menção é a proximidade dos centros das duas tradições culturais com os tipos pintados mais antigos na Amazônia - a Tradição Polícroma Subtradição Jatuarana na Cachoeira do Teotônio, no rio Madeira até Guajará-Mirim no rio Mamoré, com ca. 3000 a.P. na primeira, e a Tradição

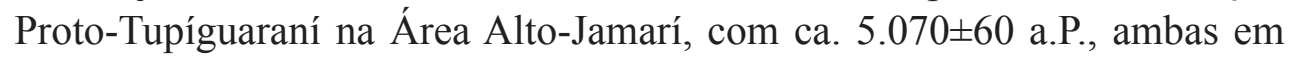
Rondônia no Sudoeste da Amazônia, com cerca de $300 \mathrm{~km}$ lineares entre ambas, no centro da imensidão amazônica.

Etnia, linguagem e cultura são variáveis independentes. Este critério foi observado na Faixa Costeira Brasileira pelo Pronapa, para testar a verificação de correlações seguras entre língua Tupí-Guaraní e cerâmica arqueológica, entre a coincidência de seus espaços de assentamento e suas cronologias, para a incontestável demonstração da existência da tradição Tupíguaraní (arqueológica). Este mesmo critério foi aplicado na "terra natal" do Tronco Tupí, até o presente, com o mesmo resultado: foi testado e constatado por nós que existe uma segura correlação entre a presença de uma língua Tupí-Guaraní (Kawahíb) e a cerâmica arqueológica, constituída por evidências de cerâmica corrugada e pintada, assim como entre a coincidência de seus espaços de assentamento e suas cronologias, para a incontestável demonstração da existência da tradição Proto-Tupíguaraní (ou como vier a ser denominada). Foi reconhecida ainda entre os índios Kawahíb, entre 1909 e 1915, por pesquisadores acompanhantes e colaboradores da Missão Rondon, como João Barbosa Faria, etnógrafo (este, originalmente estudante de direito) e Edgar Roquette-Pinto, antropólogo, assim como em 1938 pelo etnólogo Claude Lévi-Strauss. E desde 1958, por Aryon Dall'Igna Rodrigues, linguista de campo e laboratório, hoje na Universidade de Brasília, que classificou o tronco Tupí e suas dez famílias. Com a reconstrução de palavras, principalmente as de conotação direta e indireta com a cultura material, ele está auxiliando a arqueologia a interpretar muitas evidências, que, se não fosse isso, estariam prejudicadas ou perdidas para sempre. 
Para encerrar, a questão tempo, ambiente, influência e consequência: até o final do oitavo milênio a.P. no sudoeste da Amazônia os caçadores-coletores compunham três tradições culturais maiores, duas em extinção, que utilizavam artefatos de pedra lascada, uma delas também com pontas de projétil de pedra lascada (Meggers e Miller 2003), e uma terceira tradição em evolução com lascas simples de pedra para a confecção de utilitários de expediente em madeira, osso, etc. Esses são os ascendentes e precursores das culturas de floresta do sétimo milênio (com dois relictos vivos, os Mura-Pirahã dos rios e lagos e os Nambikwára da mata e do cerrado). Serão os bandos e macrobandos de caçadores-coletores direta e indiretamente os ascendentes dos que viriam a ser os futuros Tupí? Como estariam distribuídos nos tempos dos $1^{\circ} \mathrm{e} 2^{\circ}$ episódios, entre 7.000 e 5.000 anos a.P. na mesopotâmia do Guaporé-Madeira e Aripuanã, então a "terra natal arcaica"? O panorama ao sul da região continha a Depressão do Guaporé, semi-árida, 150 m.a.n.m.m., e a Chapada dos Parecis, 650 m.a.n.m.m., com chuvas escassas, hipoteticamente cerca da "metade" das chuvas atuais, o suficiente para um emaranhado de nascentes, alimentadas pelo aquífero do Chapadão dos Parecis, suportar irregularmente matas de galeria de entremeio a matas abertas sobre litossolos, com urucurizais que se estendiam até o meio da região, até o encontro com a Formação Barreiras, ácida e pobre em nutrientes, onde a vegetação alimenta-se de si mesma, e que se estende quase plana até o rio Amazonas, coberta de savanas ou cerrados e matas de galeria abertas. Nesse bioma de quase só savana ou cerrado, mais abundante de caça, os bandos e macro-bandos de caçadores-coletores se dispersaram e evoluíram ao máximo possível. Encontrava-se saturado de afloramentos areníticos e graníticos, nos declives mergulhando no sentido do Rio Amazonas, 90 m.a.n.m.m. Essa composição florística e respectiva fauna se estenderiam até muito além dos limites da "terra natal arcaica". Nesse espaço de tempo estava ocorrendo o início e o auge do Optimum Climático, com muito calor, muita pluviosidade e umidade, hipoteticamente cerca do "dobro" de agora. As cheias dos rios alargaram os seus leitos e os sedimentos, hipoteticamente o dobro de agora, erigiram as várzeas só atingidas hoje nas grandes cheias. $\mathrm{O}$ rio Madeira soterrou igapós e planícies de inundação. O nível do mar em um milênio e meio chegaria de 3 a $5 \mathrm{~m}$ acima do atual, a maré atingiria até Manaus. A Depressão do Guaporé se transformou no Pantanal do Guaporé. As matas de galeria coalesceram, ocupando os espaços antes dos cerrados. As terras baixas do norte da região foram alagadas e encobertas pelas águas. O bioma dos cerrados foi sendo substituído pela floresta densa e contínua, com outra fauna, diversa e menos abundante, imprópria para o estilo de vida até então existente. 
Assim foram sendo traçados os limites da futura terra natal. Na alvorada do quinto milênio os Tupí que permaneceram na terra natal estavam concentrados na metade meridional, a mais alta e enxuta da região, principalmente em Rondônia, nas terras florestadas com urucurizais, próprias para a agricultura. Com o tempo, culturas indígenas se desfizeram como os cerrados, se formaram e se expandiram como a floresta coalescente, se deslocaram a procura das mesmas condições pretéritas. Com o fim do Optimum Climático, após uma drástica semi-aridez, ca 4.400 a 4.100 a.P., o clima assumiu as condições atuais, mas logo uma segunda semi-aridez se interpôs. Restabelecendo-se as condições climáticas anteriores, as regiões baixas alagadas, agora desalagando, deram lugar aos lagos atuais. As chuvas e a umidade normalmente são suficientes para a preservação das florestas com pequenos enclaves e relictos de campos sujos e cerrados, mais pela lixiviação e constituição do solo, encobrindo os grandes areais em meio às formações arbustivas com matas. Os Tupí certamente não foram os únicos que ocuparam, padeceram e se beneficiaram dessa região.

O cotejo e cruzamento entre: (1) as fontes linguísticas do tronco Tupí com alcance cronológico de ao menos o do Prototupí arqueológico da "terra natal"de Rodrigues (1958a); (2) as fontes etnográficas/etnológicas da Comissão Rondon (1909-1915), de Lévi-Strauss (1938), de Caspar (1948 e 1955) e outros, com extensão cronológica que deverá ultrapassar o presente; e (3) a arqueologia de Miller com participações de Angelo Ravani e Rosicler da Silva (Miller et al. 1992, Miller 1987b, c) revelou os primeiros resultados surpreendentemente antigos e diversificados, quanto à cultura material, representada principalmente pelas cerâmicas corrugada e pintada do Proto-Tupíguarani arqueológico, na mesopotâmia Guaporé-Madeira e Aripuanã, com ca. 5.210 70 .

Ao redor do ano de 2005, um reforço considerável começa a impulsionar as pesquisas arqueológicas nessa região, através de empresas como a Scientia S. A. e outras, contando com arqueólogos de renome associados, contratados ou independentes, como Eduardo G. Neves, Renato Kipnis, Daniel Flores, Carlos Zimpel Neto e muitos outros.

Contudo, aqueles que confeccionaram todo esse patrimônio cultural material e imaterial - desde que os não-indígenas entraram em contato com os nativos - foram morrendo como povos ou pessoas independentes, como autores e atores, como falantes e ouvintes, como representantes de etnias autóctones, devido às diversas epidemias trazidas de fora. Uns morreram, outros se submeteram à escravidão, foram assimilados ou se deslocaram e se integraram a outros grupos indígenas. Assim, cartograficamente, hoje, 
os povos remanescentes dos Kawahíb se localizam fora do vale do alto JiParaná, ou seja, no vale do Guaporé em Rondônia e no sudoeste do Amazonas, afastados do rio Madeira.

Consequentemente, como disse Lévi-Strauss

(...) se nossos indígenas estivessem de fato decididos (como eu começava a desconfiar, e verifiquei em seguida) a deixar definitivamente sua aldeia para aderir à civilização (...) toda a história da colonização na América do Sul e em outras partes deve levar em conta essas radicais renúncias, essas desagregações de um gênero de vida em que a perda de certos elementos acarreta a depreciação imediata de todos os outros, fenômeno do qual eu talvez acabasse de observar um típico exemplo (Lévi-Strauss [1955]2005:326).

\section{Recomendações}

Nesses últimos 33 anos de campo naAmazônia, presenciamos e vivemos, impotentes, situações dramáticas, mais sobre o patrimônio arqueológico do que sobre nós mesmos, na calha do rio Madeira. Grande parte do que não foi totalmente destruído agora ficará impossibilitado de ser pesquisado devido aos reservatórios das hidrelétricas.

Nesse mesmo período, a floresta que cobria o sul de Rondônia foi substituída pelo novo El Dorado agropastoril em que o sudoeste da Amazônia foi sendo transformado. A questão Tupí especificamente, antes de ser equacionada, já estava sendo bastante prejudicada, muito mais rapidamente do que na Faixa Costeira. Nesse tempo, trabalhávamos a sós, independentemente, essa questão, os temas de campo arqueológicos (E. Th. Miller) e os linguísticos (A. D. Rodrigues). O estudo do Tupí estava ficando cada vez mais complexo. Já com as primeiras datações, ambas as disciplinas tiveram seus resultados, queiramos ou não, empurrados, esticados para o passado, causando rompimentos e remendos e reformas em hipóteses e conceitos.

Com um maior volume de empreendimentos ocorrendo, outros arqueólogos serão iniciados na arqueologia desta porção amazônica e, se não houver uma intercomunicação prévia para nivelar os procedimentos, resultará uma confusão babilônica. Tudo o que envolve a reconstituição da história e da pré-história humana e ambiental deve "compor e vestir" um grande grupo interdisciplinar de pesquisadores como se fosse uma pessoa só, para se entenderem, o que é fundamental. E não há outra saída sob pena de o resultado final ser mais uma 
história babilônica. Além dos arqueólogos se afinarem reciprocamente, eles não prescindem da linguística, como esta não poderá prescindir do ${ }^{14} \mathrm{C}$ da arqueologia. Noutras palavras, faz-se necessária daqui por diante uma série de seminários anuais para dirimir dúvidas sobre metodologia, terminologia, linguística Tupí, etc. Na Faixa Costeira eram só línguas da família Tupí-Guaraní, mas na "terra natal" e fora dela foram dez famílias linguísticas. Então, vale a pena incluirmos linguistas e arqueólogos e outros especialistas nos nossos seminários.

Recomendamos orientarem, de início, as pesquisa de sítios e cortesexperimentais às áreas junto às cachoeiras, corredeiras e baixios dos rios, que nas estiagens propiciavam grandes pescarias pré-históricas. Aí estão os sítios principais e, se houver terras pretas pré-cerâmicas de agricultores ProtoTupíguaraní, Tupítuparí e Tupímondé, etc., estas estarão por debaixo das camadas de terra preta com cerâmica, de imediato ou após camadas de solo estéril. Portanto, várias sondagens até 2-3 metros de profundidade são fundamentais. E, como a percussão destrói as evidências, recomendamos o trado, que funciona por pressão, a qual pode ser controlada e reduzir os danos.

Como em média a espessura da camada arqueológica Proto-Tupíguaraní está ao redor de $50 \mathrm{~cm}$, podendo ter até ca. 5.000 anos a.P. - uma média de um século para cada centímetro, ou um milênio para cada $10 \mathrm{~cm}-$, recomendamos efetuarem a decapagem em camadas de $5 \mathrm{em} 5 \mathrm{~cm}$, em ao menos um corte experimental por sítio, se possível de $2 \times 2 \mathrm{~m}$, porque quanto maior e mais detalhada for a amostra, maior é a representatividade dos tipos (lato sensu), o que reduz as dúvidas. Quanto mais cortes melhor, pois o indígena, como nós, pode ser bastante imprevisível: não conhecemos duas aldeias absolutamente idênticas, sempre há o imprevisível atuando, mais cedo ou mais tarde, tanto agora como no passado.

\section{Referências}

Abreu, J. C. de. 1963. A bandeira de Francisco de Mello Palheta ao Madeira e o documento de narração da viagem. In: Capítulos de História Colonial (15001800) \& Os caminhos antigos e o povoamento do Brasil. $5^{\text {a }}$. ed., Brasília: Ed. Univ. de Brasília. 402 p.

Albanese, John P. 1977. Geologic reconnaissance of the Abrigo do Sol Rockshelter, Matto Grosso, Brazil. (Ms.). Research Associate, Smithsonian Institution. Casper, Wyoming.

Almeida Serra, R. F. de. 1866. Extrato da descrição geographica da provincia de Matto Grosso feita em 1797, por Ricardo Franco de Almeida Serra, 
sargento-mor de engenheiros. Rev. Inst. Hist. Geogr. Bras., 2a ${ }^{\text {a }}$ ed., 6:156-96. Rio de Janeiro.

Almeida Serra, R. F. de, et al. 1857. Roteiro chorographico da viagem que se costuma fazer do forte Principe da Beira a Villa Bella, capital do Mato Grosso. Extrahido do diario astronomico (...) 1781, (...). 1857. Rev. Inst. Hist. Geogr. Bras. 20:390-96. Rio de Janeiro.

Bailey, Robert., et al. 1989. Hunting and gathering in the tropical rainforest: is it possible? American Anthropologist 91:59-82.

Brochado, José P., et al. 1969. Arqueologia brasileira em 1968. Publicações Avulsas do Museu Paraense Emílio Goeldi, 12. Belém.

Chmyz, Igor (org.). 1966. Terminologia arqueológica brasileira para a cerâmica. Parte I. Manuais de Arqueologia, $\mathrm{n}^{\circ} 1$. Centro de Estudos e Pesquisas Arqueológicas. Curitiba.

Chmyz, Igor. 1969. Terminologia arqueológica brasileira para a cerâmica. Parte II. Manuais de Arqueologia, $\mathrm{n}^{\circ}$ 2. Centro de Estudos e Pesquisas Arqueológicas. Curitiba.

Chmyz, Igor. 1976. Terminologia arqueológica brasileira para a cerâmica (revista e ampliada). Cadernos de Arqueologia, 1:119-148. Curitiba.

Cruz, Daniel G. da. 2008. "Lar, Doce Lar? Arqueologia Tupí na Bacia do JiParaná (RO)”. Dissertação de Mestrado em Arqueologia. MAE/USP, São Paulo.

Dyen, Isidore. 1956. Language distribution and migration theory. Language, 32:611-626.

Fonseca, J. Severiano da. 1880. Viagem ao redor do Brasil, 1875-78. 2 vols. Rio de Janeiro.

Headland, T. N. 1987. The wild yam question: how well could independent hunter-gatherers live in a tropical rainforest environment? Human Ecology, 15:463-91.

Leite, S. 1945. História da Companhia de Jesus no Brasil, vol. 6. Rio de Janeiro: Inst. Nacional do Livro.

Lévi-Strauss, Claude. [1955] 1996. Tristes trópicos. Trad. Rosa Freire d'Aguiar, São Paulo, Companhia das Letras.

Lévi-Strauss, Claude. [1955] 2005. Tristes trópicos. Trad. de Rosa Freira d'Aguiar. São Paulo: Companhia das Letras.

Lévi-Strauss, Claude. [1994] 2001. Saudades do Brasil. Trad. de Paulo Neves. $2^{\mathrm{a}}$ reimpressão. São Paulo: Companhia das Letras.

Magalhães, Amilcar A. B. 1941. Pelos sertões do Brasil. (Brasiliana, vol. 195), $2^{\mathrm{a}}$. ed. São Paulo: Companhia Editora Nacional. 
Meggers, Betty J.; Clifford Evans. 1973. A reconstituição da pré-história amazônica (algumas considerações teóricas). Publ. Avul. Mus. Paraense Emílio Goeldi, 20:51-69.

Meggers, Betty J.; Eurico Th. Miller. 2003. Hunter-gatherers in Amazonia during the pleistocene-holocene transition. In: J. Mercader (org.), Under the canopy: the archaeology of tropical rain forests, 291-316. New Brunswick, New Jersey e Londres: Rutgers University Press.

Menéndez, Miguel A. 1992. A área Madeira-Tapajós: situação de contato e relações entre colonizador e indígenas. In Manuela C. da Cunha (org.), História dos índios do Brasil, 281-296. São Paulo: Companhia das Letras/ FAPESP.

Migliazza, Ernest C. 1982. Linguistic prehistory and the refuge model in Amazonia. In: Ghilean T. Prance (org.). Biological diversification in the tropics, 497-519. New York: Columbia University Press.

Miller, Eurico Th. 1961. Pesquisas arqueológicas em campo aberto.

Apresentado nos II Encontros de Intelectuais de São Paulo, São Paulo, 21-26 de agosto de 1961 (ms.).

Miller, Eurico Th. 1969a. Pesquisas arqueológicas efetuadas no noroeste do Rio Grande do Sul (Alto Uruguai). In: Programa Nacional de Pesquisas Arqueológicas, 2: resultados preliminares do segundo ano, 1966-7. Publicações Avulsas do Museu Paraense Emílio Goeldi, 10:33-46. Belém.

Miller, Eurico Th. 1969b. Pesquisas arqueológicas efetuadas no oeste do Rio Grande do Sul (Campanha - Missões), rios Uruguai, Ibicuí e Quaraí. In: Programa Nacional de Pesquisas Arqueológicas, 3: resultados preliminares do terceiro ano, 1967-1968. Publicações Avulsas do Museu Paraense Emílio Goeldi, 13:13-30.

Miller, Eurico Th. 1969c. Resultados preliminares das escavações no sítio pré-cerâmico RS-LN-1: Cerrito Dalpiaz (abrigo-sob-rocha), rio Maquiné. Iheringia, Série. Antropologia 1:43-112. Porto Alegre: Museu Riograndense de Ciências Naturais.

Miller, Eurico Th. 1974-75. Pesquisas arqueológicas no sítio MT-GU-01: Abrigo do Sol (e região circundante), Mato Grosso e Rondônia, Brasil, 1974/75. Relatório preliminar. Programa Paleoindio-PROPA/SI-MARSUL. 10 p. mapa.

Miller, Eurico Th. 1977. Pesquisas arqueológicas no Sítio MT-GU-01: Abrigo do Sol (e região circundante), Mato Grosso, Brasil. Relatório preliminar. Programa Paleoindio-PROPA/SI-MARSUL. 11 p. mapa.

Miller, Eurico Th. 1979. Relatório das pesquisas arqueológicas realizadas no sudoeste do Estado do Amazonas - Médio rio Madeira. Resultados 
preliminares, 1979. Programa Nacional de Pesquisas Arqueológicas na Bacia Amazônica-PRONAPABA. 1979. 10 p. mapa.

Miller, Eurico Th. 1980. Pesquisas Arqueológicas no Território Federal de Rondônia. Resultados preliminares. Programa Nacional de Pesquisas Arqueológicas na Bacia Amazônia. ALBANESE-PRONAPABA/SIMARSUL. 19/08-14/11/1980. 22 p. Mapa.

Miller, Eurico Th. 1982. Relatório preliminar das pesquisas arqueológicas realizadas nas áreas de Pesquisa de campo de nos. 9 a 12, de 1974 a 1980 nos Estados do Amazonas, Mato Grosso e Rondônia. Resultados preliminares. Programa Nacional de Pesquisas Arqueológicas na Bacia Amazônica-Pronapaba/SI-GERO. 08 p.

Miller, Eurico Th. 1983a. Relatório preliminar das pesquisas arqueológicas realizadas nos Estados do Amazonas, Mato Grosso e Rondônia. Resultados preliminares. Programa Nacional de Pesquisas Arqueológicas na Bacia Amazônica-PRONAPABA/SI-GERO. 1983a. 18 p. Mapa.

Miller, Eurico Th. 1983b. História da cultura indígena do alto Médio-Guaporé (Rondônia e Mato Grosso). Dissertação de Mestrado em História da Cultura Brasileira, Pontifícia Universidade Católica do Rio Grande do Sul.

Miller, Eurico Th. 1986. A ocupação humana pré-histórica do Pantanal do Guaporé. In: Anais, VEncontro de Pesquisadores da Amazônia. Manaus, Amazonas, 25 a 27 de junho de 1986.

Miller, Eurico Th. 1987a. Pesquisas arqueológicas paleoindígenas no Brasil Ocidental. In: L. Nuñez \& B. J. Meggers (orgs.), Investigaciones paleoindias al sur de la línea ecuatorial, 1979. Estudios Atacameños 8:37-61.

Universidad del Norte, Inst. de Investigaciones Arqueológicas R. P. Gustavo le Paige. San Pedro de Atacama, Univ. del Norte.

Miller, Eurico Th. 1987b. Relatório do Programa de Estudos de Viabilidade Arqueológica nas áreas de inundação e de influência da U.H.E. Ji-Paraná 1986 - 1987. Consórcio Nacional de Engenheiros Consultores S.A.

Miller, Eurico Th. 1987c. Projeto de avaliação do potencial arqueológico na área de influência da rodovia BR-429-Presidente Médici - Costa Marques. Governo do Estado de Rondônia. Secretaria do Estado do Planejamento e Coordenação Geral-SEPLAN.

Miller, Eurico Th. 1987d. Inventário arqueológico da bacia e sub-bacias do Rio Madeira - 1974-1987. Consórcio Nacional de Engenheiros Construtores S.A.

Miller, Eurico Th. 1987e. Pesquisas arqueológicas no Território Federal de Rondônia. Relatório preliminar. Secretaria de Esportes e Turismo do Estado de Rondônia. 
Miller, Eurico Th. 1992a. Adaptação Agrícola Pré-Histórica no Alto Rio Madeira. In: B. J. Meggers (org.), Americans before Columbus: Prehistoric South Americans, 1988. Pp. 219-229. Washington, D.C.: Taraxacum.

Miller, Eurico Th. 1992b. A biofisionomia dos ecossistemas do sudoeste amazônico e os modelos de ocupação indígena pré-histórica: uma contribuição etno-arqueológica introdutória. Trabalho apresentado no Segundo Simpósio Internacional de Estudos Ambientais em Florestas Tropicais úmidas Forest'92. Rio de Janeiro, RJ, 24-29/05/1992. 15p. il. (inédito).

Miller, Eurico Th. 1995. Pesquisas arqueológicas no médio Uatumã - Urubu / AM. Eletronorte, 1995 - Smithsonian Institution. 57 p. il. (inédito).

Miller, Eurico Th. 1999. A limitação ambiental como barreira à transposição do período formativo indígena no Brasil; tecnologia, produção de alimentos e formação de aldeias no sudoeste da Amazônia. P. Ledergerber (org.), Formativo sudamericano: una reevaluación, 1992. Pp. 331-339. Quito: Ediciones Abya-Yala.

Miller, Eurico Th. 2009. Pesquisas arqueológicas no pantanal do Guaporé, RO, Brasil: a sequência seriada da cerâmica da Fase Bacabal. In: Betty Meggers (org.), Arqueologia interpretativa. O método quantitativo para etabelecimento de sequências cerâmicas: estudos de caso, p. 103-107. Porto Nacional: UNITINS.

Miller, Eurico Th. 2007. Sequências seriadas quantitativas aplicadas às culturas, cerâmica e pré-cerâmica arqueológicas, e interpretações de seus resultados sob efeitos do meio ambiente. In: I Seminário de Arqueologia de Sul Americanistas na Amazônia Ocidental. UNIR, 25 e 26/10/2007. (no prelo).

Miller, E. Th., et al. 1992. Arqueologia nos empreendimentos hidrelétricos da Eletronorte: resultados preliminares. Centrais Elétricas do Norte do Brasil S.A. Brasília-DF.

Mithen, Steven J. 2007. Depois do gelo: uma história humana global 20.0005.000 a.C. Rio de Janeiro: Imago.

Nimuendajú, Curt. 1981. Mapa etno-histórico de Curt Nimuendajú. Fundação Instituto Brasileiro de Geografia e Estatística e Fundação Nacional PróMemória. Rio de Janeiro: IBGE, 96 p., 1 mapa.

Ricardo, C. A.; F. Ricardo (orgs.), Povos indígenas no Brasil 2001-2005. São Paulo: Instituto Socioambiental.

Rodrigues, Aryon D. 1958a. Klassifikation des Tupí-Sprachstammes. In: Jens Yde (org.), Proceedings of the 32nd International Congress of Americanists, pp. 679-684. Copenhague: Munskgaard.

Rodrigues, Aryon D. 1958b. Classification of Tupí-Guaraní. International Journal of American Linguistics, 24:231-234. 
Rodrigues, Aryon D. 1964. A classificação linguística do tronco Tupí. Revista de Antropologia, 12:99-104.

Rodrigues, Aryon D. 1986. Linguas Brasileiras: para o conhecimento das línguas indigenas. São Paulo: Loyola.

Rodrigues, Aryon D. 1988. Proto-Tupí evidence for agriculture. Trabalho apresentado na 1st International Ethnobiology Conference. Belém.

Rodrigues, Aryon D. 1998. Tupí. In: R. W. M. Dixon \& Alexandra Y. Aikhenvald (orgs.), Amazonian Languages, pp. 107-124. Cambridge: Cambridge University Press.

Rodrigues, Aryon D. 2000. Hipóteses sobre as migrações dos três subconjuntos merdiionais da família Tupí-Guaraní. Anais do II Congresso Nacional da Associação Brasileira de Linguística. Florianópolis: CD-ROM.

Rodrigues, Aryon D. 2007. Tupí languages in Rondônia and in eastern Bolívia. In: W. Leo Wetzels (ed.). Language endangerment and endangered languages: linguistic and anthropological studies with special emphasis on the languages and cultures of the Andean-Amazonian border area. CNWS Publications. (ILLA) 5:335-363.

Rodrigues, Aryon D. 2010. Linguistic reconstruction of elements of prehistoric Tupí culture. A aparecer em livro comemorativo dos 60 anos de Willem Adelaar, Universidade de Leiden.

Rondon, Cândido M. S. [1916]2003. Missão Rondon, apontamentos sobre os trabalhos realizados pela Comissão de Linhas Telegráficas Estratégicas de Mato Grosso ao Amazonas, sob a direção do Coronel de Engenharia Cândido Mariano da Silva Rondon, de 1907 a 1915. (Nova edição) Brasília: Senado Federal, Conselho Editorial (Edições do Senado Federal, vol. 8).

Rondon, Cândido M. S.; João Barbosa de Faria. 1948. Glossário geral das tribos silvícolas de Mato-Grosso e outras da Amazônia e do norte do Brasil, tomo I. Comissão Rondon, publicação n. 76. Rio de Janeiro: Conselho Nacional de Proteção aos Índios.

Roosevelt, Ana C., et al. 1996. Paleoindian cave dwellers in the Amazon: the peopling of the Americas. Science, 272:373-384.

Roquette-Pinto, Edgar. 1917. Rondonia. Arquivos do Museu Nacional. Rio de Janeiro.

Roquette-Pinto, Edgar. 1950. Rondônia. $5^{\mathrm{a}}$ ed. Biblioteca Pedagógica Brasileira ( $5^{\mathrm{a}}$ Série Brasiliana, v. 39). São Paulo: Companhia Editora Nacional.

Schmitz, Pedro I. 1991. Migrantes da Amazônia: a tradição Tupíguaraní. In: Arno A. Kern (org.), Arqueologia pré-histórica do Rio Grande do Sul, 295-330. Porto Alegre: Mercado Aberto. 
Simões, Mario F.; F. Araujo-Costa. 1978. Áreas da Amazônia Legal Brasileira para pesquisa e cadastro de sítios arqueológicos. Publicações Avulsas, n. 30. Belém: Museu Paraense Emílio Goeldi,

Smithsonian Institution. 1992. New Program Coordinates Paleoindian Search. In: Smithsonian Institution Research Reports, Number 3, Winter 1972-1973. pp.1 and 3.

Southey, Robert. 1862. História do Brazil. Tomo quinto. Rio de Janeiro: Livraria de B. L. Garnier.

Suguio, Kenitiro. 1999. Geologia do quaternário e mudanças ambientais (passado+presente=futuro?). São Paulo: Paulo's Comunicação e Artes Gráficas.

Zimpel Neto, Carlos A. 2009. "Na direção das periferias extremas da Amazônia: arqueologia na bacia do rio Jiparana, Rondônia". Dissertação de Mestrado em Arqueologia. MAE/USP, São Paulo, 2009. 


\section{LEGENDAS (FOTOS AO FINAL DO TEXTO)}

Fig. 1 - O espaço sul-americano e amazônico: a porção sudoeste e a posição geográfica do tronco Tupí-Guaraní (Rodrigues, 1958a, 1964, 1986) na mesopotâmia GuaporéMadeira e Aripuanã; e do Proto-Tupíguaraní concentrado no Alto-Jiparaná. Ao lado, a sudoeste, o Pantanal do Guaporé com os sambaquis Sinimbu e Bacabal. Cerca de $300 \mathrm{~km}$ ao sul, o Abrigo do Sol e o sítio MT-GU-27: Tamanduá com terra preta e cerâmica Proto-Tupíguaraní, no Refúgio Guaporé. Para o sud-sudeste, distanciado de 1.500 a 3000 km, a Faixa Costeira e a concentração do Tupíguaraní. No Rio Grande do Sul a oeste sobre o rio Uruguai os paleoíndios Uruguai e Ibicuí; a leste o abrigo Cerrito Dalpiaz com a fase Umbu. A Corrente de Jato ou Jet Stream que flui de oeste para leste, transportou e precipitou cinzas vulcânicas chileno-argentinas sobre a biota, ca. 10.500 - 10.000, com completo restabelecimento ao redor de 9.500 a.P. (com vestígios no sul da África).

Fig. 2 - Na "terra natal". Em espaços no Médio Roosevelt, AM, no Alto-Jiparaná até os baixos Comemoração e Apediá, dentro da mesopotâmia Guaporé-Madeira e Aripuanã, onde desde 1974 vem sendo levantada a presença do Proto-Tupíguaraní com as cerâmicas corrugada e pintada, etc., antecessoras das similares ao sul-sudeste da Faixa Costeira, conforme a concentração do Tupíguaraní em 1969.

Fig. 3 -A. Tipos de clima (Köppen), desde o Refúgio Rondônia-Aripuanã coincidente com a "terra natal" do Proto-Tupí e tronco Tupí e a tradição Proto-Tupíguaraní (1); Am, Quente com curta estação seca; Aw, sobre o divisor Guaporé-Paraguai; (2), Quente com semestre de inverno seco; Cwa e Cwb, respectivamente a leste e oeste do Pantanal do Paraguai; (3), Tropical de altitude com semestre de inverno seco e verão quente (no Brasil), e verão brando (na Bolívia); Cfa e Cfb, respectivamente no extremo Sul da Faixa Costeira e na porção mediana do sul da Faixa Costeira; (4), subtropical com chuvas bem distribuídas com verão quente (RS) e com verão brando (SC, PR e SP) (adaptado de: HOUAISS 1981, BRASIL, CNG 1966, 1977b, c, d).

Fig. 3 - B. Tipos de vegetação. Mesmo espaço físico de A. (1) Fpa, Floresta perenifólia amazônica; Fsa, Floresta subcaducifólia amazônica; Fst, Floresta subcaducifólia tropical; Ct, Campo tropical; S, Savana; CP, Complexo do Pantanal; Fss, Floresta subcaducifólia subtropical; FSa, Floresta subcaducifólia subtropical com Araucaria angustifolia; Fpc, Floresta perenifólia costeira; SC, Savana do norte do Chaco; Pi, Pântano inundável; MxC Mata xerófila do Chaco; Cs, Campo subtropical e temperado; Fta, Floresta tropical andina; Eax, Estepe, arbustos xerófilos; Ea, Estepe árida (adaptado de: HOUAISS 1981, BRASIL, CNG 1966, 1977b, c, d)

Fig. 3 - C. Tradição Tupíguaraní da Faixa Costeira. Localização das fases e sítios arqueológicos das subtradições pintada e corrugada da tradição Tupíguaraní no 
sudoeste da Faixa Costeira. Distribuição das 10 famílias linguísticas do Tronco Tupí: (1) Puruborá, (2) Mondé, (3) Ramaráma, (4) Tuparí, (5) Arikém, (6) Jurúna, (7) Mundurukú, (8) Tupí-Guaraní, (9) Mawé e (10) Awetí (Rodrigues 1958a, b, 1964, 1986). O centro de dispersão ou "terra natal" (linha cheia), com o rio Ji-Paraná pelo meio, contém seis famílias, abrangendo a porção setentrional do Refúgio Guaporé e Refúgio Rondônia-Aripuanã, em RO e MT. As setas cheias representam dispersões anteriores a 2.000 anos a.P., e as tracejadas, posteriores (Meggers e Evans 1973). Datação arqueológica do NW argentino, de 2.700 anos a.P. (Meggers e Evans 1973). Miller admite que a tradição Proto-Tupíguaraní agrícola e cerâmica com ca. 5.000 anos a.P. para o Alto-Jiparaná, RO, sugere que a expansão e migração já teriam iniciado pelo menos há ca. 4.300 anos a.P., na transição da Fase 1 úmida para a Fase 2 semi-árida, com dispersões. Ou ainda antes, há ca. 4.500 anos por provável excesso de população, para o sul e sudeste, onde as condições poderiam não estar melhores (fig. 29, coluna 4; com projeção dos semi-áridos da coluna 1 Umbu-Itapuí, RS e coluna 5 Sinimbu-Bacabal, RO).

Figs. 4 e 5 - Decoração típica da tradição Proto-Tupíguaraní em Rondônia, AltoJiparaná: unicolor, branco ou preto sobre superfície simples, sem engobo; em cerca de $2-5 \%$ dos pintados ocorrem os pintados de vermelho sobre engobo branco e branco sobre engobo vermelho. São comuns os motivos de cestaria com linhas simples a triplas, com disposição quadrangular e losangular, próximas ou afastadas; com áreas preenchidas totalmente de branco ou preto, ou com linhas paralelas (achurado). $\mathrm{O}$ intemperismo químico plurimilenar em geral degradou progressivamente as amostras mais profundas dos sítios. A composição da terra preta contribuir da preservação das amostras antigas.

Fig. 6 - Decoração pintada típica da tradição Proto-Tupíguaraní. Vermelho sobre engobo branco e branco sobre engobo vermelho, no Amazonas, Mato Grosso e Rondônia, no Alto-Jiparaná onde é mais antigo (como na subtradição Pintada da tradição Tupíguaraní no sul e sudeste da Faixa Costeira, desde o início até o final (MA-NA-03 / RO-JI-28)). As amostras mais antigas no Litoral estão na fase Irapuã do Rio Grande do Sul, alto rio Uruguai, em sítios sobre as terras altas afastadas do Rio Uruguai, chegando a $3.933 \pm 70$ a.P.

Figs. 7 e 8 - Decoração plástica com tratamento corrugado e corrugado-ungulado, típicas da tradição Proto-Tupíguaraní em Rondônia, alto rio Ji-Paraná e médio Roosevelt (figs. 11-15); como no sul e sudeste da Faixa Costeira, sul-sudeste.

Fig. 9 - O tipo ungulado e sua variedade: regular e irregular, bem marcado e suave; no pescoço ou em todo o corpo; sobre a borda e o lábio simples ou reforçados, decorados com serrungulado, ungulado arrastado e ponteado. 
Fig. 10 - O tipo ponteado e sua variedade, regular em faixa de duas linhas ao longo do pescoço ou mais linhas, cobrindo da borda ao ombro. E o tipo roletado da base ao ombro/borda.

Figs. 11, 12 e 13 - Urnas funerárias do sítio AM-NA-08: decoração plástica corrugada desde a base do ombro, ao longo de um pescoço alongado e borda extrovertida, ou totalmente simples. Coberto totalmente pelo corrugado é menos comum. Região dos rios Roosevelt e Madeirinha (1981 e 1983). Uma das características da cerâmica corrugada da Proto-Tupíguaraní é o tratamento corrugado desde a base do ombro ao lábio, seja pescoço alongado como os ilustrados, seja curto. A base pode ser boleada ou aplanada. No exemplar 11 o bojo é discreto com fundo cônico e base aplanada.

Fig. 14 - Reconstituição física e gráfica - bojo, ombro, pescoço, borda e fundo de vasilhame, por empréstimo mútuo desses detalhes. Oriundos de Rondônia / Alto-Jiparaná, Mato Grosso e Amazonas, estes tipos de vasos cerâmicos de bojo arredondado e fundo cônico têm variantes no tempo e no espaço. São elaborados com roletes de argila arenosa fina e grossa, sobrepostos com o corrugado, corrugadoungulado, ungulado, ponteado ou pintado, banho/engobo vermelho e branco. São mais bem-elaborados pela tradição Tupíguaraní da Faixa Costeira (Pronapa, Propa e Pronapaba, GERO e Eletronorte, 1964 - presente). Pela comprovação da existência de correlações entre as cerâmicas e falantes Tupí-Guaraní e datações de ambas as regiões, a presença da tradição Proto-Tupíguaraní na "terra natal" do tronco Tupí é um fato. Pela ocorrência em Rondônia de datações C-14 em sítios-habitação cerâmicos há mais de 5.000 anos a.P, é sugerido o marco entre o pré-cerâmico/pré-agrícola e o précerâmico/agrícola aos ca. 5.210; e entre o pré-cerâmico/agrícola e o agrícola/cerâmico aos ca. 5.070 anos a.P., para a tradição Proto-Tupíguaraní e, talvez, para os falantes de um pré-Proto- Tupí o que levaria o Proto-Tupí para datas anteriores a 5.210 a.P.

Fig. 15 - Aspecto da cerâmica corrugada encontrada no médio rio Roosevelt. Exemplar do sítio AM-NA-08: terra preta, em restauração. Receptáculo do enterramento no. 2, fig. 11 (1981).

Fig. 16 - Fragmento de lâmina de machado com as aletas partidas, da tradição ProtoTupíguaraní. De centenas de exemplares com tratamento alisado, este apresenta ambas as faces com linhas incisas. Na posição da imagem, cada face apresenta ao centro um conjunto de linhas paralelas horizontais e verticais sobrepostas como "esteira ou peneira": (1) ladeada por faixas com círculos concêntricos incisos, donde (2) dois conjuntos laterais de linhas paralelas verticais cruzadas por linhas oblíquas incisas, provavelmente completando o contorno.

Fig. 17 - Lâmina de machado, completa com aletas e tratamento alisado; frequente na tradição Proto-Tupíguaraní no Alto-Jiparaná. Esquematicamente a mesma forma do exemplar da fig. 16. 
Fig. 18 - Material lítico de expediente das culturas Pacatuba pré-cerâmica (fundo preto) e Massangana pré-cerâmica com agricultura (fundo branco). O mesmo tipo de material lítico de ambas sugere uma transição cultural evoluindo para a agricultura. A Pacatuba teria se desenvolvido no auge do Optimum Climático e a Massangana no final desse episódio climático. Enquanto as demais áreas-chave $1 \mathrm{e}$ 5 sentiram o drástico impacto climático Sinimbu-Bacabal, da coluna 4, a da coluna 6 não registrou fortes alterações nas sequências dos seus sedimentos antropogênicos. A cultura Massangana possui os mesmos artefatos líticos da Pacatuba, porém em grande quantidade na camada de terra preta. A terra preta numa cultura pré-cerâmica é a grande diferença, pois indica o início da prática da agricultura, transição do nomadismo para o semi-sedentarismo, sem o acompanhamento cerâmico, dos simples acampamentos sazonais para os primeiros aldeamentos por uma dezena ou mais de anos, do simples bando familiar para uma sociedade mais organizada e menos simples.

Fig. 19 - Registro fotográfico, pela Comissão Rondon, de uma maloca Kepkiriwát, ou Tupítuparí arqueológico, falantes de uma língua da família Tuparí (Rodrigues, com. pessoal). O mais significativo arqueologicamente é o grande pote cerâmico, com a boca encoberta e a trama de cordas ao longo do corpo para transportá-lo, não visível em detalhe. Para mantê-lo de pé, terra foi chegada e socada no entorno da base. Etnograficamente também nos dá informações de uma de suas malocas (acervo iconográfico da Missão Rondon).

Fig. 20 - Duas formas de grandes potes dos Kepkiriwát, falantes Tupí-Tuparí. Imagem parcial destacada e ampliada da Fig. 19, que pode auxiliar na identificação da cerâmica arqueológica retroativamente a A.D. 1913 (acervo iconográfico da Missão Rondon).

Figs. 21 e 22 - Dois recipientes cerâmicos pertencentes tipologicamente à cultura Tupítuparí arqueológica, falantes de língua da família Tuparí, assentada no vale do rio Djaruaréb (Apediá ou Pimenta Bueno), muito antes da chegada da Missão Rondon. Fazem parte de um conjunto de vasilhame pertencente a um enterramento secundário, encontrado a beira de estrada, recuperado por: José S. Garcia e Maria C. Oliveira. Foto por E. Th. Miller e equipe da UNIR.

Fig. 23 - Análises e restaurações de vasilhames corrugados das urnas funerárias do sítio AM-NA-08 e 09 nas figs. 11, 12 e 13 (1981-84). Lab. Arqueológico SECET/GERO.

Fig. 24 - Croqui (cópia, Rio, nov. 44, por J. B. Faria. de mapa original da Missão Rondon/1913) contendo o registro da localização de 50 malocas (Tupí-GuaraníKawahíb, Tupí-Tuparí, Nambikwára e outras). Conjunto de evidências fundamentais para os primeiros reconhecimentos em 1974/75 sobre as semelhanças da cerâmica corrugada e pintada da tradição Tupíguaraní do sul da Faixa Costeira, com a cerâmica corrugada e pintada de um sítio arqueológico Proto-Tupíguaraní. O referido sítio 
estava perto de uma das malocas Kepkiriwát da família Tuparí, situadas próximo do rio Melgacinho e do Marco Rondon de que leva o nome.

Fig. 25 - Estratigrafia do sítio pré-cerâmico RS-LN-01: Cerrito-Dalpiaz. Os estratos com arqueologia se destacam dos estratos estéreis (com infiltrações arqueológicas) resultantes de impactos climáticos severos. Na base do Período 1 ocorrem traços de cinza vulcânica do Chile.

Fig. 26 - O PROPA ensejou a descoberta em 1974-1977 do Complexo Dourado, Paleoíndio, estendido desde ao menos $20.000\left({ }^{14} \mathrm{C}\right)$, aos $6,2 \mathrm{~m}$ de profundidade. Estimado por sondagem desde o final do Pleistoceno, ca. 30.000 anos a.P., e ao longo do Holoceno até as culturas Poaia e Aguapé cerâmicas aos 3.000 a.P. e até aos Nambikwara-Wasusu de A.D.1977.

Fig. 27 - Estratigrafia do Sítio RO-PV-08: Monte Castelo, mostrando os estratos correspondentes às fases pré-cerâmicas: Cupim, abaixo do sambaqui (semi-aridez pré Pantanal do Guaporé) e Sinimbu (Pantanal do Guaporé de antes do início ao final do Optimum Climático), o Estrato Guia Sinimbu-Bacabal (semi-aridez) e a fase Bacabal (com o retorno do Pantanal do Guaporé até 800 a.P.).

Fig. 28 - Em 1987, o corte-1 do sítio arqueológico RO-PV-48: Cachoeirinha atingiu $6 \mathrm{~m}$. Sem escoramentos para evitar desmoronamentos, paramos. Do fundo para a superfície do corte ocorreram duas culturas pré-cerâmicas, seguidas de outra pré-cerâmica com terra preta indicadora de reocupações só possíveis com base na agricultura. Depois veio a cerâmica da tradição Jamari eclipsada pelos não-indígenas, ca. 1720 a. D. Esta é a sequência cultural desde o início do $1^{\circ}$ Estágio até o final do $3^{\circ}$ Estágio com a cerâmica Jamarí, do Tupíarikém.

Fig. 29 - Seis sequências cronológicas de áreas-chave para o entendimento da transposição das condições de predadores para produtores, de nômades para semisedentários, de pré-agrícolas e pré-cerâmicos para caçadores agricultores-cerâmistas. Elas foram pesquisadas pelo PROPA e PRONAPABA e outros desde 1959-2007 no Rio Grande do Sul e no Sudoeste Amazônico, no pantanal do Guaporé; nos rios Guaporé, Jamarí, Ji-paraná, Roosevelt, Madeira, Aripuanã, Guaporé/Mamoré, no Abrigo do Sol, MT, Refúgio Guaporé, Refúgio Rondônia-Aripuanã, salvamento arqueológico na UHE Samuel e futura UHE Ji-Paraná/Eletronorte. Essa transição de predador para produtor ainda não está suficientemente entendida; são conhecidas duas culturas relativamente bastante precoces, a Massangana com agricultura e sem cerâmica, com muitas lascas líticas no material de expediente, e a Proto-Tupíguaraní

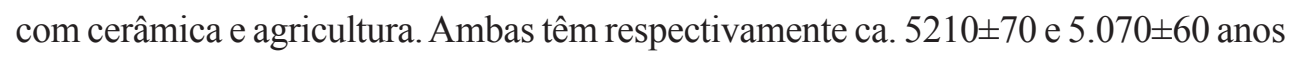
de existência. Essas seis sequências cronológicas culturais e linguísticas apresentam vários impactos climáticos negativos com semi-aridez e um positivo diametralmente 
oposto, o Optimum Climático. Ao longo de suas histórias, procura-se a correlação entre elas e as culturas periodizadas ao longo dos últimos seguramente 20.000 e possivelmente 30.000 anos.

Figs. 30 e 31 - Na Faixa Costeira o Tupíguaraní, principalmente o do sul, em seu rol de expediente sempre apresentou lascas simples e finas, sem retoques, mas com evidências de uso em algumas, por corte e raspagem. Esse é o aspecto da grande maioria delas. $\mathrm{Na}$ Amazônia encontram-se outras culturas cerâmicas com algumas lascas de simples a bem elaboradas (cachoeira Dardanelos no Aripuanã, MT, e Cachoeira Morena no Uatumã, AM), mas principalmente na "terra natal" as lascas estão presentes no rol de expediente do Proto-Tupíguaraní, da superfície à base dos sítios. Retro-pensando e projetando: quem for à procura do progenitor, o pré-Proto-Tupí, caçador-coletor, dos 5200 aos 7000 a.P. encontrará ao menos algumas lascas, núcleos e algum carvão, em sítios-acampamento, principalmente ao longo das corredeiras, por indicador material arqueológico, como as lascas das figs. 30 e 31 em calcedônia, arenito metamórfico, basalto, sílex, etc. Será preciso escavar grandes áreas por debaixo de terras pretas antropogênicas junto às corredeiras da "Área Alto-Jiparaná", para chegar à "terra natal arcaica".

Fig. 32 - Croqui (cópia, Rio, Nov. 44, por J. B. Faria, de mapa original da Missão Rondon/1913, cf. Rondon e Faria, 1948), contendo os extremos do alto rio Ji-Paraná e afluentes, desde a cachoeira do Arregaço até aos baixos cursos do Comemoração e do Pimenta Bueno, onde a Missão Rondon entre 1909 e 1915 encontrou representantes dos Tupí-Guaraní-Kawahib do sul da terra natal, denominados Pauatê, com quatro subgrupos: Majubim, Tacuatêpe, Ipoteuatêpe e Parnauáte. Este mesmo espaço corresponde à Área Alto-Jiparaná arqueológica, centro e origem da tradição ProtoTupíguaraní. Aí, no afluente Melgacinho do Comemoração estivemos em 1975 junto aos primeiros fragmentos corrugados encontrados em Rondônia.

Fig. 33 - Croqui (cópia, Rio, Nov. 44, por J. B. Faria, de mapa original da Missão Rondon/1913, cf. Rondon e Faria 1948), contendo a bacia do rio Jamarí e a localização dos Tupí-Arikém (Arikém e Karitiána). A Comissão Rondon aí esteve de 1911 a 1913. O salvamento arqueológico da UHE Samuel, 1987-88, pesquisou o Massangana e o Jamari, encontrando a mesma tradição Jamari em ambos; essa correlação cultural arqueológica, linguística, etno-histórica e cronológica sugere estarmos em presença de mais um complexo cultural que hipoteticamente virá a ser a tradição Tupíarikém.

Fig. 34 - Os Tupí-Arikém em 1913, na aldeia que Rondon mandou construir junto à estação telegráfica, que denominou de Ariquemes, para abrigá-los e protegê-los dos seringueiros. 
FOTOS

A Cultura Cerâmica do Tronco Tupí no Alto Ji-Paraná, Rondônia, Brasil

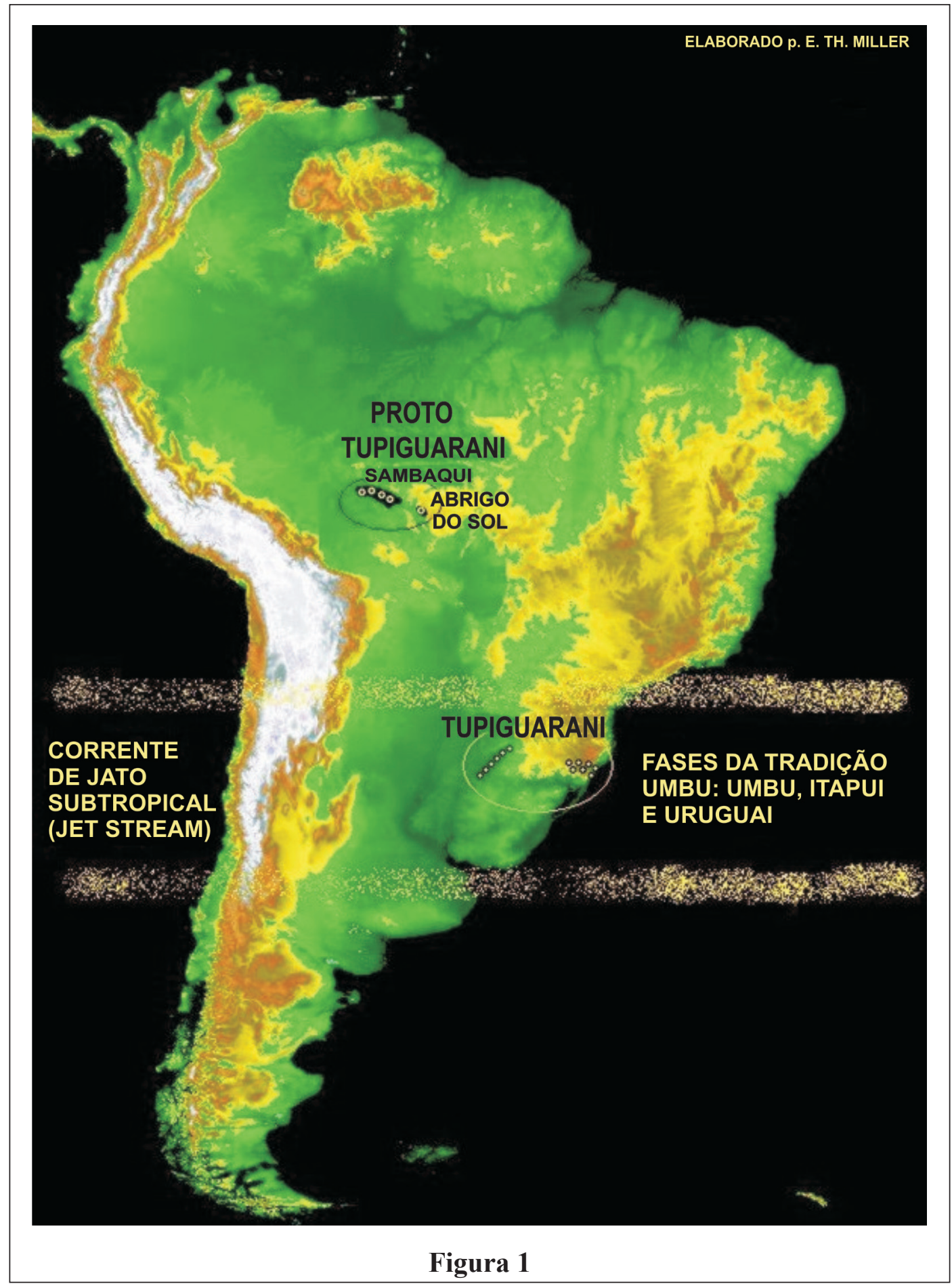




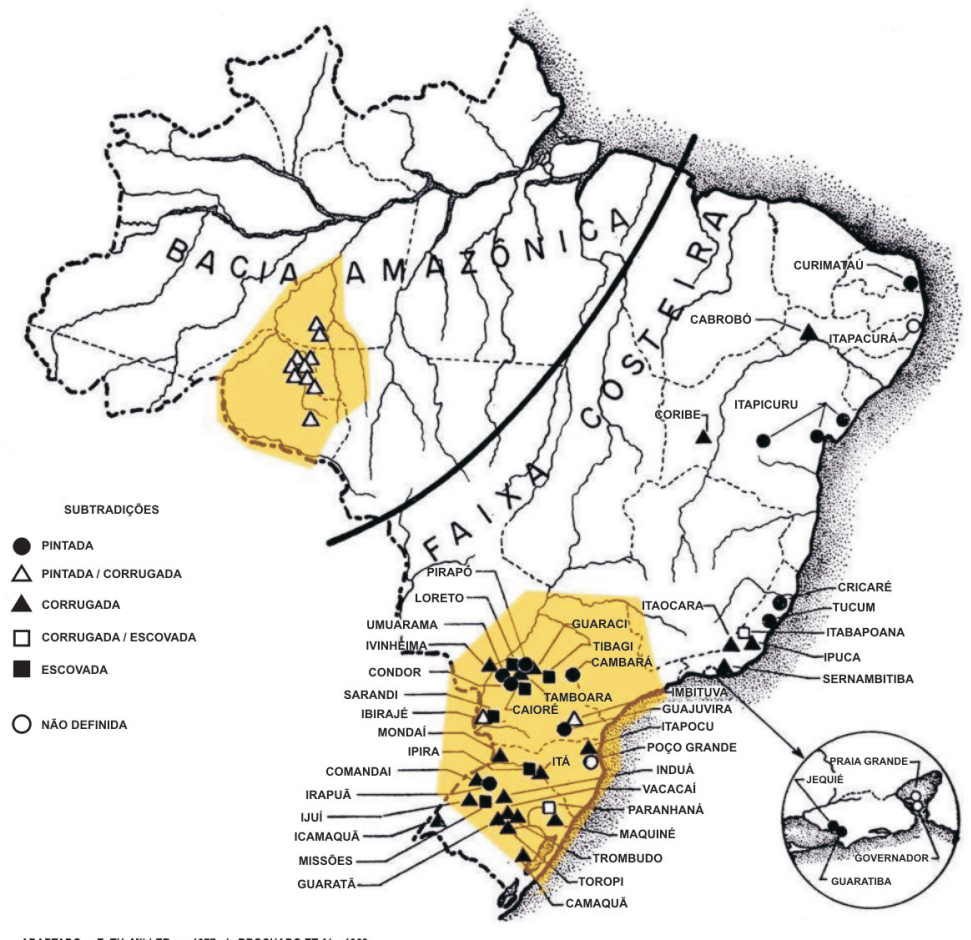

ADAPTADO p. E. TH. MILLER em 1977: de BROCHADO Et AL., 1969,

Figura 2

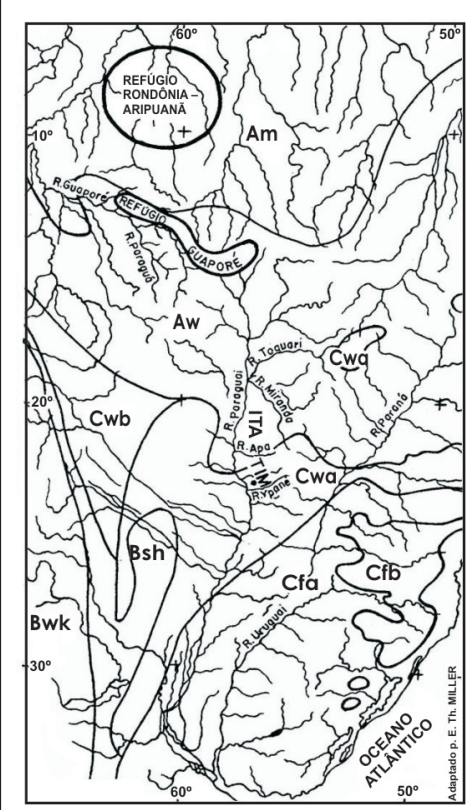

Figura 3a

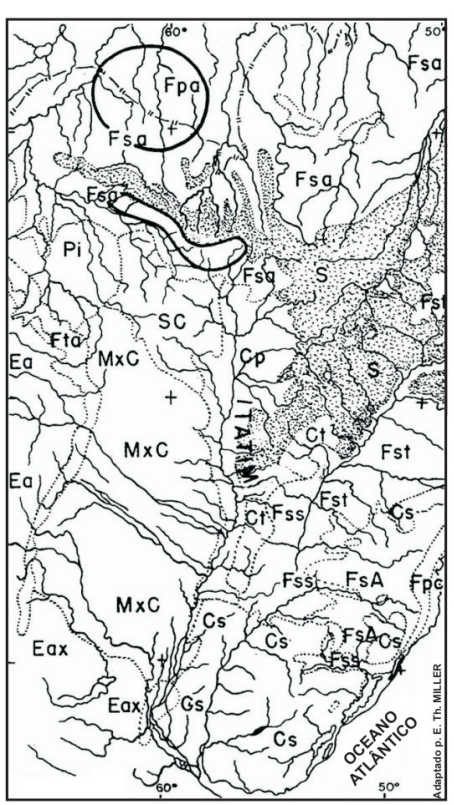

Figura 3b

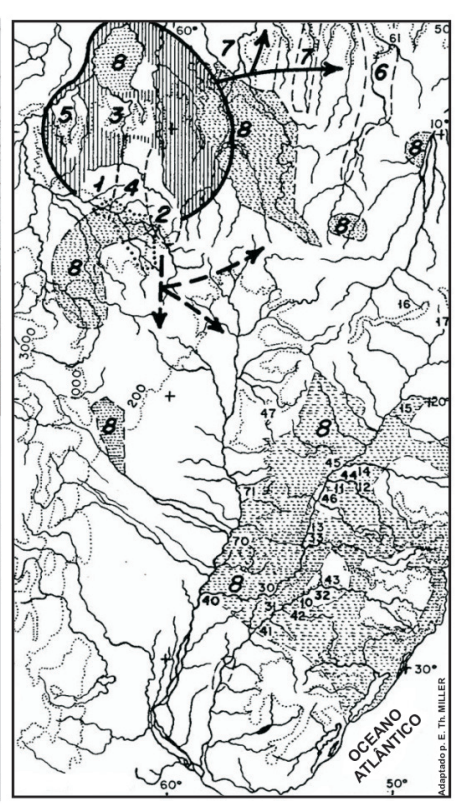

Figura 3c 


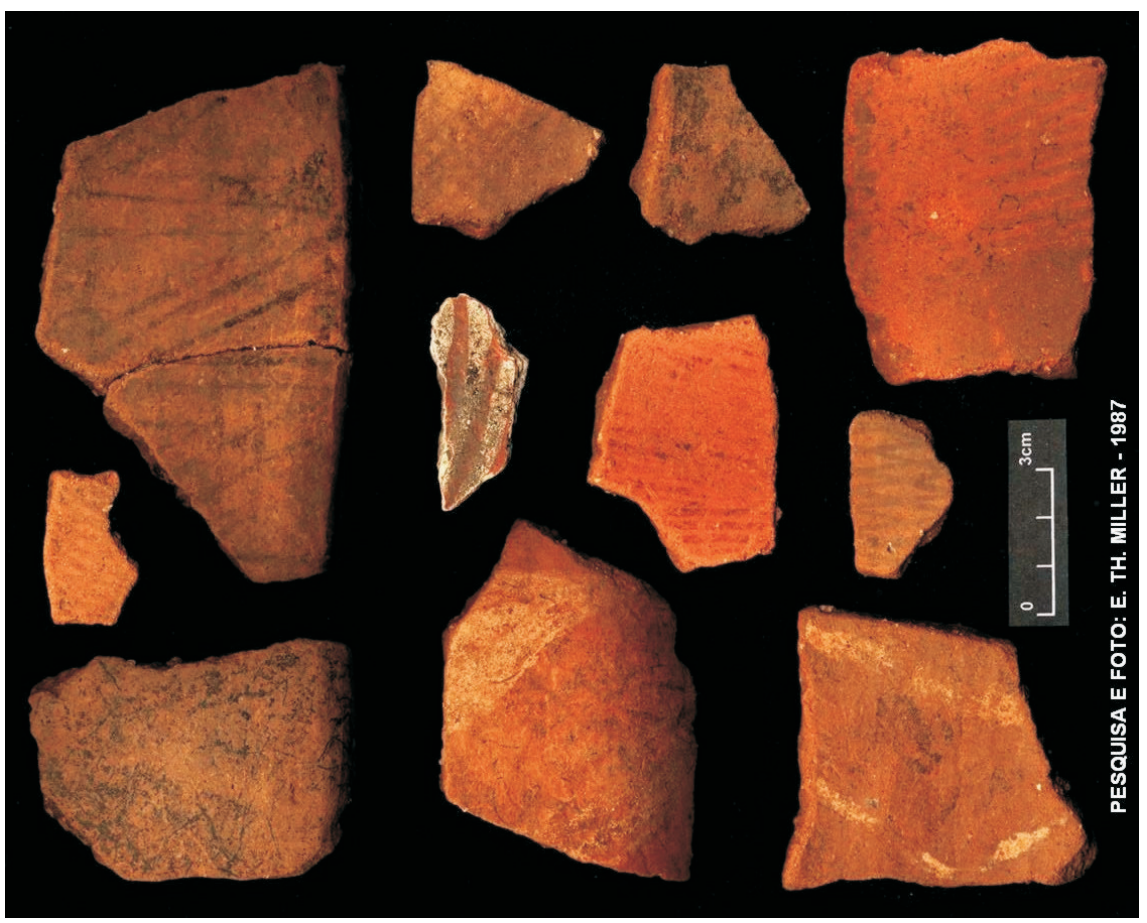

Figura 4

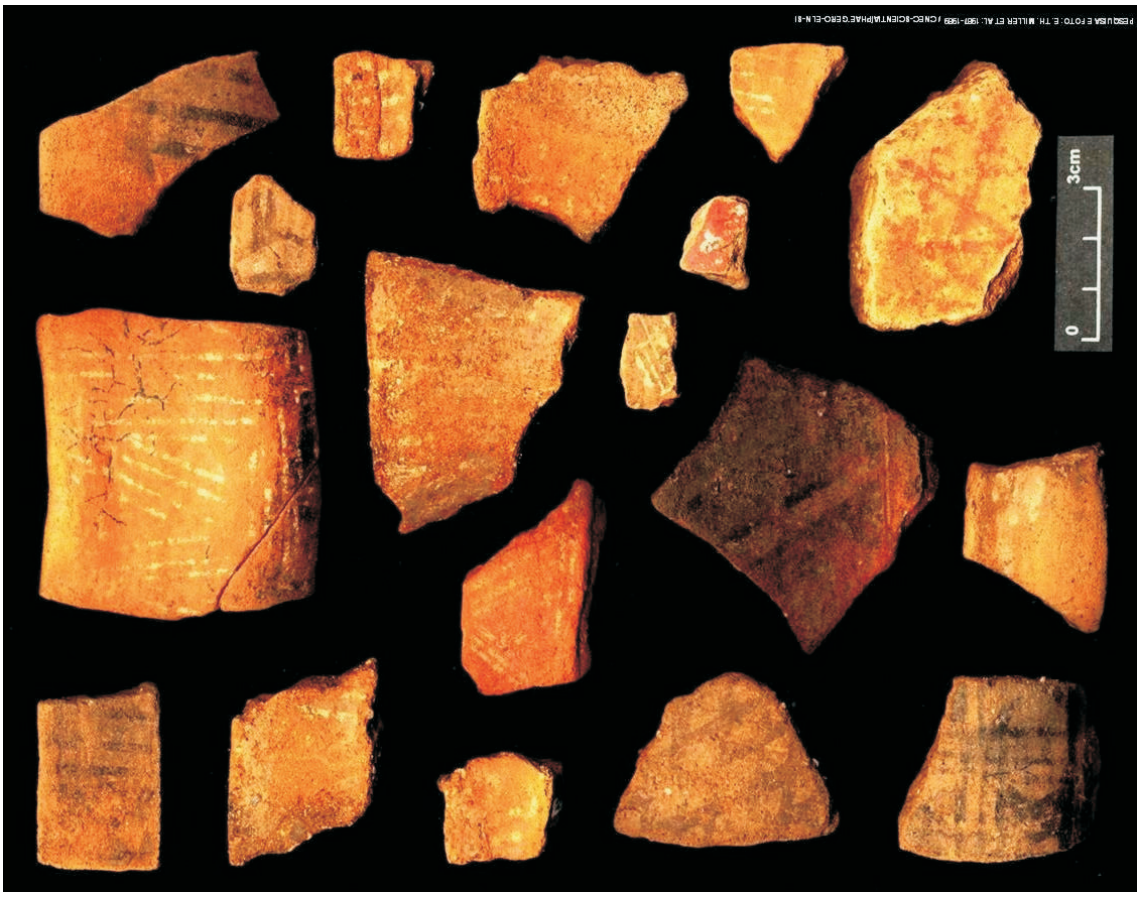

Figura 5 


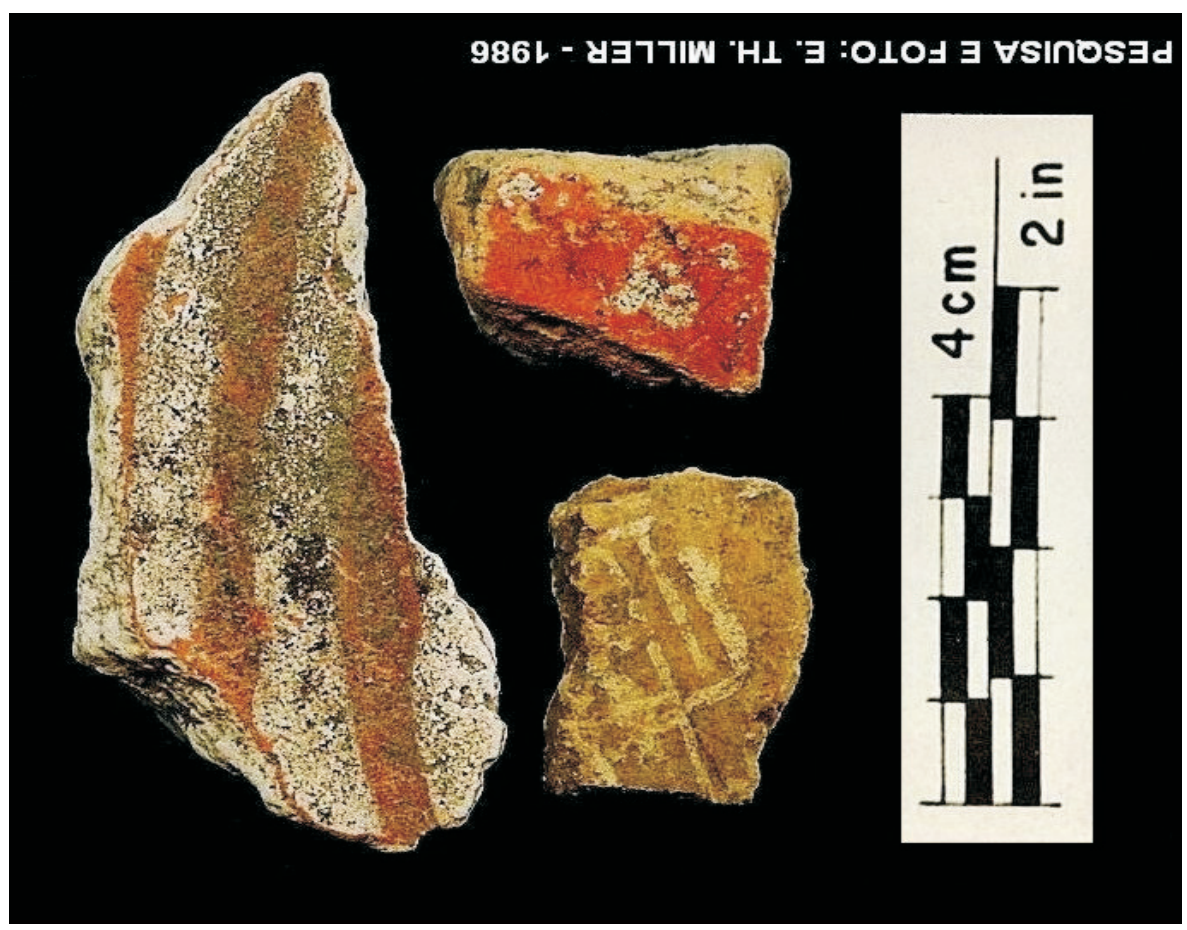

Figura 6

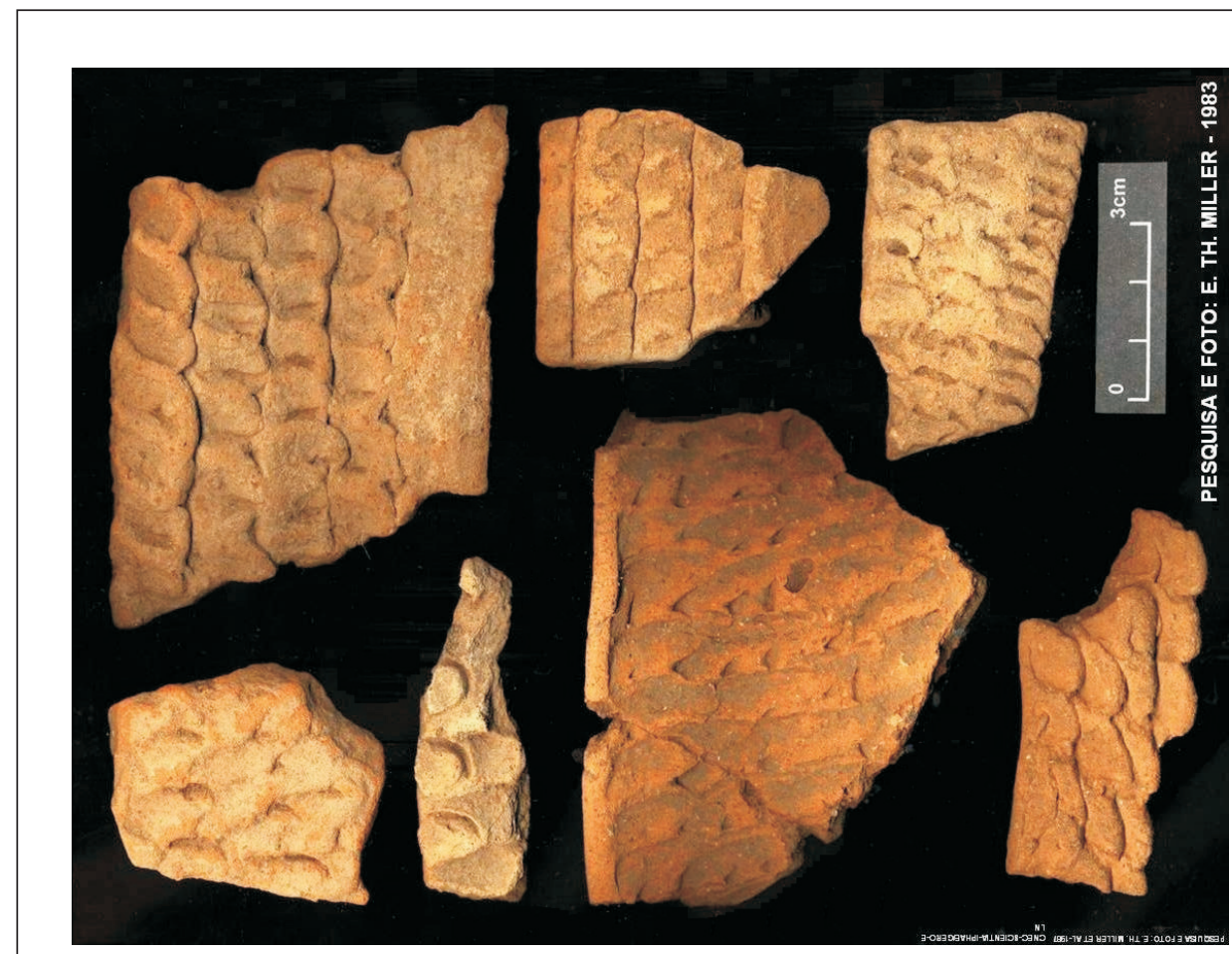

Figura 7 


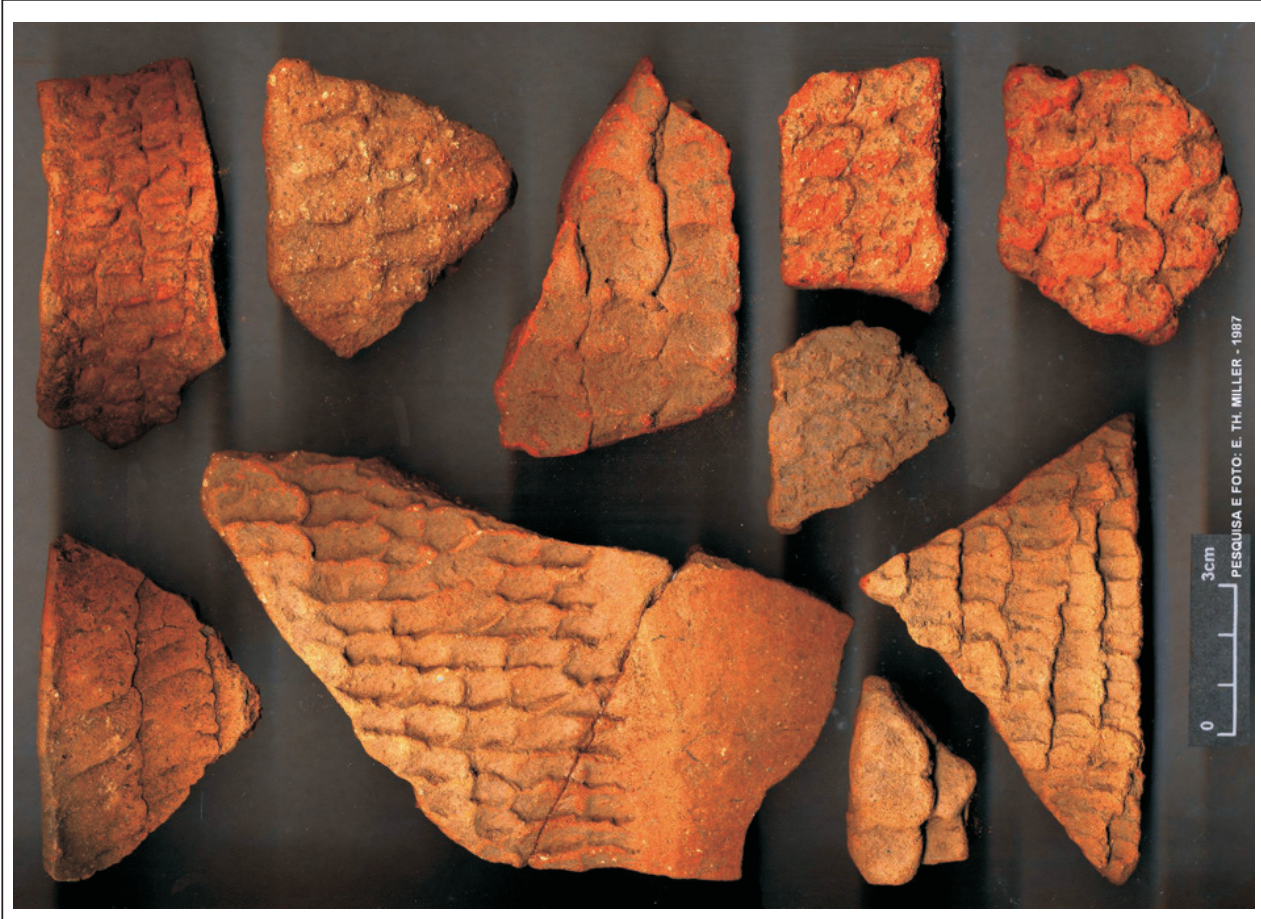

Figura 8

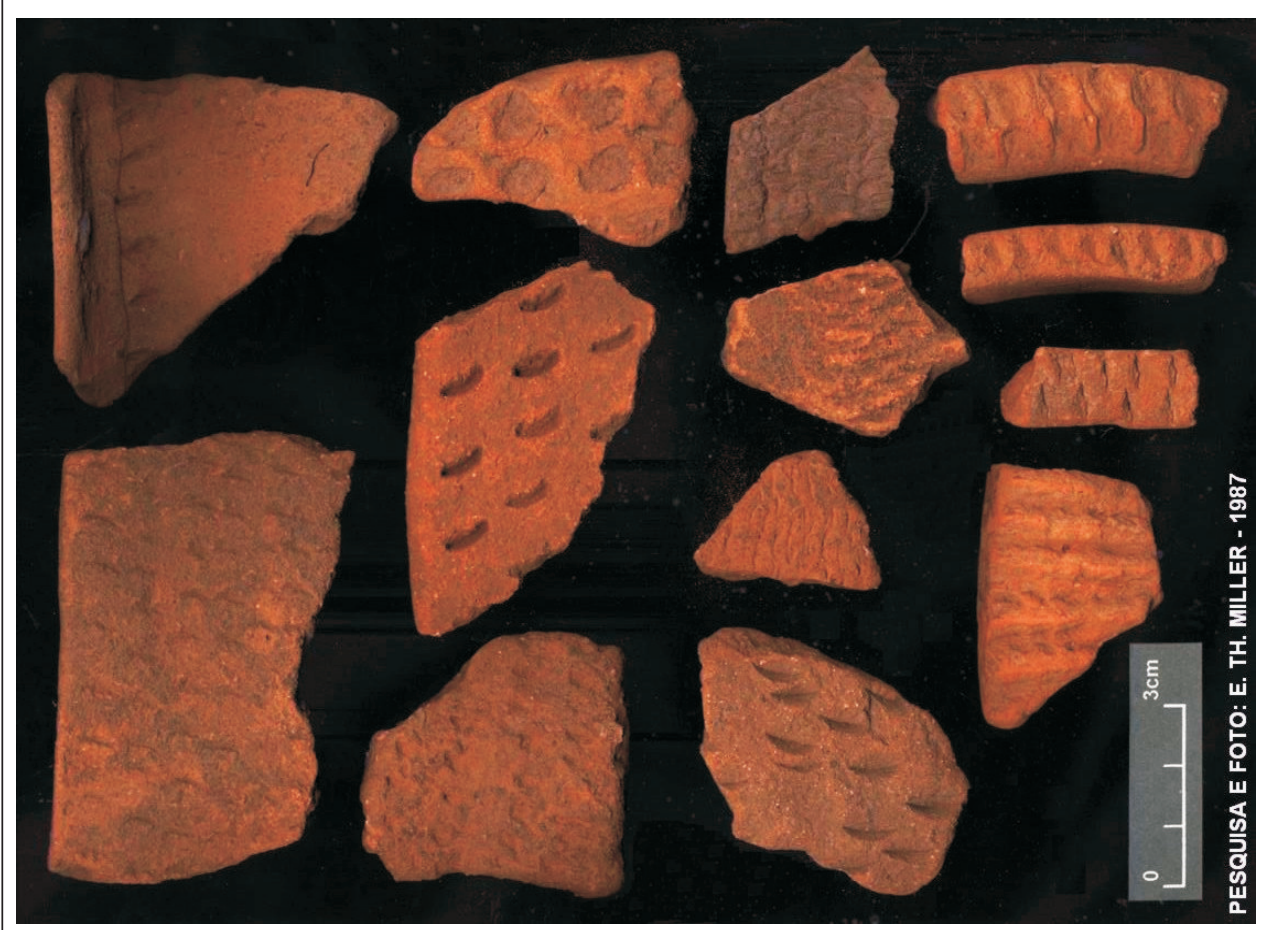

Figura 9 


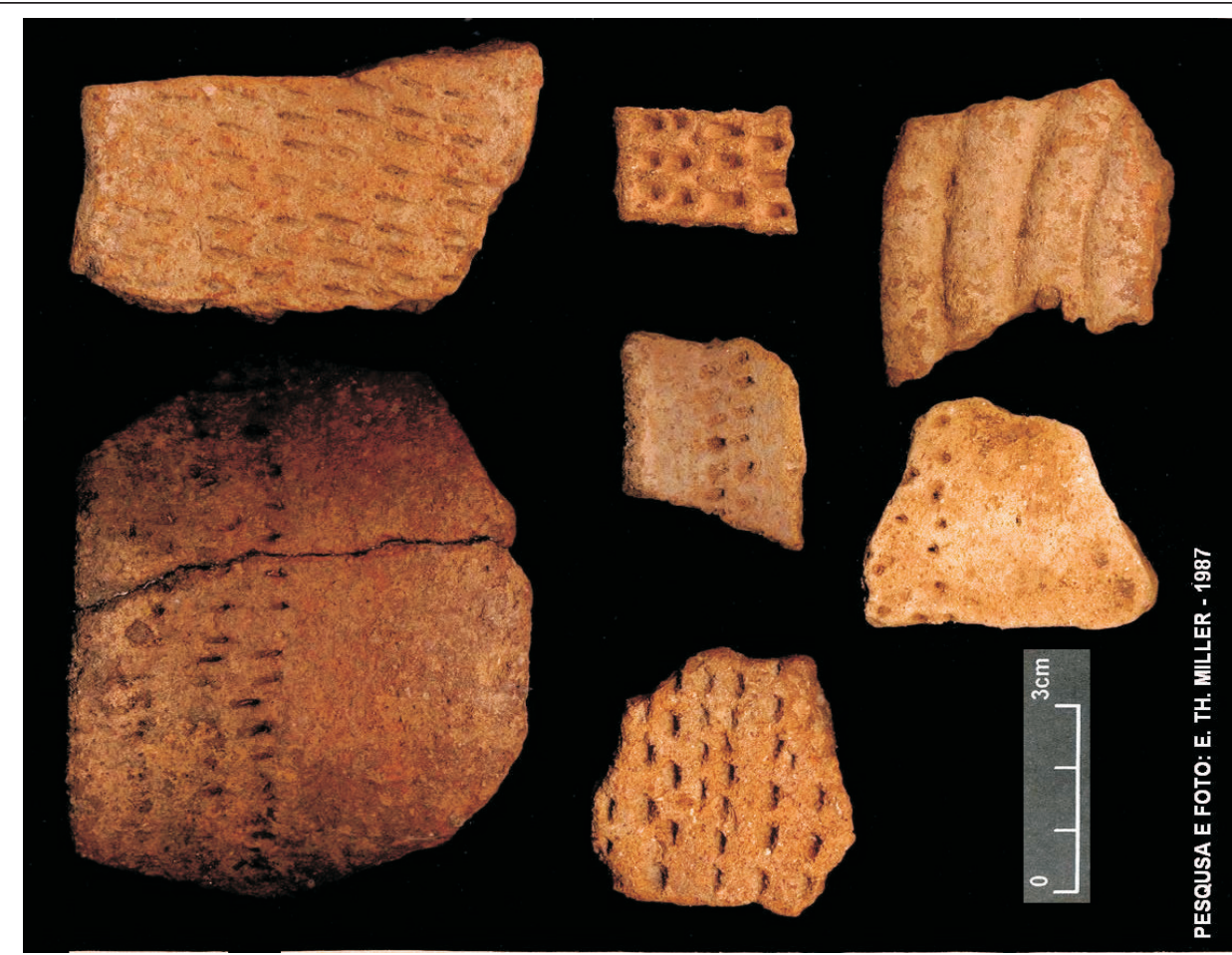

Figura 10

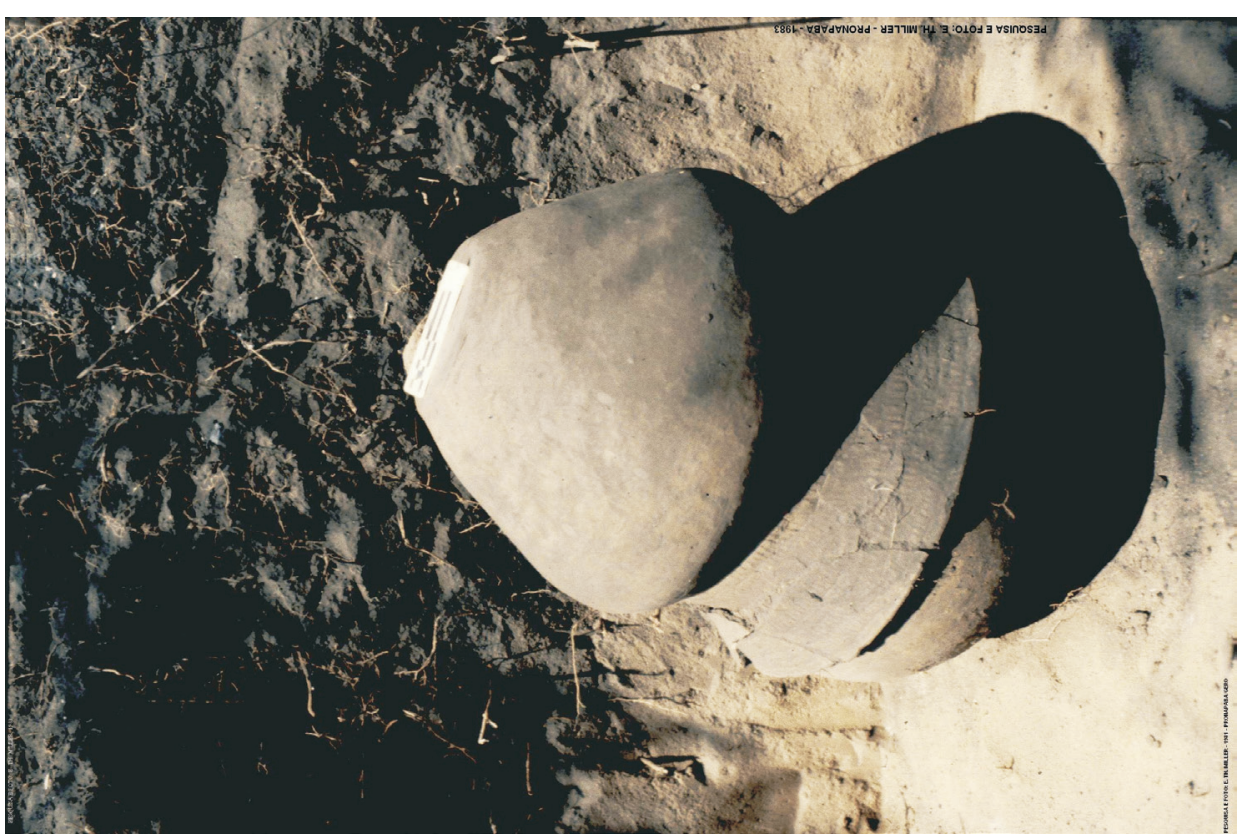

Figura11 

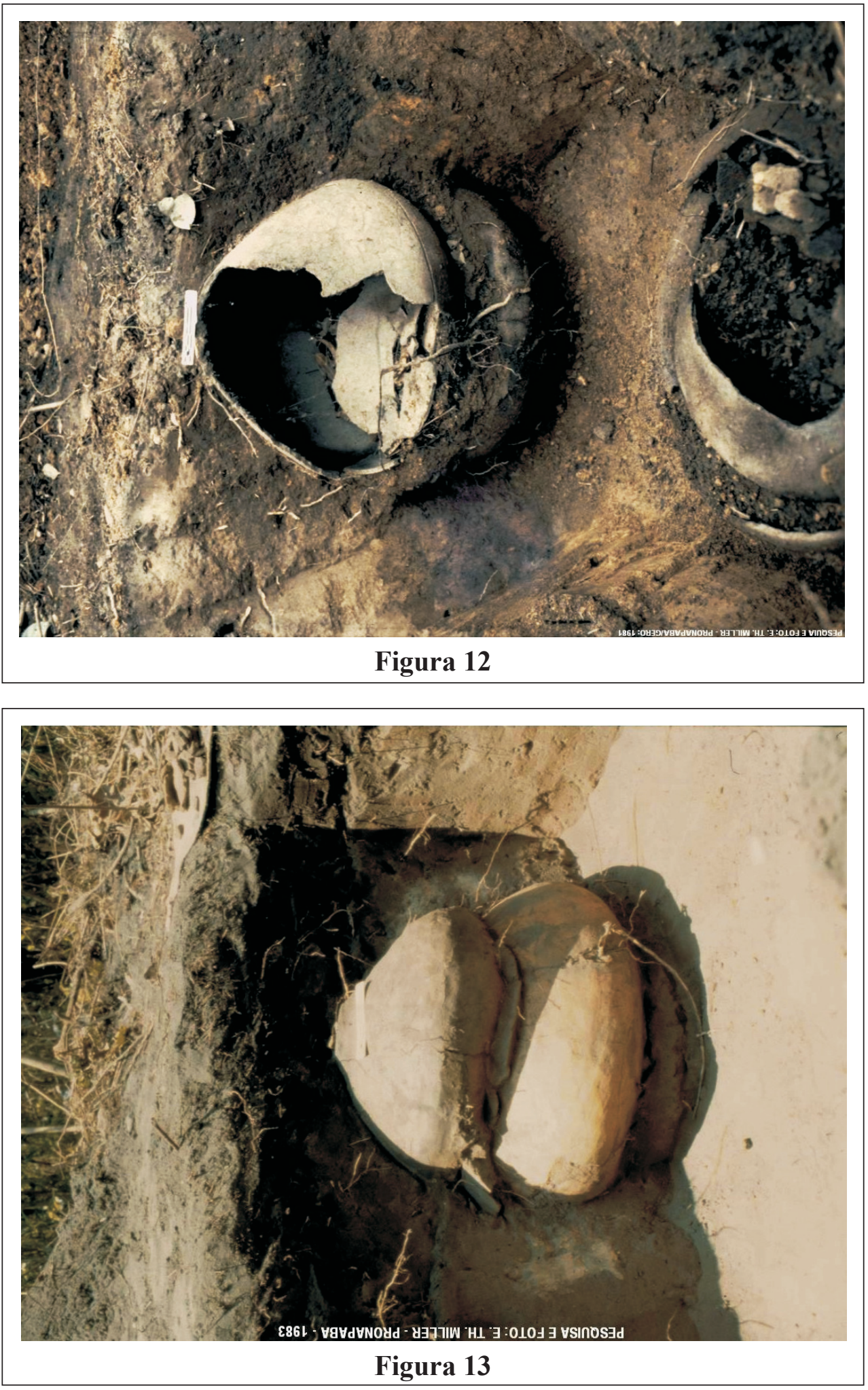

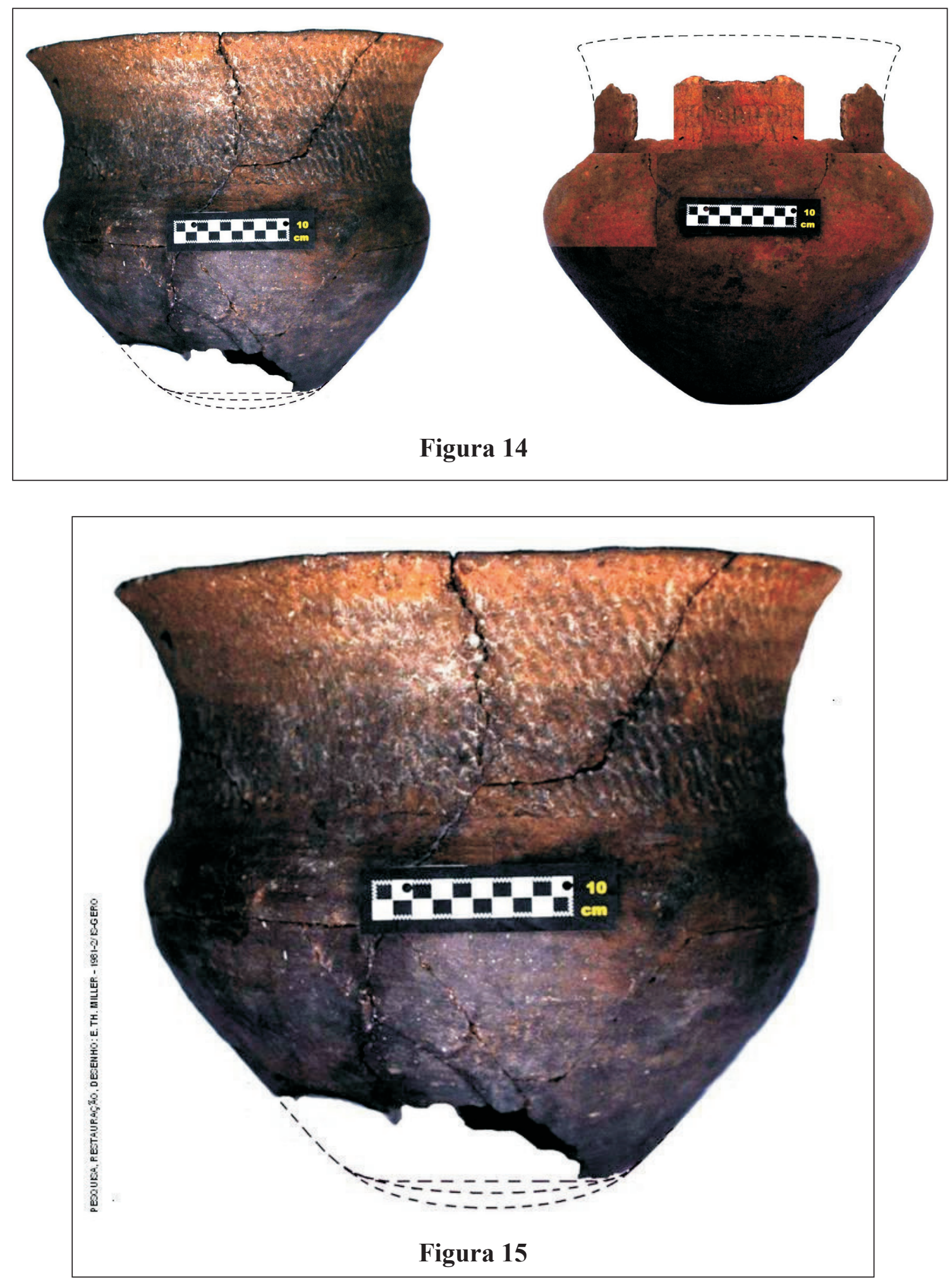

Jul. 2009 | Vol. 1, n. 1 | Revista Brasileira de Linguística Antropológica | 

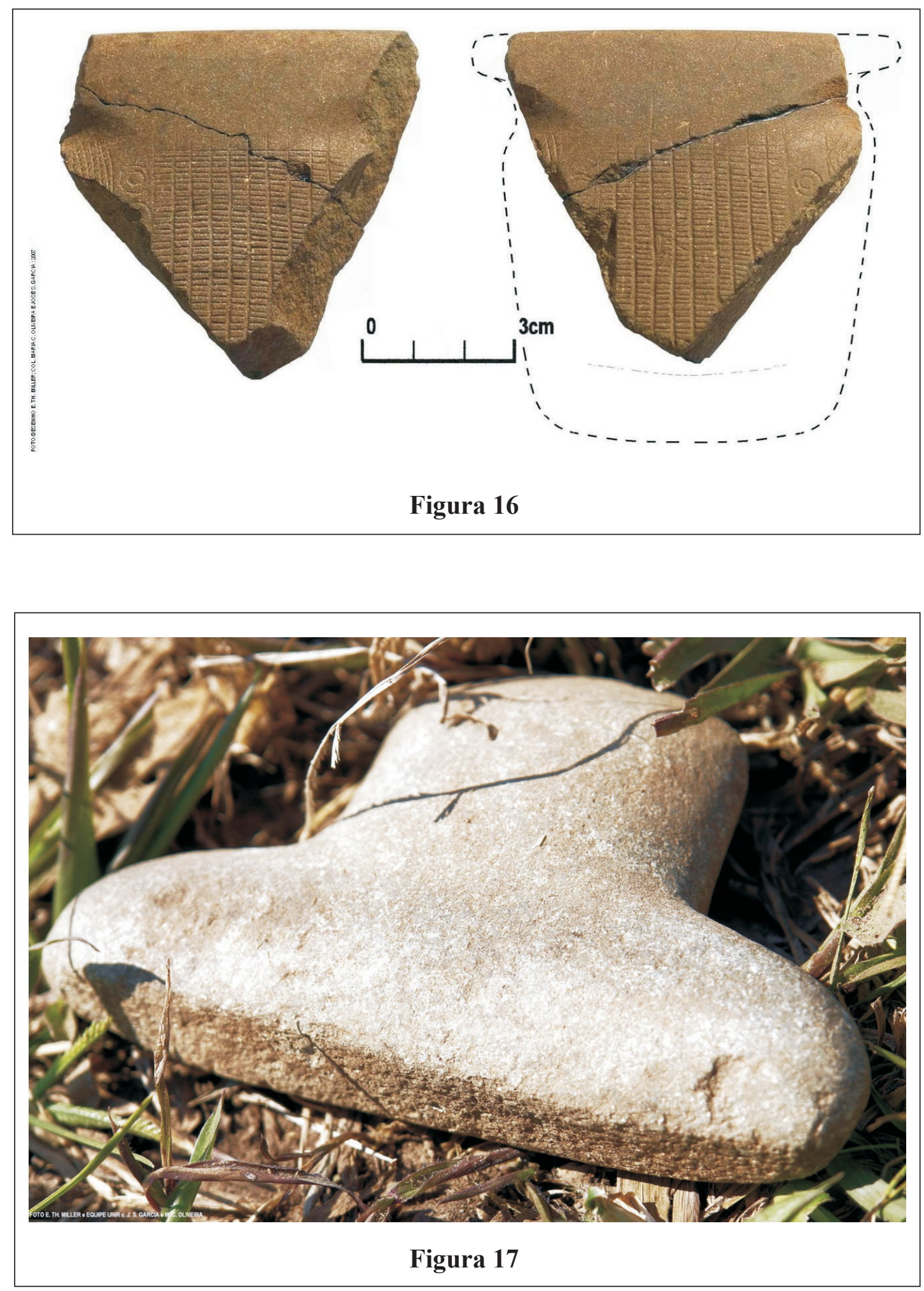


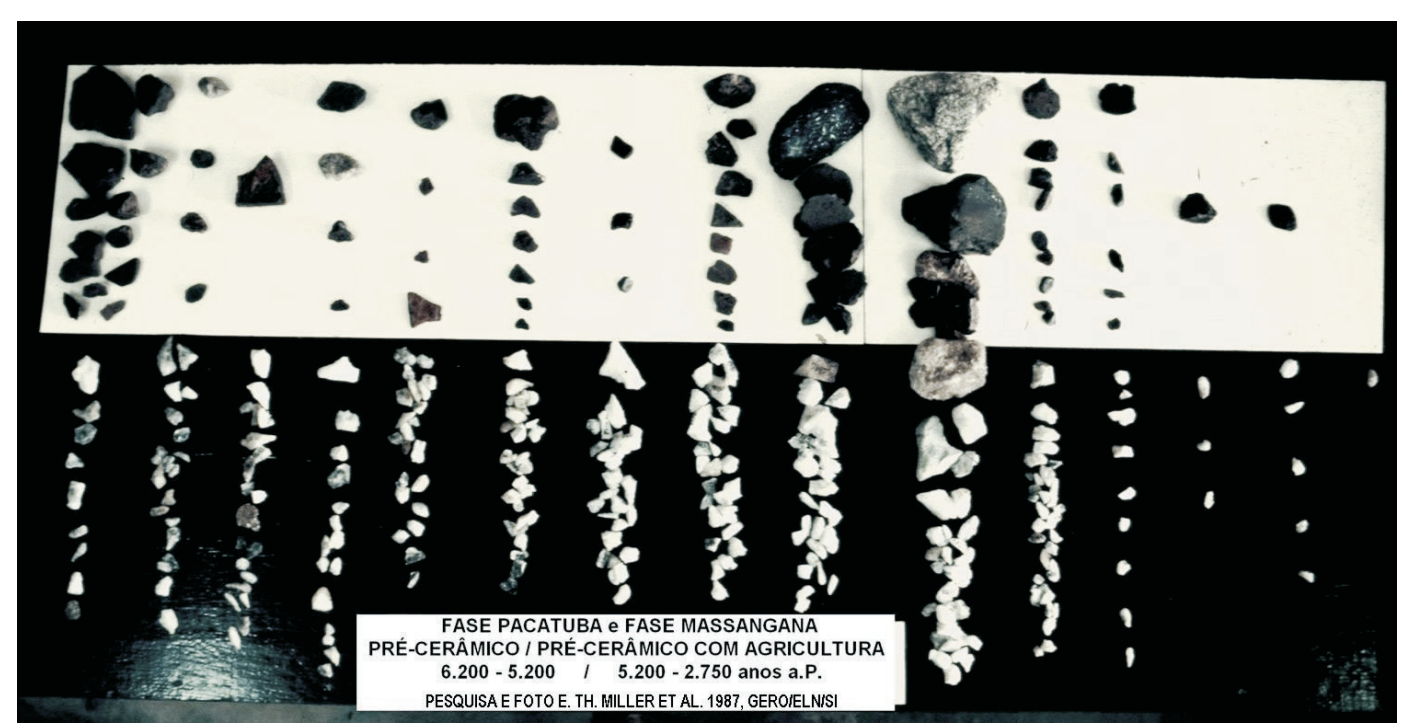

Figura 18

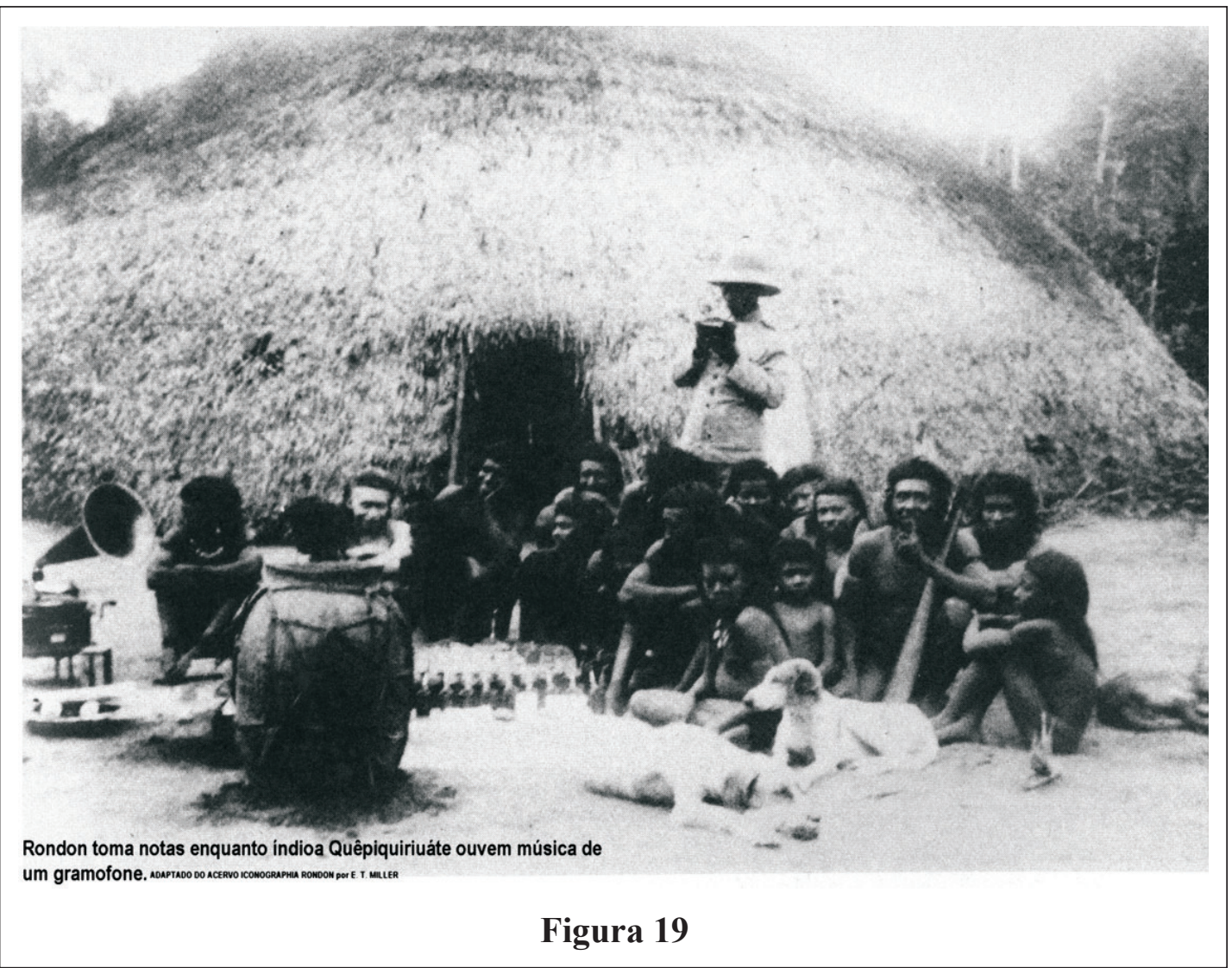

Jul. 2009 | Vol. 1, n. 1 | Revista Brasileira de Linguística Antropológica | 


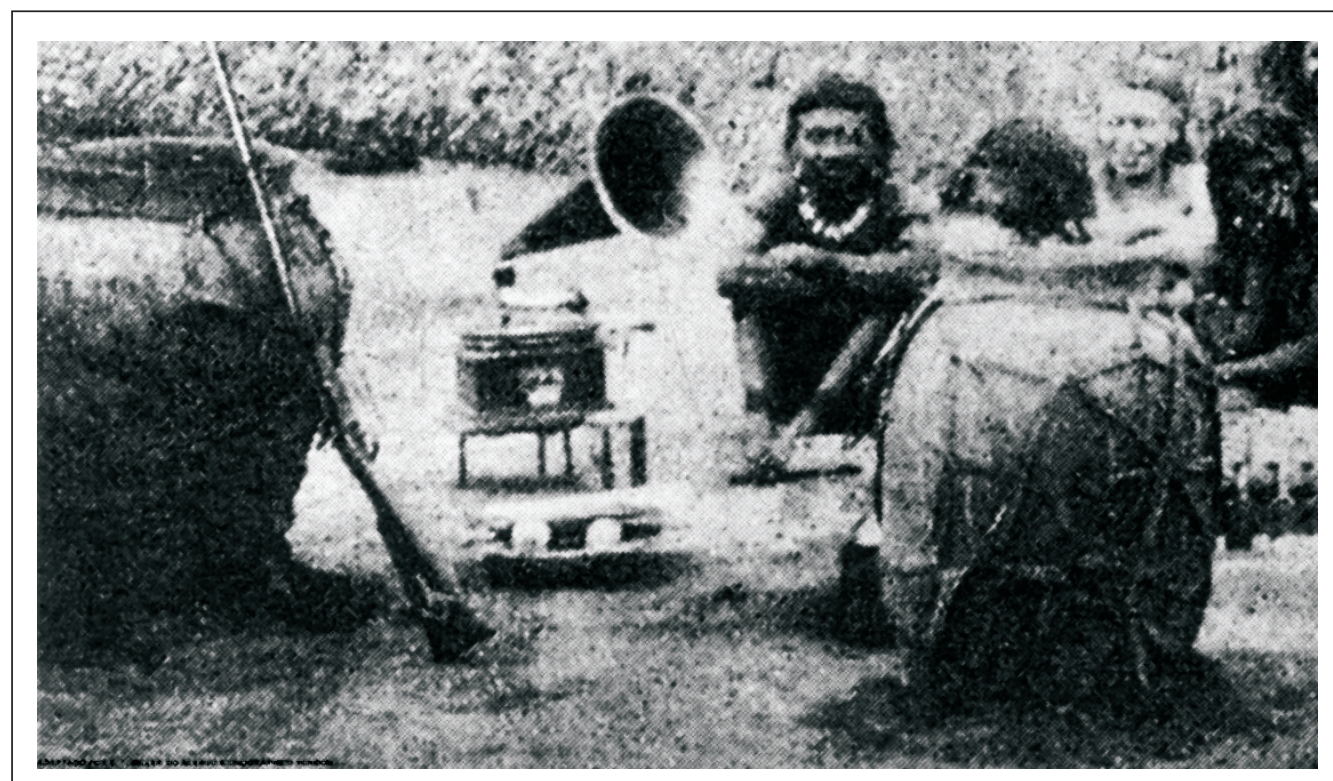

Figura 20

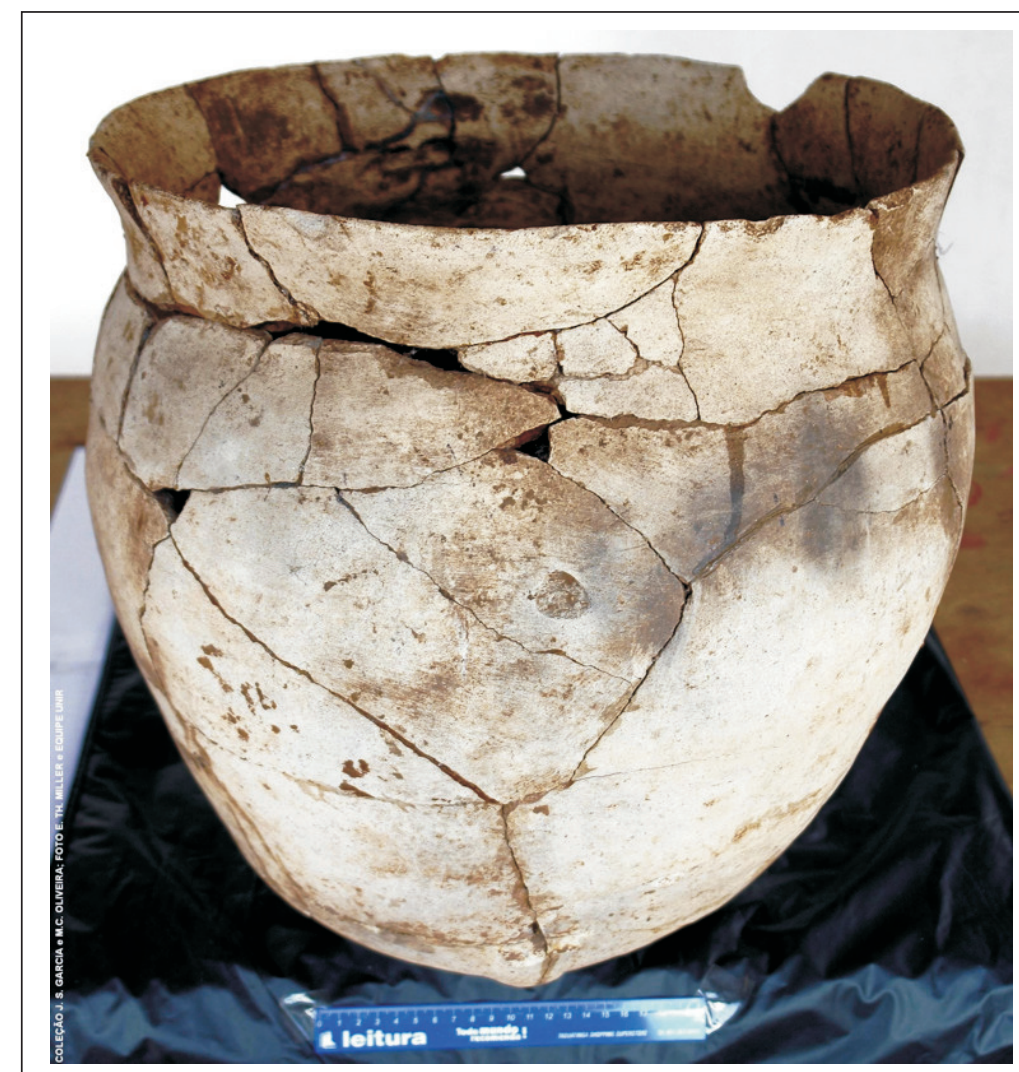

Figura 21 


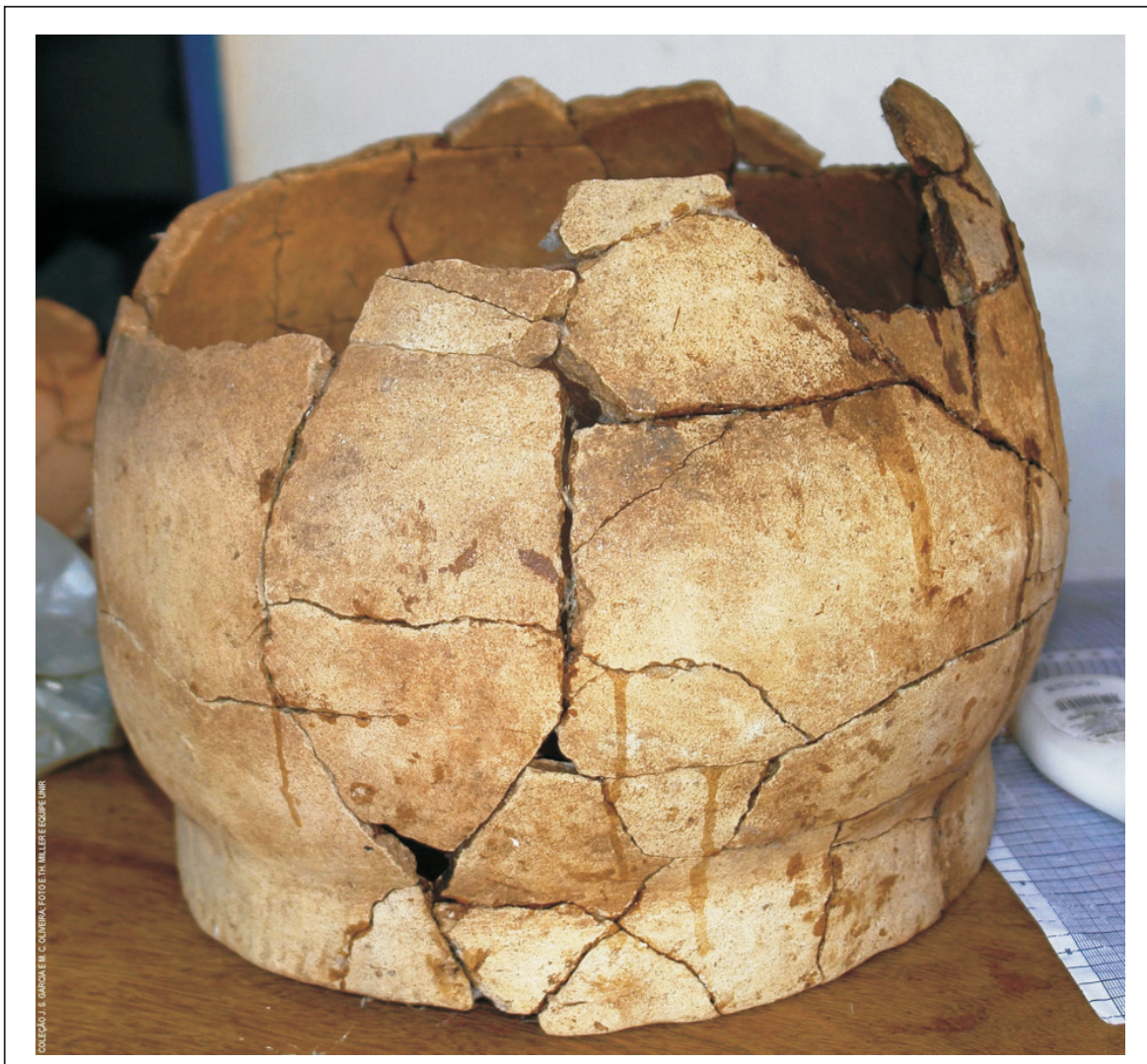

Figura 22

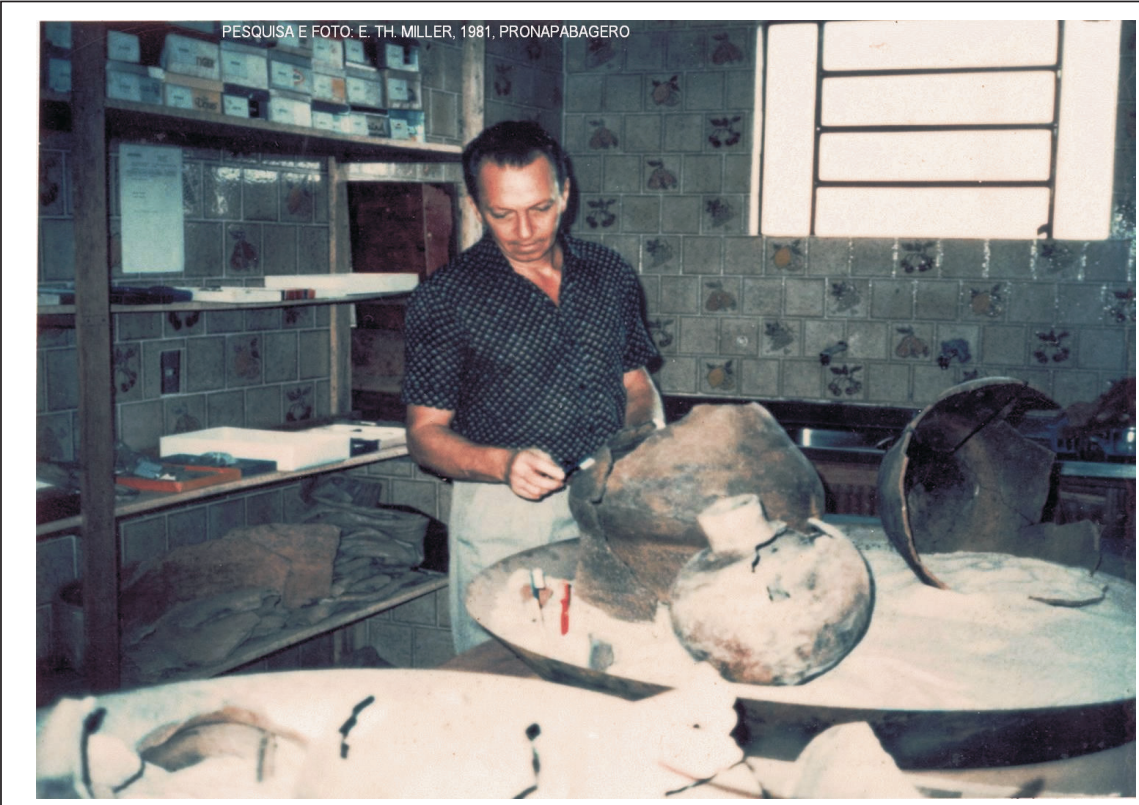

Figura 23 

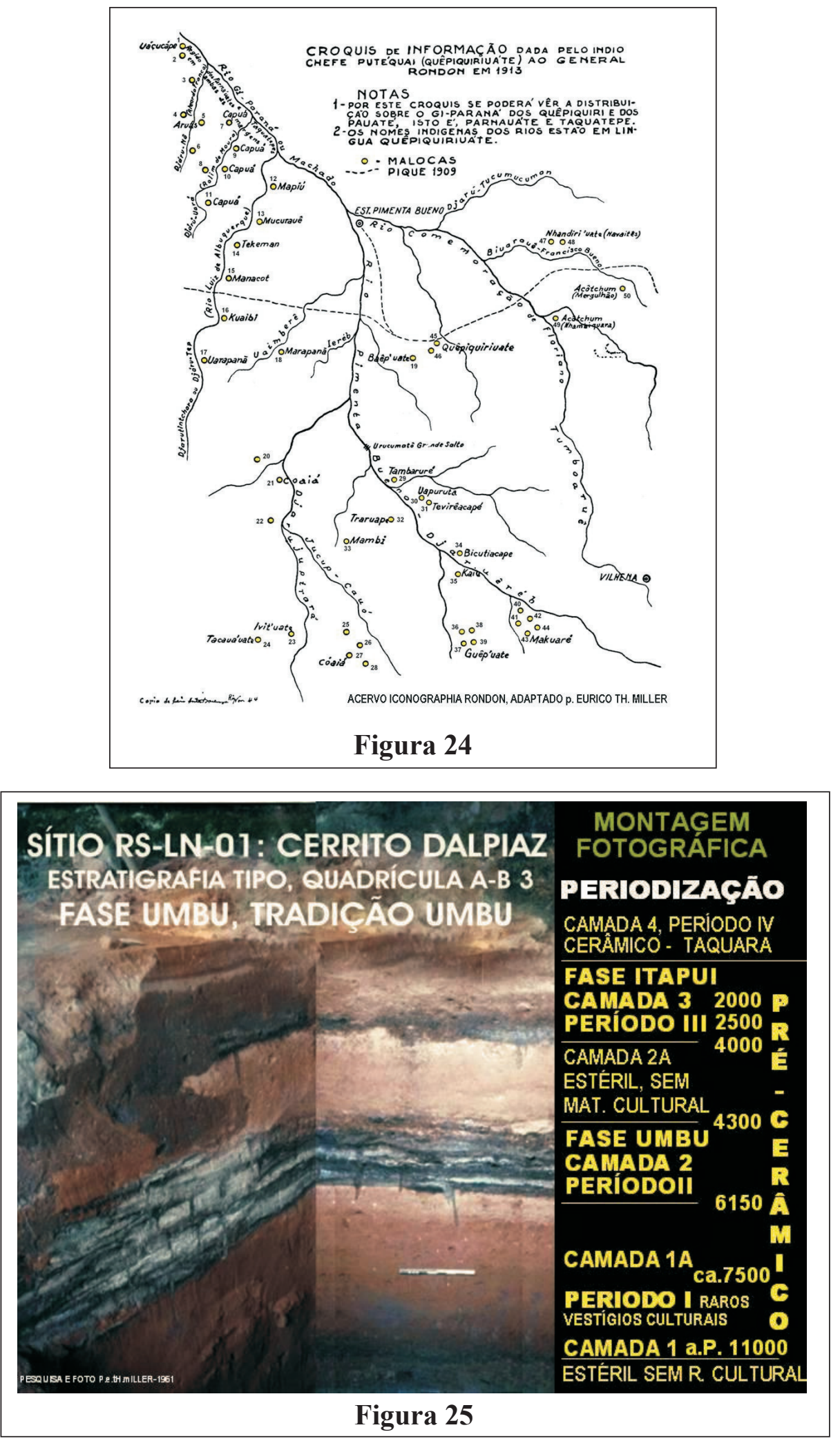


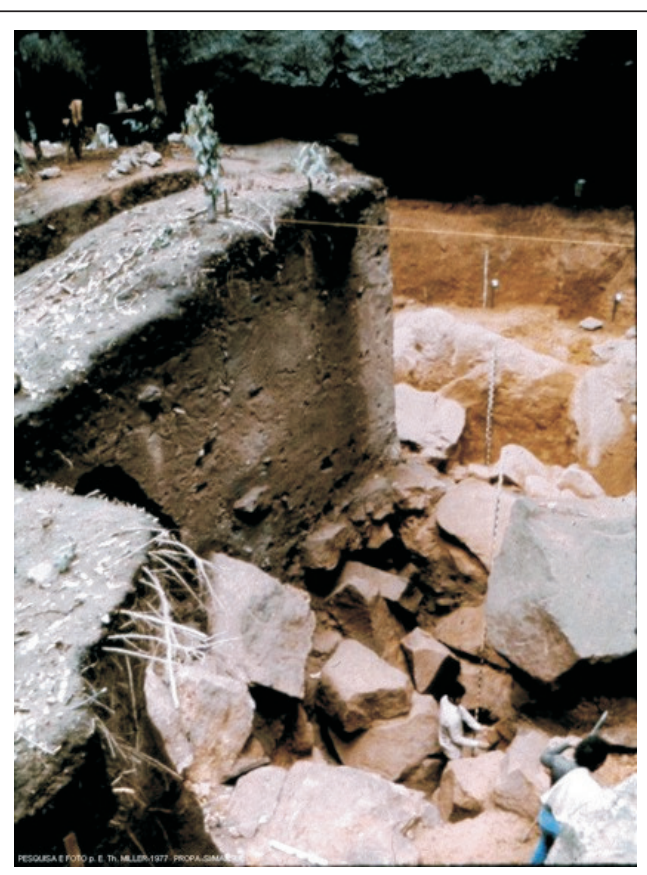

Figura 26

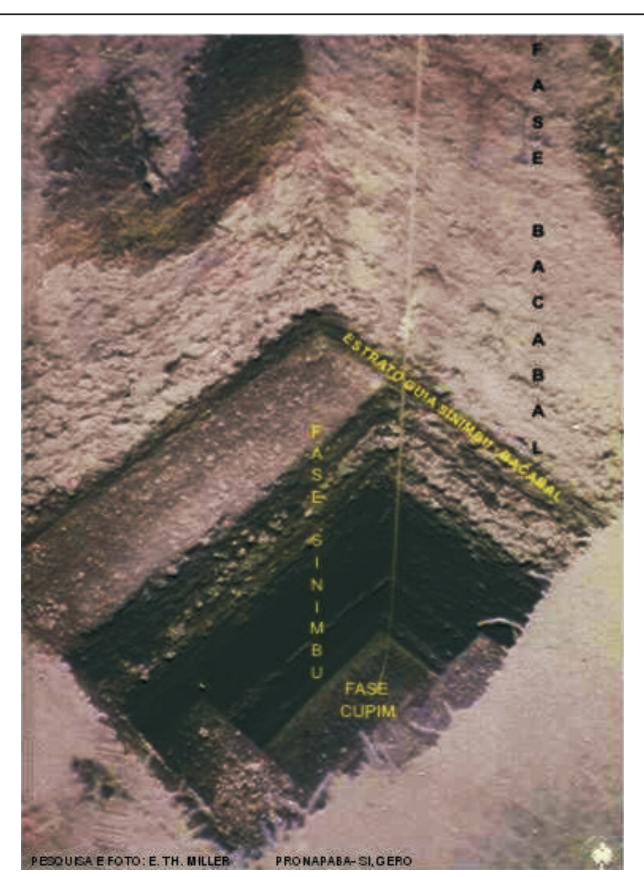

Figura 27

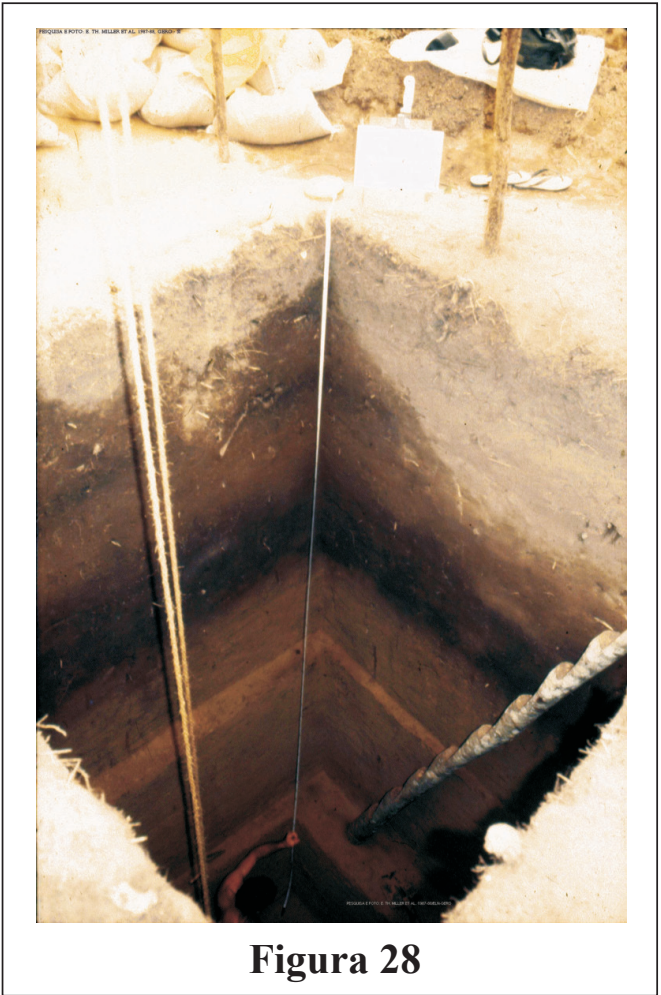

Jul. 2009 | Vol. 1, n. 1 | Revista Brasileira de Linguística Antropológica | 


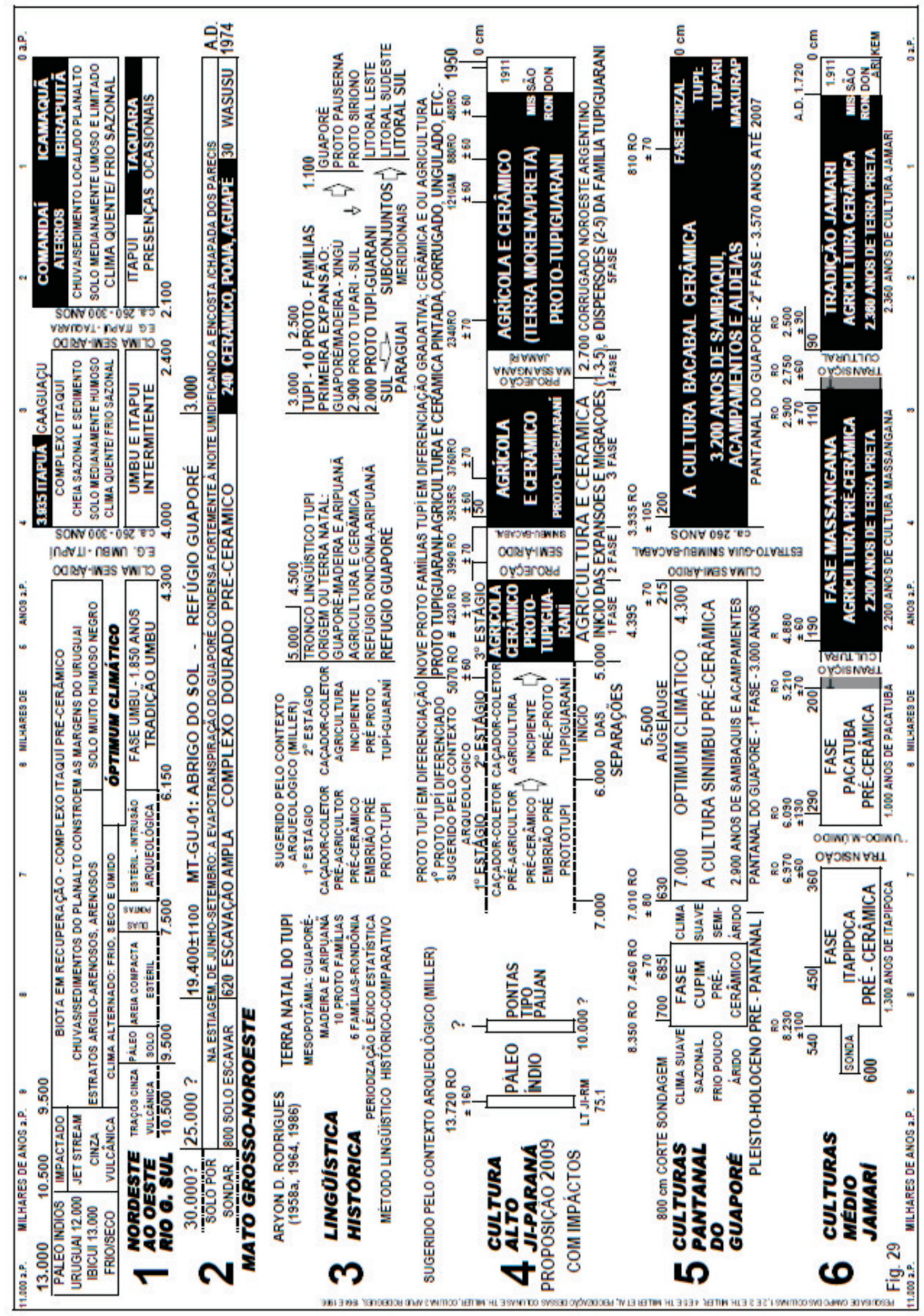

Figura 29 

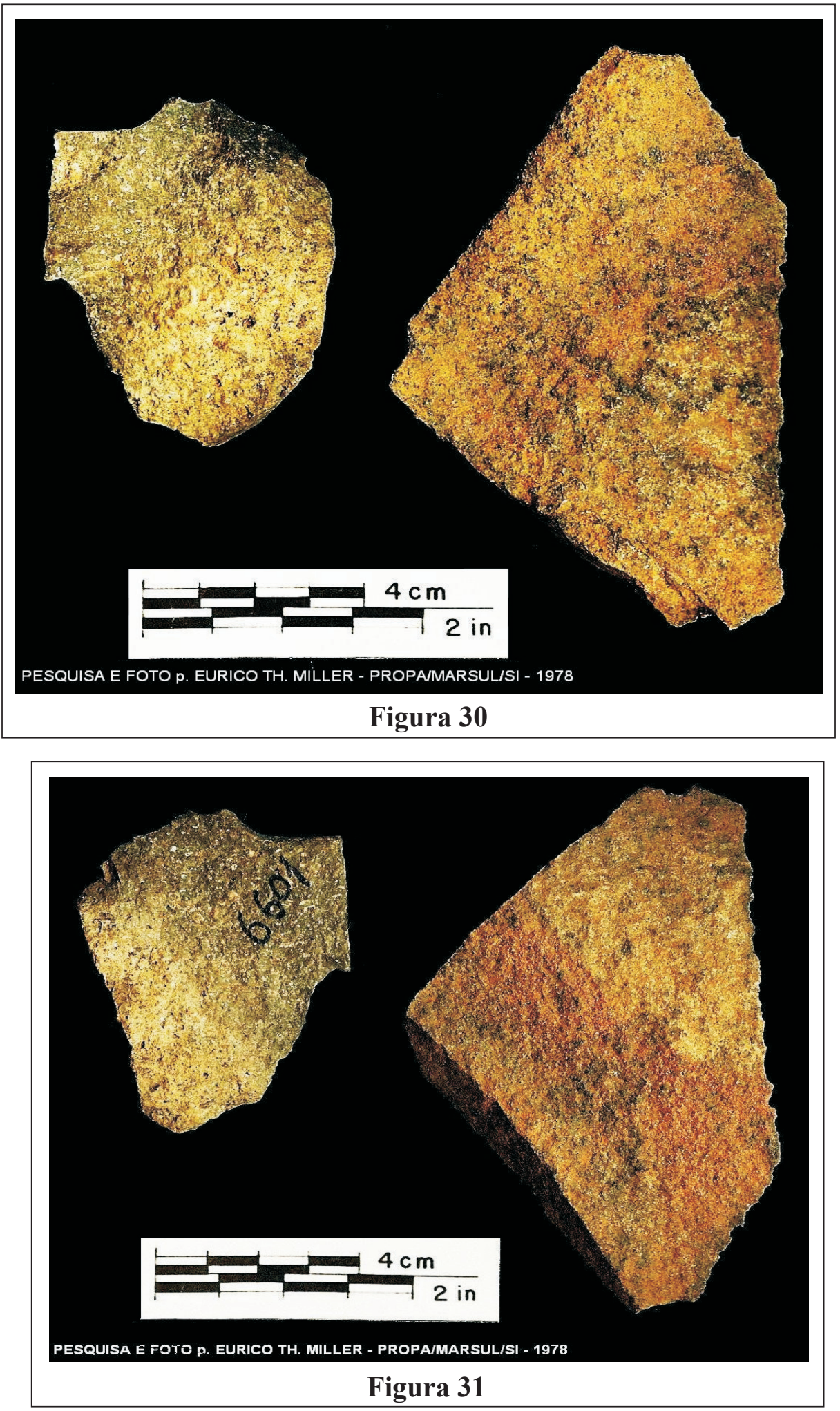

Jul. 2009 | Vol. 1, n. 1 | Revista Brasileira de Linguística Antropológica | 

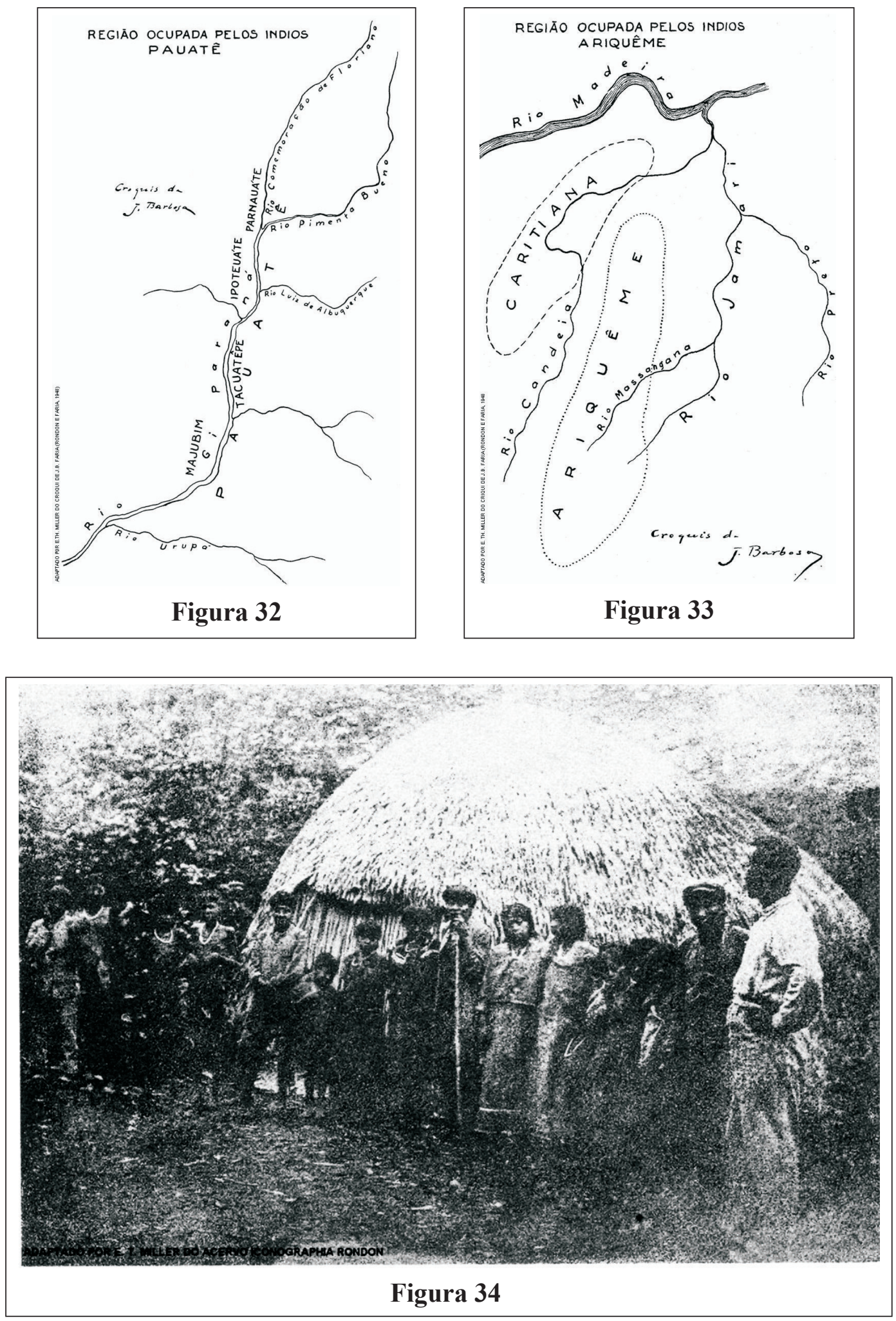